\title{
FEDERAL ASSISTANCE IN FINANCING MIDDLE-INCOME COOPERATIVE APARTMENTS
}

\author{
TABle of Contents
}

The Federal Program to Date . . . . . . . . . . . . 549

Background . . . . . . . . . . . . . . . . . . . . . 549

The Veterans Administration Program . . . . . . . . . 549

The First FHA Program . . . . . . . . . . . . . 551

The Adoption of Section 213 . . . . . . . . . . . . 552

The Federal Program Today . . . . . . . . . . . . 554

Section 213 . . . . . . . . . . . . . . . . . 554

Prerequisites . . . . . . . . . . . . . 554

The Mortgagee . . . . . . . . . . . . . 556

FNMA-A Supplement to Section 213 . . . . . . . . . . $55 \mathrm{~s}$

The Success of the Federal Program . . . . . . . . . . . 562

The Future: A Functional Analysis . . . . . . . . . . . 566

Lenders . . . . . . . . . . . . . . . . . 566

The Problem and 213's Answer . . . . . . . . . . . . 566

The Results . . . . . . . . . . . . . . . . . . 569

Two New Answers: More FNMA, Union Pension Funds . . . . . 573

Sponsors . . . . . . . . . . . . . . . . . . 581

Excessive Sponsor Profits and Self-Dealing . . . . . . . 584

The Courts' Approach . . . . . . . . . . . . . . . . $5 \$ 6$

The FHA's Approach . . . . . . . . . . . . . . . . 588

Cooperators . . . . . . . . . . . . . . . . . . . . 592

Financial Interdependence: A Key Disadvantage? . . . . . . . . 597

One Possible Answer: A Separate Fee for Each Unit . . . . . . 600

Still Another Answer: Assessment Insurance . . . . . . . . . 603

The Cooperator's Rights and Powers . . . . . . . . . . . . 606

Preventing Abuses by the Directors and the Cooperators . . . . 607

Sale of Individual Apartments . . . . . . . . . . . . 610

APPENDIX . . . . . . . . . . . . . . . . . . . 612 
Although less well publicized than the shortage of dwellings for low-income groups, ${ }^{1}$ the need for middle-income housing is probably more acute. ${ }^{2}$ On one side, the earnings of middle-income families-ranging roughly from $\$ 4,000$ to $\$ 7,000$ per year ${ }^{3}$-make them ineligible for government-subsidized public housing. ${ }^{4}$ On the other, the continued failure of private enterprise to

Citation forms used in this Comment for materials frequently cited are contained in the APPENDIX.

1. Since the most prominent means of alleviating that shortage has been low-rent public housing, 1955 House Hearings 153, 159, low-income housing needs are often identified with the public-housing shortage. See, e.g., Will 1958 Legislation Break Public Housing's Drcary Deadlock?, J. of Housing, May 1958, pp. 154, 155; Rapkin, Rent-Income RatioShould Formula for Public Housing be Changed?, id., Jan. 1957, p. 8. See also 50 Stat. SSS (1937), as amended, 42 U.S.C. $\$ 1402$ (Supp. V, 1958) (eligible parties for public housing must be of "low income" status). For an example of the publicity given to problems of public (and hence low-rent) as compared to middle-income housing, see $1957 \mathrm{In}$ $d c x$, J. of Housing, March 1958, pt. II, p. 919 (listing 40 articles on public, 18 on middleincome housing).

2. Voorhis, Middle Incone Housing: America's \#1 Housing Need, Proceedings, 1958 Cooperative Housing Conference 1; 1956 Senate Hearings 406-07 (chart) ; 1957 House Hearings 677 (statement of Wallace J. Campbell, Director, Cooperative League of the U.S.A.) ; 1958 Senate Hearings 692, 703 (statement of Philip F. Tripp, President, National Association of Housing and Redevelopment Officials). But see 1955 House Hearings 153, 159 (statement of Joseph S. Clark, Mayor of Philadelphia). Although existing before the war, see Hauser \& Jaffe, The Extent of the Housing Shortage, 12 Law \& Contearp. ProB. 3 (1947) (effect of the depression on the housing shortage), the middle-income housing shortage has increased greatly since that time. Blandford, Wanted: 12 Million New Houses, 34 Nat' Munic. Rev. 376 (1945) ; 1956 Senate Hearings 720, 722 (statement of Secretary, National Conference of Catholic Charities). See also 1957 Senate Hearings 858,862 (statement of N.Y. State Commissioner of Housing, illustrating methods for estimating a housing shortage).

3. Approximately $38 \%$ of the families in the United States have income within these limits. 1958 Senate Hearings 763. See NaT'L Housing Conference, 1957 Housing YearвоOK 63 [hereinafter cited as HousING YEARBOOK] ; 1957 Senate Hearings 939. Of course, classification as "middle income" varies considerably according to locality and size of the family. 1950 House Hearings 15-17; N.Y. Times, April 7, 1958, p. 1, col. 7, at 33, cols. 3-4. In New York a family, depending upon its size, may earn up to $\$ 10,000$ per year and still be classified within the middle-income group. Ibid.; 1957 Senate Hearings 787, 789 (statement of Ira S. Robbins, Chairman of the Board, National Housing Conference). Some authorities refuse to identify the middle-income group "technically," but simply include any family whose earnings are insufficient to purchase private housing yet high enough to make it ineligible for public housing. See ibid.; 1958 Senate Hearings 703. This definition of course creates an automatic shortage of middle-income housing.

The components of the middle-income group have been described as "The butcher, the baker, the candlestick maker.' They are the families of the average workingman-the clerks in the stores, the men who put the gasoline in your car, the neighborhood grocer, the rank and file of labor, the average young veteran." S. REP. No. 1286, 81st Cong., $2 \mathrm{~d}$ Sess. 49 (1950).

4. See Housing Squeeze an Workers, Business Week, Feb. 23, 1957, p. 75; Whyte, Arc Cities Un-American?, in 29 Reference Shelf 140 (No. 6, 1957); Grutzner, Income Limits Up For City Housing, N.Y. Times, March 12, 1958, p. 25, col. 2 (income limit for 
respond adequately to the demand for moderate-cost dwellings frustrates middle-income families in their search for suitable housing. ${ }^{5}$ Shut off completely from public and almost completely from private housing, these families must either resort to moderately priced but physically inadequate dwellings in slum areas, ${ }^{6}$ or forego other necessities and spend more than the standard one-fifth of their incomes for shelter. ${ }^{\top}$ Even the former alternative may be limited in this age of urban redevelopment programs $:^{8}$ torn-down slums are commonly replaced with housing priced beyond the means of the middle-income families who formerly lived in the redeveloped areas. ${ }^{9}$

federal housing in New York City, probably the highest housing-cost area, is $\$ 4000$ with an additional $\$ 100$ allowance for each child; state public-housing income limit for large families is $\$ 5,964)$. See Johnstone, The Federal Urban Renezual Program, 25 U. CHI. L. REv. 301, 334 (1958) (median income limit for eligibility for public housing in 1955 was $\$ 2,700$ ). See also 50 Stat. 888 (1937), as amended, 42 U.S.C. $\$ 1402$ (Supp. V, 1958) (statutory definition of public-housing eligibility requirements).

The City of New York has begun to develop middle-income public housing projects, but only a few are now available. Grutzner, supra. The earnings limit used to determine eligibility for such projects excludes the top half of the middle-income group. Compare ibid. (income limit on middle-income projects $\$ 7,490$ ) with N.Y. Times, note 3 supra (upper earning limit of middle-income families in New York is roughly $\$ 10,000$ ). Moreover, a normal eligible family might avoid public housing because of its tendency to attract "problem families." See Wood, The Problem Family: I, 1957 Housing Yenrbook 48; Colburn, The Problem Fanily: II, id. at 52.

5. The Cheapest Houses Available, 1957 Housing Yearbook 5; Staff of Senate Subcomar. on Housing of Comm. on Banking and Currency, 1957 Report, in 1957 Senate Hearings 334, 335; Housing Squeeze on Workers, Business Week, Feb. 23, 1957, p. 75; 1956 Senate Hearings 217, 218 (report on middle-income housing in New York State, Jan. 26, 1956) ; N.Y. Times, June 22, 1958, § \& (Real Estate), p. 1, col. \&, p. \&, col. 4.

6. See 1956 Senate Hearings 218.

7. See authorities cited note 5 supra. On the proportion of family income spent on housing, see Grebler, Blank \& Winnick, Capital Forahation in Residential Real Estate 124-33 (1956) ; N.Y. Times, June 1, 1958, 8 (Real Estate), p. 1, col. 1; 1958 Senate Hearings 763. On the trend toward a lower proportion of family income spent on housing, see Guttentag, Winnick's Case for a Changing Attitude Towa'd Housing, 70 Q.J. ECoN. 314 (1956) ; Winnick, Reply, id. at 319.

8. On the extent of the redevelopment program, see Johnstone, supra note 4 , at 301 ; Comment, 67 Y ALE L.J. 61, 63 nn.9-11, 91 n.135 (1957).

9. Johnstone, supra note 4 , at $321 \&$ n.113 (slums usually replaced by upper-income residences or commercial projects); Staff of Senate Subcoms. on Housing, op. cit. supra note 5. Congress, recognizing the effect of redevelopment on families living in the areas cleared, has tied the federal redevelopment program to the federal public-housing program : persons displaced by redevelopment programs and otherwise eligible have priority for public housing. 63 Stat. 423 (1949), as amended, 42 U.S.C. $\$ 1410$ (g) (Supp. V, 1958). See also 63 Stat. 631 (1954), as amended, 69 Stat. 638 (1955) (enactment and repeal of act which limited public housing to cities in which federally-assisted redevelopment projects were being carried out). Thus, the brunt of the relocation problems created by renewal programs often falls upon a large percentage of middle-income families formerly located in the redevelopment area and ineligible for public housing. 1956 Senatc Hearings 217,218 (report on middle-income housing in New York State, Jan. 26, 1956). See S. Rep. No. 1286, 81st Cong., 2d Sess. $48-49$ (1950). 
Responding to this need, Congress has attempted to encourage the private building of moderately priced dwelling units..$^{10} \mathrm{~A}$ key part of its legislation to date is found in title II of the National Housing Act, ${ }^{11}$ which provides for the federal insurance of mortgages on various types of housing. ${ }^{12}$ One portion of title II about which the legislators have expressed considerable optimism ${ }^{13}$ is the comparatively new section 213 program for the insurance of mortgages on cooperative housing. ${ }^{14}$ Although the program covers both cooperatively built single houses (sales projects) ${ }^{15}$ and cooperative apartments (management projects), the major emphasis has been on apartments. ${ }^{16}$

By encouraging the construction of these apartments, Congress has en-

10. Despite the fact that a serious housing shortage followed World War II, Congress failed to adopt a comprehensive scheme of housing legislation until 1950. See Robinson \& Weinstein, The Federal Government and Housing, 1952 WIs. L. REv. 581, 594-601.

11. $4 \$$ Stat. 1247 (1934), as amended, 12 U.S.C. $\$ \$ 1707-15(\mathrm{~s})$ (1.952), as amended, 12 U.S.C. $\$ \S 1709-11,1713,1715$ (c)-(e), (h), (j)-(s) (Supp. V, 1958). For a survey of the entire federal housing program, see Ewalt, Government In Housing and Home Finance, The "G.I." Loan, Savings and Loan News, Sept. 1957, p. 52; Ewalt, Fanny May and Its 3.6 Billion Portfolio, id., Oct. 1957, p. 49; Ewalt, The Federal Housing Administration, id., July 1957, p. 28.

12. Section 203, 12 U.S.C. $\$ 1709$ (1952), as amended, 12 U.S.C. $\S 1709$ (Supp. V, 1958), covers residential dwellings of four families or less; $\$ 207,12$ U.S.C. $\$ 1713$ (1952), as amended, 12 U.S.C. $\$ 1713$ (Supp. V, 1958),-rental housing; \$213, 12 U.S.C. \$ 1715(e) (1952), as amended, 12 U.S.C. $\$ 1715$ (e) (Supp. V, 1958),-cooperative housing; $\S 220$, 12 U.S.C. $\$ 1715$ (k) (Supp. V, 1958), -rehabilitation and neighborhood conservation housing projects; $\$ 221,12$ U.S.C. $\$ 1715$ (i) (Supp. V, 1958),-relocation housing.

For other suggested solutions to the middle-income housing problem, see 1958 Senate Hearings 286, 296 (statement of Richardson Dilworth, Mayor of Philadelphia) ; Colman, U.S. Housing Group Urges: (1) Greater Reliance on a Competitive Market Economy[;] (2) Greater Community Responsibility, Banking, Feb. 1954, p. 42.

13. See, e.g., H.R. Rep. No. 2363, S4th Cong., 2d Sess. 10 (1956) ; S. REP. No. 368, 85th Cong., 1st Sess. $4-5$ (1957) ; S. REP. No. 1448, 84th Cong., 2d Sess. 41 (1956).

14. 64 Stat. 54 (1950), as amended, 12 U.S.C. $\$ 1715$ (e) (1952), as amended, 12 U.S.C. $\S 1715$ (e) (Supp. V, 1958). Cooperative-apartment mortgage insurance is available only through the Government. One private company insures mortgages at a lower rate than the FHA; however, it has confined its activities to nonfarm properties accommodating eight or fewer families. See 1958 Senate Hearings 421 ; 1957 Senate Hearings 303 ; N.Y. Times, July 21, 1957, \& 8 (Real Estate), p. 1, col. \&.

15. In the sales-type project, individuals organize as a cooperative to finance and construct a group of single homes under a blanket mortgage. After completion of the project, the blanket mortgage is removed, and each member acquires title to a single home covered by an individual, insured mortgage. 64 Stat. 54 (1950), as amended, 12 U.S.C. $\$ 1.715$ (e) (a) (2) (Supp. V, 1958) ; 24 C.F.R. $\$ 243$ (Supp. 1958) ; FHA, Cooperative Housing Progralr 4, 5 (Pamphlet No. 3250, 1957). On the advantages of cooperatively-built homes, see N.Y. Times, July 29, 1958, \& 8 (Real Estate), p. 1, col. 8, p. 2, cols. 5-8.

16. See, e.g., Campbell, Progress in Cooperative Honsing, 1957 Housing YeareooK 32; 1950 Housc Hearings 221-35 (reply of Congressman Moulter to suggestion that $\$ 213$ be limited to sales-type cooperatives). "Apartment," as used here, has the same scope as "management projects" and includes garden apartments. See ProceEdrngs, 1958 CoOperaTIVE Housing Conference 65. 
dorsed one of the most complicated forms of land tenure. ${ }^{17} \mathrm{~A}$ cooperative is commonly defined in the self-contradictory terms of a building in which each tenant owns an apartment. ${ }^{18}$ More precisely, it is a multiunit dwelling for cooperators each of whom has, first, an interest in the entity owning the building and, second, a lease entitling him to occupy a particular apartment within the building. ${ }^{19}$ Typically, title to the entire property is held by a corporation ${ }^{20}$ organized under a business-corporation, ${ }^{21}$ nonprofit-corporation ${ }^{22}$ or

17. Yourman, Some Legal Aspects of Cooperative Housing, 12 LAW \& Contenrp. ProB. 126 (1947) (cooperative apartments involve "many legal problems foreign to the day-today practice of law") ; Hennessey, Co-Operative Apartments and Town Houses, 1956 ILL. L.F. 22, 26-27 ("naturally complex"). But see Flamm, Housing Co-operatives, 6 LAw. Gurd REv. 590, 593 (1946) ("The legal structure of an apartment co-operative is quite simple.").

18. See Issacs, To Buy or Not to Buy: That is the Question ... What is a Cooperatize Apartment?, 13 ReCORD of N.Y.C.B.A. 203, 207 (1958) ; Ennis, Coopcrative Housing, I, N.Y. Times, Dec. 22, 1957, §§ 8-9 (Real Estate), p. 1, cols. 5-6. Legal writers have noted the inaccuracy of this definition. See Issacs, supra at 207; McCullough, Co-operative Apartments in Illinois, 26 CHI.-KENT L. REv. 303, 321. (1948). The absence of a good definition of a cooperative apartment has also been noted. Issacs, supra at 204. For an awkward attempt, see Tompkins v. Hale, 172 Misc. 1071, 1073, 15 N.Y.S.2d 854, 857 (Sup. Ct. 1939), aff'd, 259 App. Div. 860, 20 N.Y.S.2d 398, aff'd, 284 N.Y. 675, 30 N.E.2d 721 (1940) ("a partnership for the mutual benefit of cooperative owners expressed in corporate terms").

19. See Note, 61 Harv. L. Rev. 1407, 1408 (1948). See generally FHA, Information and Forms on Cooperative Housing Under Section 213 of the National Housing ACT (Pamphlet No. 3251, 1956).

20. Teitelbaum, Representing the Purchaser of a Cooperative Apartment, 45 Ixx. B.J. 420, 421 (1957) ; Note, 61 HARv. L. Rev. 1407, 1408 (1948).

Most atthorities mention the trust form as a possible mode of operation. Hennessey, Co-operative Apartments and Tozen Honses, 1956 ILL. L.F. 22, 39; McCullough, Cooperative Apartments in Illinois, 26 CHI.-Kent L. Rev. 303, 307 (1948); Castle, Legal Phases of Cooperative Building, 2 So. CaL. L. REv. 1 (1928). And $\$ 213$ authorizes mortgage insurance for cooperatives organized as trusts, 64 Stat. 54 (1950), as amended, 12 U.S.C. $\$ 1715$ (e) (a) (1) (1952), as amended, 12 U.S.C. $\$ 1715$ (e) (a) (1) (Supp. V, 1958). For the disadvantages of trust organization, see Yourman, Some Legal Aspects of Cooperative Housing, 12 Law \& Contemp. Prob. 126, 128 (1947). Cf. Bryant v. Shaw, 190 App. Div. 578,180 N.Y. Supp. 301 (1920) (New York limitations on a business trust's power to hold land under N.Y. REAL Prop. LAW \$ 96).

The corporate form is, by far, the most popular, McCullough, supra at $307 \mathrm{n} .24,309$. Even in Illinois, where trust law is extremely flexible, see Breen v. Breen, 411 III. 206,103 N.E.2d 625 (1952), most cooperatives are organized as corporations. Teitelbaum, supra at 421 ; Hennessey, supra at 27. Co-ops have been organized as trusts in Cleveland, Ohio, however. Interview with Cleveland attorney, October 16, 1958.

21. Teitelbaum, supra note 20 , at 421 .

22. Yourman, supra note 20 , at 132 . Under the laws of many states, nonprofit corporations may not issue stock. Instead, certificates of membership are issued. BoYER, NoN Profit Corporation Statutes: A Critique and Proposal 156 (1957). References to stock in this Comment will be applicable also to nonprofit corporation membership certificates. 
cooperative-corporation act. ${ }^{23}$ Shares are issued to each cooperator in proportion to the relative value of the apartment he will occupy. ${ }^{24}$ Ownership of the stock entitles the member to a renewable proprietary lease which in turn entitles him to occupy a specific apartment. ${ }^{25}$ The scope of a cooperator's occupancy rights is set forth in his lease and the corporate by-laws. ${ }^{26}$

The cooperative apartment is usually financed through a mortgage, receipts from the sale of stock, and monthly assessments ("rent") levied against the shareholders. ${ }^{27}$ The mortgage on the property is executed by the title-holding corporation; occasionally, it is further secured by individual shareholder guarantees of those portions of the corporate debt corresponding to the shareholders' respective interests in the corporation. ${ }^{28}$ Funds received from the initial sale of stock provide equity capital and cover organizational expenses. ${ }^{29}$ The monthly assessment is determined by dividing the cost of amortization, interest, and upkeep among the cooperators in proportion to their stock ownership. ${ }^{30}$

Besides being unique in organizational structure, the cooperative has, until recently, been associated with unhappy business practices and unimpressive results. Historically, cooperative apartments in this country have occasioned fraud and financial instability, and have been an insignificant source of hous-

23. See cases cited note 273 infra. Cooperatives may also be organized under a state redevelopment law. See U.S. Bureau of Labor Statistics, Dep't of Labor, Buld. No. 896, Nonprofit Housing Projects in the United States 19 (1947) (East River Cooperative). The advantages and disadvantages of the various types of incorporation statutes are discussed in Yourman, stipra note 20, at 129-35.

24. See Issacs, sipra note 18 , at 203, 213-14 (discussing advantage of this method of stock allocation over allocation based on the number of rooms in the apartment).

25. Brett, Wyroff, Potter, Hamtlton, Inc., The Cooperative Apartarent House 10 (1957); Reeve, The Influence of the Metropolis on the Concepts, Rules and Institutions Relating to Property 197 (1954); Note, 61 Harv. L. Rev. 1407, 1408 (1948).

26. Hennessey, supra note 20, at 28; MacCenesney, The Princtples of Real Estate LAw 376 (1927). See FHA, Model Form of By-Lawes (For mortgagor corporation under $\S 213$ ) (Form No. 3244), and FHA, Model Form of Occupancy Agreement (Section 213) (Form No. 3237), reprinted in FHA, Information and Forms on Cooperative Housing Under Section 213 of the National Housing Act (Pamphlet No. 3251, 1956).

27. Although assessments are often called "rent," see In re Dunchian's Estate, 128 Misc. 511, 217 N.Y. Supp. 318 (Surr. Ct. 1926), they are not fixed but instead may be adjusted during the lease period to correspond with changing costs. See Hennessey, supra note 20 , at 41 (sample lease providing that two-thirds of the outstanding stock can change amount of the assessment).

28. See Hennessey, supra note 20, at 33; Yourman, supra note 20, at 132 (separate guarantees are usually not required by the mortgagee if government mortgage insurance is obtained). Absent individual guarantees, a deficiency judgment following foreclosure will lie only against the corporation. Teitelbaum, supra note 20 , at 420,421 .

29. Yourman, supra note 20 , at 126,132 .

30. United Housing Foundation, What Every Cooperator Should Know-A Guide to Cooperative Lrving, in 1954 Senate Hearings 976, 981; Anderson, Cooperative Apartments in Florida: A Legal Analysis, 12 U. Mrami L. Rev. 13, 17 (1957). See also Brets, Wyckoff, Potter, Hamilton, Inc., The Cooperative Apartment House 10 (1957) (listing costs considered in determining the assessment charge). 
ing. Although, following World War I, a severe housing shortage resulted in a cooperative-apartment "boom" and the establishment of co-ops in most major American cities, ${ }^{31}$ throughout the 1920's and early 1930's cooperative apartments constituted only a small portion of the total multiunit dwellings constructed. ${ }^{32}$ Moreover, cooperative apartments in this country-unlike those in Europe ${ }^{33}$-were used primarily to provide high-cost housing. ${ }^{34}$ Despite this feature of exclusiveness, the rate of mortgage foreclosures on cooperative apartments during the 1930's so far exceeded that for other types of dwellings that the co-op became known as the "orphan" of the Depression. ${ }^{35}$ Excessive mortgaging, ${ }^{36}$ exorbitant promoters' profits, ${ }^{37}$ and fraudulent management of the corporations owning the co-ops, ${ }^{38}$ were contributing causes of the widespread foreclosures.

31. Note, 61 Harv. L. Rev. 1407 (1948) ; Stockbridge, Ozm Your Orm Flat, 8 ANnals of Rear Estate PRActice 7, 8-10 (1926); Issacs, supra note 18, at 210. The first modern American co-op was constructed in New York City before the turn of this century. Id. at 207; ReEve, op. cit. supra note 25, at 189 n.7. But co-ops developed spasmodically until after World War I. Ibid.

32. During this period of peak cooperative growth, McCullough, supra note 20 , at 312 , $\$ 300$ million was invested in cooperatives in greater New York City, probably more than that invested in the rest of the country combined, see REEvE, op. cit. supra note 25, at 190 nn.9-10. Yet, even assuming a $\$ 600$ million investment, on the assumed basis of $\$ 6,000$ real capital investment per unit, see Lichtfield, Cooperative Apartments, 53 Architectural F. $313,322-30$ (1930) (extrapolations indicate that co-ops cost $\$ 10,000$ or more per unit to construct), cooperatives provided only 100,000 dwelling units-an insignificant portion of the 1.9 million multifamily units built between 1920 and 1933. 1957 Housing YeArbook 68 .

33. See authorities cited note 64 infra.

34. Fleishman, Collective Home Ozenership: A New Activity For Savings and Loan Associations, 13 J. LaNd \& P.U. ECoN. 411 (1937) ; 1950 Senate Hearings 232 (testimony that only 3 cooperatives built in New York City area during 1920-1930 period were middle-income). See also U.S. Bureau of Labor Statistics, Dep't of Labor, Bull. No. 896, Nonprofit Housing Projects in the United States (1947); Lichtfield, supra note 32, at 322-30. Co-ops were often "semi-hotels" in downtown residential areas. Taylor, Cooperative Ozenership To Meet the Present Shortage of Buildings, 33 ARChItECTURAL F. 31-32 (1920). Luxury co-ops are still popular. Hearings on S.I. Res. 38 and S. 1056 Before a Subcommittee of the Senate Committee on Banking and Currency, 85th Cong., 1st Sess. 31-32 (1957).

35. See 1950 House Hearings 232. Approximately $75 \%$ of the cooperatives failed. Note, 61 HARv. L. REv. 1407, 1410 \& n.25 (1948). See also McCullough, supra note 20, at 305 n.20 (listing co-op foreclosure cases). In contrast, during the worst of the Depression failures on residential mortgages were rarely as high as $20 \%$. See FIsHER, UrbaN ReAL Estate Markets: Characteristics and Financing 48 (1951); Fisher and Rapkin, The Mutual Mortgage Insurance Fund 91, 95, 96 (1956).

36. See, e.g., Schaffer v. 8100 Jefferson Ave. East Corp., 267 MIich. 437, 255 N.W. 324 (1934) (100\% mortgage); Postwar Co-ops, 88 ARCHItectural F. 93 (1948) (co-ops had dubious mortgage financing).

37. See Note, 61. HARv. L. Rev. 1407 (1948) (profits at times reached 100\%). Cf. Lichtifield, supra note 32 , at 315 (co-ops afford quick recoupment of profit).

38. See, e.g., Moses v. Boss, 72 F.2d 1005 (D.C. Cir. 1934) ; Seiders v. Henry, 347 I11. 467, 180 N.E. 462 (1932) ; Schaffer v. 8100 Jefferson Ave. East Corp., 267 Mich. 437, 255 N.W. 324 (1934) ; Abel v. Paterno, 153 Misc. 248, 274 N.Y. Supp. 749 (Sup. Ct. 1934), modified, 245 App. Div. 285, 281 N.Y. Supp. 58 (1.935); Anderson, supra note 30, at 14. 
The second major spurt of cooperative-apartment construction, like the first, ${ }^{39}$ developed as the result of a housing shortage. After World War II, cooperatives experienced a boom which has continued to date. ${ }^{40}$ During this period, the federal government has formulated its program for promoting cooperative apartments. In order to achieve its goal-easing the shortage of middle-income housing-the federal program must cope with legal complications flowing from the organizational structure of the cooperative, and with economic problems resulting from the fact that co-ops are comparatively unfamiliar to American builders and lenders, and to the public at large. ${ }^{41}$ This Comment will evaluate the performance of the federal program in the light of these necessities. It will analyze, first, the background, principal features, and impact of the program; and, second, the incentives and protection which the program accords the three parties most interested in the cooperative apartment: the lender, the sponsor, and the cooperator. The Comment will also propose certain regulatory changes designed to safeguard the individual cooperator's interest without deterring the participation of lenders and sponsors in the program.

\section{The Federal Program To Date}

\section{Background}

\section{The Veterans Administration Program}

The first specific authorization of federal aid to middle-income cooperative apartments was contained in a 1946 Veterans Administration (VA) regula-

39. See note 31 supra.

40. Parker, Cooperative Housing in the United States, Mid-1950, 73 Monthly Las. REv. 258, 259 (1951); Flexner, Cooperative Housing in the United States, Construction Rev., June 1958, p. 4.

During World War II and immediately afterward, co-ops became popular as a method of avoiding rent control. Marks \& Marks, Coercive Aspects of Housing Cooperatives, 42 ILL. L. KEv. 728 (1948). Restricted as to permissible rents, apartment owners found that it was more profitable to sell the individual units to tenants. An exorbitant price could be obtained because, if the tenant refused to purchase the apartment, it could be sold to outside parties. who could evict him as landlords desiring the premises for their own personal use. Ibid.; Richelieu Realty Co. v. Mangin, 187 Misc. 440, 63 N.Y.S.2d 381 (Sup. Ct. 1946). In 1945, the Office of Price Administration issued a regulation denying the statutory eviction remedy to stockholders who were not formerly tenants unless at least $80 \%$ of the converted co-op's stockholders were former tenants. See 10 Fed. Reg. 1973-74 (1945). A similar rule is presently in force under the Rent and Eviction Regulations, N.Y. UNconsol. LAws APr. $\$ 55$ (AcKinney 1953), of the New York Rent Control Act, N.Y. Uncorsor. Laws $\$ 8585$ (McKinney 1953). For the operative effect of this rule, see, e.g., Hoening v. McGoldrick, 281 A.pp. Div. 663, 117 N.Y.S.2d 535 (1952) ; Luxemberg v. Stichman, 208 Misc. 706, 144 N.Y.S.2d 296 (Sup. Ct.), rev'd, 2 App. Div. 2d 605, 157 N.Y.S.2d 395 (1956). Rent control also led to the conversion of rental apartments into cooperatives in England. Flats For Sale, 21 Soc. 139 (1954).

41. See 1949 House Hearings 35, 43; 1957 House Hearings 673; 22 FHA ANN. REP. 6 (1955). 
tion, number 36.4343, issued under the Servicemen's Readjustment Act.22 The act was, in effect, a middle-income housing bill, since so many veterans were at that time within the middle-income group. ${ }^{43}$ Although the regulation, which is still in force, extends the coverage of the Administration's mortgageguarantee program to include mortgages on cooperatives, it serves primarily. to illustrate the possible shortcomings of using mortgage insurance to encourage the development of cooperative apartments. From 1946 to 1958, the VA guaranteed mortgages on only 3,700 cooperative-apartment dwelling units. and most of the guarantees were issued prior to $1953 . .^{44}$ This failure of the VA program to take hold can be attributed to the illiberality of the guarantee provisions, and to administrative deficiencies within the VA.

The VA may guarantee a cooperative's mortgage obligation for up to sixty per cent of the underlying debt, provided the amount guaranteed does not exceed $\$ 7,500$ times the number of veteran-occupied units in the cooperative. ${ }^{45}$ Because, on default, the sum recouped through foreclosing a mortgage will, even in times of serious depression, ordinarily approximate at least sixty per cent of the principal obligation, ${ }^{46}$ the VA's guarantee has minimal value. Arguably, a sixty per cent guarantee would be desirable whenever the loan secured by the mortgage represents an abnormally high percentage of the

42. 11 Fed. Reg. 9701 (1946), as amended, 23 Fed. Reg. 2217 (1958). The National Housing Act, 48 Stat. 1246 (1934), as amended, 12 U.S.C. $\$ \S 1702$, 1738, 1743 (Supp. V, 1958) (sections covering multiunit rental projects) was in existence at that time and might have been used to insure cooperative apartment mortgages, but the FHA did not issue regulations authorizing such insurance. See Note, 61 HARv. L. KEv. 1407, 1413 n.42 (1948).

43. See 1950 VA AnN. REP. 94. The act was not designed as such, however. Edgerton, Adequate Private Home Credit-or Government Intervention, Savings \& Loan News, July 1955, p. 26 (the act was gesture of a grateful Government to a special class of individuals); Ewalt, Government In Honsing and Home Finance, The "G.I." Loan, id., Sept. 1957, p. 52 (not a housing bill, but product of high-hearted idealism) ; 1957 Housc Hearings 244-45. And, in 1957, over 20\% of the VA-financed homes cost in excess of $\$ 20,000$-far beyond the reach of a middle-income family. 1957 VA ANN. REP. 93.

44. Letter from P. N. Brownstein, Director, Loan Guaranty Service, Veterans Administration, to the Yale Law Journal, Sept. 5, 1958, on file in Yale Law Library. See 1950 VA ANN. REP. 95 (reporting progress to 1950). In April 1958, the act's loan-guaranty program for World War II veterans was extended two years until July 1960 . Act of April 1, 1958, § 6, 72 Stat. 73.

45. 64 Stat. 75 (1951), as amended, 38 U.S.C. $\$ 694$ a (1952), 38 C.F.R. $\$ 36.4343$, as amended, 23 Fed. Reg. 2217 (1958); 1957 VA ANn. Rep. 90; 1956 VA AnN. Rep. 109. "The VA's liability, as a guarantor of a loan is limited to that amount which has the same percentage relationship to the unpaid indebtedness that the original amount of guaranty bore to the original amount of the loan." Ibid. The VA also insures mortgages. "For each loan insured, the lender receives an insurance credit of $15 \%$ of the total amount ... but not in excess of $\$ 4,000$. Lenders are insured for all losses on such loans up to the aggregate amount of insurance credit on all insured loans made." 1957 VA ANN. REP. 90 . The insurance provision is used primarily on business loans, however. Id. at 93; 1954 VA ANs. REP. 94.

46. See Fisher \& Rapkin, The Mutual Mortgage Insurance Fund 92-104 (1956) (tables 27-37) (loss rates in disposal of foreclosed property rarely reached $30 \%$ of the loan amount even during the 1930 's). 
property's value-say ninety or ninety-five per cent-inasmuch as foreclosing a mortgage in such a situation can yield less than sixty per cent of the total loan. ${ }^{47}$ But the VA also restricts every guarantee by so many dollars per dwelling unit-currently $\$ 7,500 ;{ }^{48}$ in the past, less. ${ }^{49}$ Since the minimum cost of a cooperative-apartment dwelling unit has usually been about twice as much as the then current VA dollar limit, ${ }^{50}$ a guarantee which conformed to that limit could only make the guarantor liable for about half of a near one hundred per cent mortgage. Manifestly, half is less than sixty per cent.

Unfamiliar with the financing of large-scale projects, ${ }^{51}$ the VA has done little to offset the inadequacy of the statutory guarantee provisions. In fact, under the VA regulation, every instrument executed in connection with guaranteeing a mortgage on a cooperative apartment must be approved by the central VA office. ${ }^{52}$ Sample forms have been issued, but they are designed primarily for apartments of six units or less. ${ }^{53}$ Hence, every large cooperative apartment would require individual treatment by an office possibly far distant from the cooperative's locale. The regulation further discourages its use by stating as a general rule that mortgages on cooperative apartments of over 500 units will not be guaranteed unless the applicant can show special need. ${ }^{54}$ Not surprisingly, excessive red tape has tended to undermine Regulation 36.4343 .

\section{The First FHA Program}

In 1948, labor, war-veteran, and social-service pressure groups strove to salvage (among other things) the cooperative-housing provision of the doomed

47. The less-than-30\% rate of loss on foreclosures during the 1930 's, see note 46 supra, was partially attributable to the low loan-to-value ratio of the mortgages at that time, see Fisher, Urban Real Estate Markets: Characteristics and Frnancing 63 (1957) (indicating average ratio was in 40th percentile).

48. 64 Stat. 75 (1950), as amended, 38 U.S.C. $\$ 694 a$ (1.952).

49. 59 Stat. $626(1945)(\$ 4,000)$.

50. For approximations of the cost of a co-op as compared to the VA limit, see 21 FHA ANN. REP. 120 (1954) (average FHA-insured mortgage on new homes during 1949 and 1950 was approximately $\$ 8,000$; the VA limit at that time was $\$ 4,000)$; 1958 Sentate Hearings 95 (average price of house in 1957 was $\$ 15,000$ to $\$ 17,500$ in major cities; VIA mortgage limit at that time was $\$ 7,500$ ). Cooperative apartments are located primarily in one of the highest construction cost areas-New York-, see text at note 160 infra, so that the "average" figures cited above are probably lower than average as they apply to co-ops. But see note 326 infra, indicating co-ops run at least $10 \%$ lower in cost than single homes in the same area.

51. See notes $42-44$ supra and accompanying text. The only loans on multifamily dwellings guaranteed by the VA are those issued in connection with Regulation $36.4343,38$ C.F.R. $\$ 36.4343$, as amended, 23 Fed. Reg. 2217 (1958).

52. Regulation 36.4343, supra note 51; V'A, Multrple Unit Housrng Release, p. 2, $\S \S 3(\mathrm{~d})$, (f) (Oct. 1, 1954).

53. See, e.g., VA Form 4-6310b; VA Form 4-6310c; VA Form 4-6354.

54. "No such project... may be approved ... unless it is conclusively shown ... that a greater number of [units] . . . will assure substantial advantages to the veteran- 
Taft-Ellender-Wagner Bill. ${ }^{55}$ Congress responded by amending section 207 of the National Housing Act-the basic provision for mortgage insurance on middle-income rental apartments-to authorize the Federal Housing Administration (FHA) to insure mortgages on cooperative apartments. ${ }^{50}$ The amended 207 partially avoided the restrictions impeding the VA program. Insurance was granted for one hundred per cent of the loan amount (not sixty per cent as under Regulation 36.4343 ), provided the total mortgage did not exceed $\$ 8,100$ per unit (a marked improvement over the VA program which at that time had a $\$ 4,000$-per-unit limit)..$^{57}$ Nonetheless, administrative deficiencies were rife, and the FHA accomplished less than the VA. Having no previous experience with, and possibly hostile to, ${ }^{\text {ws }}$ cooperativeapartment projects, the FHA failed to issue specific regulations or to establish special procedures for approving the authorized mortgage insurance. ${ }^{59}$ As a result, section 207 was rarely utilized. ${ }^{60}$

\section{The Adoption of Section 213}

By the middle of 1949 , the supporters of cooperative housing were protesting against both the ineffective administration and the basic provisions of section $207 .{ }^{61}$ With the support of the President, ${ }^{62}$ they urged adoption of a bill which would authorize direct federal lending to cooperatives: a specially organized federal corporation of mixed private and government ownership would sell bonds and use the receipts for loans to cooperatives. ${ }^{63}$ In effect, the proposal would have instituted methods similar to those used in the

participants which could not be achieved in a smaller project." Regulation $36.4343,38$ C.F.R. \$ 36.4343, as amended, 23 Fed. Reg. 2217 (1958).

55. For the then apparent unlikelihood that the Taft-Ellender-Wagner Bill would pass, see 1957 House Hearings 36, 504-06 (statements of Representatives Spence and Wolcott on congressional attitude toward the bill).

The co-op provision of the bill is found at 1948 Senate Hearings 71. For examples of its supporters, see 1948 Honse Hearings 494-95 (American Veterans Committee); id. at 1092 (CIO); id. at 585 (National Conference of Catholic Charities).

56. 62 Stat. 1209 (1948).

57. 62 Stat. 1274 (1948).

58. Robinson \& Weinstein, The Federal Government and Housing, 1952 WIS. L. REv. 518, 600; 1949 House Hearings 300 (showing unfavorable attitude). But see 1949 House Hearings 28, 37, 43 (statement of Raymond M. Foley, Housing and Home Finance Administrator, that FHIA made every effort to ensure the success of the $\$ 207$ co-op program).

59. Parker, supra note 40, at 264.

60. Parker, supra note 40 , at 261 (only 2 projects had used $\$ 207$ co-op insurance prior to 1950 ); $i d$. at 264 ; 1950 House Hearings 371 .

61. See, e.g., 1949 Honse Hearings 182, 226, 477.

62. 1950 U.S. Code Cong. Serv. 1279, 1284 (President Truman's State of the Union Message, Jan. 4, 1950).

63. S. Rep. No. 1286, 81st Cong., $2 d$ Sess. 47 (1950). Originally, the bill proposed direct loans which would be financed by receipts from the sale of notes to the Treasury. S. Rep. No. 892, 81st Cong., 1st Sess. 46 (1947). 
various European countries where cooperatives have proved an especially effective means of reducing the shortage of middle-income housing. ${ }^{64}$ But, despite their success abroad, direct government loans were fiercely opposed in this country by institutional lenders ${ }^{65}$ and congressmen fearful of "socialism." ${ }^{66}$ After considerable debate, ${ }^{67}$ Congress settled on what was termed a compromise solution--section 213 of the National Housing Act. ${ }^{68}$.

For the supporters of cooperatives, section 213 may have seemed more of a defeat than a compromise. Its enactment firmly established the policy that federal aid to middle-income co-ops would be limited to mortgage insurance, that is, to the encouragement of private lending. ${ }^{69}$ Moreover, the terms of section 213 were only slightly more liberal than those of $207 .{ }^{70}$ Neverthe-

64. Low-cost co-ops have been used in Denmark, Finland, France, Germany, Great Britain, Holland, Italy, Spain, Sweden, and Switzerland. McCullough, supra note 20, at 304 ; Johnson, Scandinavians Expand State Housing Aids, 1957 Housing Yearbook 29; Senate Subcommittee Investigating and Studying European Housing Programs, Committee on Banking and Currency, Cooperative Housing in Europe, S. Doc. No. 148, 81st Cong., 2d Sess. 1-112 (1950). Direct government financial aid is common, particularly in the Scandinavian countries. Johnson, supra; S. Doc. No. 148, supra; Flexner, supra note 40 , at 4. And cooperatives constitute from 15 to $35 \%$ of the urban housing in those countries. S. Doc. No. 148, supra at $18,57,101$. Russia has also been promoting cooperative apartments. Frankel, Soviet Pronotes Prizate Building, N.Y. Times, Aug. 3, 1957, p. 4, col. 2.

65. 1950 House Hearings 201, 202-04 (statement of Oscar R. Kreutz, Executive Manager, National Savings and Loan League), 296 (statement of William A. Reckman, Chairman, Subcommittee on Mortgage Financing and Uiban Housing of the Committee on Federal Legislation of The American Bankers Association), 305, 306-07 (statement of George L. Bliss, Chairman, Legislative Committee, United States Savings and Loan League), 314 (statement of Dr. James J. O'Leary, Director of Investment Research of The Life Insurance Association of America). The self-interest and inconsistency of the lenders' approach to this bill is discussed in Robinson \& Weinstein, silpra note 58, at 587.

Direct loans for housing were not a new idea; they are presently available under the VA program in certain circumstances. Hearings on Bills Relating to the Loan Programs Administered by The Veterans Administration Beforc the House Committee on Veterans' Affairs, 85th Cong., 1st Sess. 39-40 (1957).

66. See, e.g., 96 Cong. Rec. 3836 (1950) (statement of Representative Leonard Hall that the proposed housing bill constituted "another long step down the road to socialism"), id. at 3878 ( similar statement by Representative Madden), id. at 3863 (reference to remarks of Representative Wolcott). See also 19,50 House Hearings 450.

67. See 96 Cong. Rec. 3352-91, 3822-78.

68. 64 Stat. 54 (1950). The compromise nature of this section has often been emphasized. Robinson \& Weinstein, supra note 58, at 600; Proceedings, 1958 Cooperative Housing Conference 23, 29. The provision for direct government loans was defeated by the narrow margin of 43-38 in the Senate. 96 CoNg. Rec. 3855 (1950). In the House, however, it met considerable opposition, see $i d$. at 3814-81, and was defeated by 218 votes to 155 , id. at 3881 .

69. Yearly attempts to pass a revised version of the 1950 bill have been unsuccessful. See, e.g., S. 2938, reprinted in 1954 Senate Hcarings 3-38; S. 1694, reprinted in 1957 Senate Hearings 15 ; 1956 Senate Hearings 9, 332, 462, 590.

70. See 1949 Senate Hearings 182. Section 213 increased the loan-to-value ratio of eligible mortgages - an unimportant change since co-op mortgages rarely are in danger of 
less, the adoption of section 213 in 1950 proved an important factor in stimulating the development of middle-income cooperative apartments. Presumably because the section represented serious congressional attention to the cooperative program, ${ }^{71}$ and because it specifically authorized the FHA to furnish technological aid and advice to insurance applicants, ${ }^{72}$ that Administration immediately issued regulations governing section 213 mortgage insurance. ${ }^{73}$ At that point, the federal program finally began to take effect.

\section{Section 213}

\section{The Federal Program Today}

Prerequisites. Although section 213 has been amended almost annually since $1950,{ }^{74}$ the program remains essentially the same as under the original enactment. ${ }^{75}$ The present statute and regulations authorize the FHA to insure fully certain mortgages covering cooperative apartments of eight units or more $;^{76}$ the annual charge for the insurance is 0.5 per cent of that year's aver-

exceeding that ratio. See note 187 infra. The new statute also changed the standard for evaluating mortgages from value to replacement cost-a change which later became significant when the FHA adopted different procedures for determining replacement cost and value. See text at notes 146-56 infra. Except for the change noted in the text accompanying note 72 infra, these were the only significant changes. See Robinson \& Weinstein, supra note 58 , at 600 .

71. "Because of the importance of cooperatives in the mortgage insurance program, ... [we] would establish a new section 213 of the National Housing Act . . . " S. REP. No. 892, 81st Cong., 1st Sess. 6 (1949).

72. 64 Stat. 56 (1950), as amended, 12 U.S.C. $\$ 1715$ (f) (Supp. V, 1958).

73. Section 213 was enacted on April 20, 1950. 64 Stat. 54 (1950). Regulations were promulgated shortly thereafter. 15 Fed. Reg. 2669, 4715, 4941, 6826 (1950).

74. 65 Stat. 648 (1951), 67 Stat. 123 (1953), 68 Stat. 595 (1954), 69 Stat. 635 (1955), 70 Stat. 1093 (1956), 71. Stat. 297 (1957).

75. And the $\$ 213$ program is likely to retain its present basic prerequisites for mortgage insurance. The 1958 Housing Bill, which was defeated in the late stages of the 84 th Congress, 104 Cong. REc. 16811-12 (daily ed. Aug. 18, 1958), contained no changes except that it increased the maximum ratio of principal obligation to replacement value in nonveteran projects by $3 \%$, and increased the maximum per-unit limitation by $\$ 250$, see note 80 infra. S. 4035, 85th Cong., 2d Sess. § 105 (1958) ; 104 Cong. Rec. 16788-96 (daily ed. Aug. 18, 1958).

Supporters of $\S 213$ continue to seek certain additional federal assistance for cooperative apartments, including a requirement of a $2 \%$ working-capital fund, and extension of the insurance to cover buildings which are converted into cooperative apartments. 1958 Senate Hearings 585 (Cooperative League of the United States), 764 (AFI-CIO). Their major aim, however, is enactment of the original 1950 bill, which provided for direct government lending. Letter from the Cooperative League of the U.S.A. to the Yale Law Jour$m a l$, Aug. 28, 1958, on file in the Yale Law Library.

76. 69 Stat. 635 (1955), as amended, 12 U.S.C. \$ $1715 \mathrm{e}$ (d) (Supp. V, 1958) states that the insured co-op "may include eight or more family units." The FHA has interpreted the "may" as must. See FHA, Information and Forms on CoOperative Housing Under Section 213 of The National Housing Act, Summrary Statemient 1 (Pamphlet No. 3251, 1956) ; FHA, Cooperative Housing Program 6 (Pamphlet No. 3250, 1957). 
age unpaid mortgage balance. ${ }^{77}$ A mortgage is not insurable unless title to the co-op resides in a nonprofit corporation or trust which is owned by and provides housing for the cooperators. ${ }^{78}$ The term of the mortgage may not exceed forty years, the interest rate $41 / 2$ per cent. ${ }^{70}$ In addition, the principal obligation of the mortgage is limited to the lesser of $\$ 12,500,000$, ninety per cent of the estimated replacement cost of the project, or $\$ 2,250$ per room. ${ }^{80}$ When half or more of the members of a cooperative are war veterans, the last two limits are ninety-five per cent of the replacement cost, or $\$ 2,375$ per room, respectively. ${ }^{81}$ The per-room figure may also be raised in the discretion of the Commissioner of the FHA if the project is classified structurally as an elevator type, or is located in a high-cost area; but it may not be increased above $\$ 3,950 . .^{82}$ Of the three basic restrictions on the amount of an insurable mortgage, the per-room and percentage-of-replacement-cost are the most important. Only a multibuilding project is likely to involve more than $\$ 12,500$,000 . In that event, the absolute limit can be avoided through individual mortgages on each apartment building. ${ }^{83}$

Before becoming eligible for section 213 insurance, a cooperative must also obtain FHA approval with respect to its financial status ${ }^{84}$ and architectural plans, $^{85}$ its proposed mortgagee ${ }^{86}$ and schedule of assessments against the cooperators, ${ }^{87}$ and its operational and management arrangements. ${ }^{88}$ The FHA has helped to simplify the approval procedure by issuing specific mortgage-

77. 24 C.F.R. $\$ 242.2$ (Supp. 1958), incorporating 24 C.F.R. $\$ 233.2$ (Supp. 1958). The statute limits the maximum amount of the fee to $1 \%$, 64 Stat. 56 (1950), as amended, 12 U.S.C. $\S 1715$ e(e) (1952), incorporating 12 U.S.C. $\$ 1713$ (d) (1952); but $0.5 \%$ has been the established fee since the act's inception, 15 Fed. Reg. 2321 (1950).

78. 64 Stat. 54 (1950), as amended, 12 U.S.C. $\$ 1715$ (a) (1952); 24 C.F.R. $\$ 241.1$ (Supp. 1.958).

79. 64 Stat. 55 (1950), as amended, 12 U.S.C. $\S 1715 \mathrm{e}$ (d) (Supp. V, 1958). The maximum interest rate is set exclusive of the insurance premium. Ibid.

80. 64 Stat. 54 (1950), as amended, 12 U.S.C. $\$ \$ 1715$ e(b) (1), (2) (Supp. V, 1958). If the unit is composed of less than four rooms, the per-room maximum may be discarded in favor of an $\$ 8,100$ per-unit ceiling. Ibid.

81. 64 Stat. 54 (1950), as amended, 12 U.S.C. $\$ 1715$ (b) (2) (Supp. V, 1958). Veteran is defined in 24 C.F.R. $\S 241.1$ (c) (Supp. 1958).

82. This limit can only be reached if the project is veteran, classified as an elevatortype structure, and located in a high-cost area. See 64 Stat. 54 (1950), as amended, 12 U.S.C. $\$ 1715$ e(b) (2) (Supp. V, 1958).

83. See, e.g., Hearing Pursuant to S. Res. No. 229 Before the Senate Committee on Banking and Currency, 83d Cong., 2d Sess., pt. 2, at 1199 (1954) ; N.Y. Times, Dec. 1, 1957, \& 8 (Real Estate), p. 1, col. 8.

S4. See 24 C.F.R. $\$ 241.26$ (Supp. 1958). See also id. $\$ 241.29$ (regulating charges), id. $\$ 241.15$ (regulating order of payments), id. $\$ 241.14$ (regulating accruals).

85. See 24 C.F.R. $\$ 241.4$ (Supp. 1958).

S6. See 24 C.F.R. $\$ 241.39$ (Supp. 1958), incorporating $\$ \$ 221.1-.8$.

87. See 24 C.F.R. $\$ 241.29$ (Supp. 1958).

SS. See 24 C.F.R. $\$ 241.30$ (Supp. 1958). 
form, ${ }^{80}$ architectural ${ }^{80}$ and working-capital requirements, ${ }^{91}$ along with model by-laws, ${ }^{92}$ certificates of incorporation ${ }^{93}$ and occupancy agreements. ${ }^{94}$ It has thus eliminated most of the administrative difficulties which inhibited the section 207 program. And, unlike the VA under Regulation 36.4343 , the FHA has empowered its branch offices to process applications for insurance. ${ }^{05}$

Once insurance is issued, the FHA can enforce uniformly required covenants ${ }^{96}$ binding the cooperative to insure against fire, ${ }^{97}$ to prevent the creation of inferior or superior liens, ${ }^{98}$ and to abstain from filing any instrument which would restrict occupancy on the basis of race, color or creed.9. Sales, "rent," capital structure and methods of operation remain subject to FHA regulation until the mortgage is satisfied. ${ }^{100}$ The FHA's supervisory power is made effective through the initial requirement that the corporate charter provide for the "issuance of certain shares of special stock (or other evidence of a beneficial interest in the mortgagor) which . . . will enable the Commissioner in his discretion to exercise majority voting rights in the event of violation of a provision of the charter. . . ."101

The Mortgagee. Section 213 establishes alternative procedures by which the

89. See, e.g., FHA, State of Connecticut Mortgage (Form No. 4106-B, 1952). The FHA has mortgage forms for each state. Letter from Tom L. Davis, Acting Chief Counsel, Cooperative Housing Section, Legal Division, Federal Housing Administration, to the Yale Law Journal, Dec. 1, 1958, on file in the Yale Law Library. Any changes from the model form must have specific FHA approval. 24 C.F.R. $\$ 241.6$ (Supp. 1958).

90. See, e.g., FHA, Certified Survey and Surveyors Report (Form No. 2457, 1950). See also, FHA, Iegal ReQuirements in the Closing of Section 213 Manageanent and Sales Type Projects Involving Insurance Upon Completion 19-20 (Pamphlet No. 115630,1957 ) (listing zoning and building requirements).

91. 24 C.F.R. $\$ 241.26$ (Supp. 1958).

92. FHA Form No. 3244 (Nov. 1957).

93. FHA Form No. 3234 (Nov. 1957).

94. FHA Form No. 3237 (Nov. 1957).

95. As would be expected, the responses of the various offices to $\$ 213$ have varied. See 1958 Senate Hearings 582 (many officials reported antagonistic). The FHA has 75 insuring offices and 17 servicing offices. Hearings on Independent Offices Appropriations for 1958 Before a Subcommittee of the House Comnittee on Appropriations, 85th Cong., 1st Sess., pt. 2, at 1789-91 (1957).

96. Since it is not a party to the mortgage, the FHA must actually force a given mortgagee to enforce a particular covenant under the insurance contract. See 24 C.F.R. $\$ 242.5$, adopting \& 233.7 (Supp. 1958).

97. 24 C.F.R. $\$ 241.13$ (Supp. 1958).

98. 24 C.F.R. $\$ 241.12$ (Supp. 1958). This requirement is relaxed for mortgagors who are state, federal or municipal instrumentalities. Id. \$ 241.21.

99. 24 C.F.R. \& 241.16(a) (Supp. 1958). See also Shelley v. Kraemer, 334 U.S. 1 (1948).

100. See 24 C.F.R. $\S 241.30$ (Supp. 1958) (operations regulated); id. $\S 241.29$ (approval of occupancy charges, i.e., assessments, required) ; FHA, Model Form of By-Lazes for Mortgagor Corporation Under Section 213, Art. III(3) (c) (Form No. 3244, 1957) (approval of prospective cooperators required).

101. 24 C.F.R. § 241.23 (Supp. 1958). 
mortgagee can realize the benefits of the insurance. ${ }^{102}$ Both require that he demand immediate payment of the debt thirty days after a default. ${ }^{103}$ Following one procedure, he would then convey to the FHA his entire interest in the property arising under the mortgage, his claims against the mortgagor, any insurance policies on the mortgaged property, and any payments received in connection with the mortgage which were not applied in reduction of the debt. ${ }^{104}$ In return, the mortgagee would receive government-guaranteed $3 \mathrm{x} / 8$ per cent negotiable debentures having a face value equal to the unpaid principal of the mortgage ${ }^{105}$ plus miscellaneous amounts paid by the mortgagee on such items as insurance, less one per cent of the unpaid debt. (The one per cent deduction is designed to reimburse the FHA for its eventual costs in foreclosing.) Beside the debentures, the mortgagee would also receive a cer-

102. The procedures are specified in 55 Stat. 58 (1941), as amended, 12 U.S.C. $\S \S$ $1713(\mathrm{~g})-(\mathrm{p})$ (1952), which is incorporated into $\$ 213$ by 64 Stat. 56 (1950), as amended, 12 U.S.C. $\$ 1715 \mathrm{e}(\mathrm{e})$ (1952).

103. 55 Stat. 58 (1941), as amended, 12 U.S.C. $\S 1713(\mathrm{~g})$ (1952). FHA-approved mortgages contain acceleration clauses activated upon a default lasting 30 days. See FHA, State of Connecticut Mortgage (Form No. 4106-B, 1957); 12 U.S.C. $\$ 1713$ (g) (1952); Bank of Am. Nat'l Ass'ns v. Dames, 135 Misc. 391, 239 N.Y. Supp. 558 (Sup. Ct. 1930), 30 CoLusr. L. REv. 893 (discussing legal basis of acceleration principle). Such clauses are usually not self-operative, and the mortgagee may forego accelerating the debt if he so elects. See State of Comecticut Mortgage, supra; Graf v. Hope Bldg. Corp., 254 N.Y. 1, 171 N.E. SS4 (1930), 40 YaLE L.J. 141; Basse v. Gallegger, 7 Wis. 442 (1858). But the FHA may force the mortgagee to accelerate the debt. 24 C.F.R. $\$ 233.7$ (Supp. 1958).

The mortgagor's default is defined by the act as "the failure [for 30 days] of the mortgagor to make any payment due under . . . the terms of a mortgage insured under this section." 55 Stat. 58 (1941), 12 U.S.C. $\$ 1713(\mathrm{~g})$ (1952). Despite this specific provision, acceleration may be forbidden when a default involves an insignificant amount. $C f$. Lettieri v. Mistretta, 102 N.J. Eq. 1 (1927), 37 Yale L.J. 672 (1928). See 40 YaLE L.J. 141 (1930).

104. 52 Stat. 16 (1938), 12 U.S.C. $\$ 1713$ (g) (1952) ; 24 C.F.R. $\S 233.8$ (a) (1) (Supp. 1958). The broad terms in this provision enable it to encompass the mortgagee's rights to both the property and the debt-sometimes considered as being capable of separate transfer. See Stewart v. Crosby, 50 Me. 130 (1863).

105. 24 C.F.R. $\$ 242.5$ (Supp. 1958) incorporates 24 C.F.R. $\$ 233.9$ (Supp. 1958), which sets the interest rate on the debenture. The debenture rate varies according to the date of the mortgage issuance. The rate for mortgages issued since July 1,1958 is $31 / 8 \%$. FHA, Rental Housing Insurance 22 (Form No. 2012, June 12, 1958). Rates for insurance issued before July 1, 1958 were as follows:

\begin{tabular}{|c|c|c|}
\hline Per Cent & On or After & Prior to \\
\hline $2 \mathrm{I} / 2$ & Aug. 13, 1954 & - $\quad$ Jan. 1,1955 \\
\hline $25 / 8$ & Jan. 1,1955 & July 1,1955 \\
\hline $27 \%$ & July 1,1955 & July 1,1956 \\
\hline 3 & July 1,1956 & Jan. 1,1957 \\
\hline $3 \mathrm{I} / 4$ & Jan. 1,1957 & July 1,1957 \\
\hline $33 / 8$ & July $\quad 1,1957$ & Jan. 1,1958 \\
\hline $3 \pi / 2$ & Jan. 1,1958 & July 1,1958 \\
\hline
\end{tabular}

Source: Ibid. 
tificate of claim for an amount which "when added to the face value of the debenture ... [equals what] the mortgagee would have received if, on the date of the transfer ... the mortgagor had extinguished the mortgage indebtedness by payment in full. . . .'106 In effect, this amount represents repayment of the mortgagee's expense in transferring the property, the one per cent deducted in computing the debenture amount, and any prepayment charges which would at that time be due under a hypothetical payment in full by the mortgagor. Thus, were the certificate of claim honored, it would make the mortgagee more than whole. ${ }^{107}$ The certificate is not guaranteed, however, and is valid only against any amount received on the FHA's sale of property in excess of the face value of the debentures plus expenses incurred by the FHA. ${ }^{108}$

Under the alternative procedure, the mortgagee must convey to the FHA merchantable title in the cooperative, and assign to the FHA any claims acquired in connection with the mortgage. Title can be acquired either through foreclosure proceedings by the mortgagee or voluntary surrender by the mortgagor. ${ }^{109}$ In return for the title and the assignment, the mortgagee would receive debentures in an amount computed as under the first procedure, except that the one per cent deduction is not taken. The mortgagee would also receive a certificate of claim exactly like that obtained under the first procedure, with the additional inclusion of a "reasonable amount" for necessary expenses incurred in foreclosure.

\section{FNMA-A Supplement to Section 213}

The federal program of aid to middle-income cooperative apartments is based primarily on but not found solely within section 213. The operations of the Federal National Mortgage Association (FNMA), a federal corpora-

106. 64 Stat. 56 (1950), as amended, 12 U.S.C. $\$ 1715$ e(e) (Supp. V, 1958), incorporating 52 Stat. 19 (1938), as amended, 12 U.S.C. $\$ 1713$ (h) (Supp. V, 1958).

107. Prepayment charges are permitted by 24 C.F.R. $\$ 241.18$ (b) (Supp. 1958). One commentator apparently does not consider the prepayment charge to be included in the certificate of claim. See Note, 55 CoLun. L. Rev. 411, 413 (1955) ("a certificate of claim entitles ... [ the mortgagee] to reimbursement for the expenses incurred in connection with the foreclosure proceedings [meeting FHA requirements for collection]"). Yet, the statutory language quoted in the text indicates that the mortgagee is entitled to more than mere reimbursement. The object of the certificate of claim is not simply to make the mortgagee whole, but to put him in the same position he would have been had the mortgage been paid in full on the date of default-and this would include reimbursement of expenditures plus a prepayment charge.

108. 52 Stat. 18 (1938), as amended, 12 U.S.C. $\$ 1713$ (h) (Supp. V, 1958). Any excess realized on the sale above the amounts needed to reimburse the FHA and pay off the certificate of claim is retained by the Commissioner and credited to the Housing Insurance Fund. See 62 Stat. 1273 (1948), as amended, 12 U.S.C. $\$ 1715(\mathrm{~h})$ (1) (Supp. V, 1958).

109. 24 C.F.R. $\$ 242.5$ (Supp. 1958), incorporating 24 C.F.R. $\$ 233.8$ (2) (Supp. 195S). If the former method is used, the mortgagee might have to purchase title at a judicial or self-conducted sale. Note, 55 Col.uM. L. Rev. 411, 413 (1955). 
tion, are an important complement to the FHA's activities. 'Title III of the National Housing Act authorizes the FNMA to lend support to the mortgage market by purchasing and selling mortgages insured by the federal government. ${ }^{110}$ Accordingly, the FNMA has increased the amount of available mortgage credit by purchasing mortgages: original lenders are thus enabled to convert existing mortgages into cash which can be used for financing new projects. ${ }^{111}$ Although the FNMA has supported the market for section 213 mortgages since their inception, the scope of that support has been subject to such constant revision that any evaluation or description of present FNMA operations must begin with a review of past ones.

Upon the enactment of section 213 in 1950, mortgages insured thereunder were automatically included within the authorized FNMA portfolio.112 In 1951 , the FNMA was further authorized to advance up to $\$ 30$ million for the purchase of prospective section 213 mortgages; $; 13$ thus, a lender could enter into a contract for the sale of a cooperative-apartment mortgage before he actually made the loan. ${ }^{114}$ Thirty million dollars proved insufficient, however, as annual applications for FNMA advance commitments were over twice that amount. ${ }^{115}$

In 1954, Congress completely revised the FNMA by dividing it into its present two principal divisions. ${ }^{116}$ The secondary-market division may pur-

110. $4 \&$ Stat. 1252 (1934), as amended, 12 U.S.C. $\$ \$ 1716-23$ (d) (Supp. V, 1958).

111. See FNMA, Background and History of the Federal National Mortgage Association 2, 5 (April 30, 1955). See also H.R. Rep. No. 2963, 84th Cong., 2d Sess. 81-82 (1956) ; Ewalt, Fanny May and Its 3.6 Billion Portfolio, Savings and Loan News, Oct. 1957 , p. 49.

112. Section 301 of the National Housing Act, 62 Stat. 1275 (1948), as amended by 63 Stat. 576 (1949), authorizing FNMA purchase of Title II FHA-insured mortgages, automatically encompassed $\$ 213$ mortgages. The old $\$ 207$ program, supra note 56 , had also been included under the FNMA program. 62 Stat. 1275 (1948). Purchases were made at par. Ewalt, supra note 111, at 50-51. And the FNMA fee was limited to 1\%. 64 Stat. 57 (1950). No mortgagee could sell more than $50 \%$ of his mortgages to the FHA, however. 62 Stat. 1275 (1948).

113. 65 Stat. 699 (1951). The advance commitments were limited to $\$ 3.5$ million for projects in a single state. 65 Stat. 700 (1951). Advance commitments had been permitted prior to 1950 but were barred at that time. 64 Stat. 57 (1950). The 1951 exception was limited to co-ops; advance commitments on other types of housing mortgages were still prohibited.

114. See generally FNMA, Background and Hrstory of the Federal Nattonat Mortgage Association 25-30 (April 30, 1955).

115. 8 Housing \& Home Finance AgEncy ANn. Rep. 415 (1954) [hereinafter cited as H \& HFA ANn. REP.] ; see 1954 Senate Hearings 293. The advance-commitment authorization continued for four years, with the FNMA purchasing a full $\$ 30$ million of $\S 213$ mortgages. The complete authorization was never utilized in full, however, since some mortgages were not actually purchased because of the expiration and withdrawal of mortgage applications. $8 \mathrm{H} \& \mathrm{HFA}$ ANN. REP. 417 (1954).

116. 68 Stat. $615-19$ (1954), as amended, 12 U.S.C. $\$ \$ 1719-21$ (Supp. V, 1958). In addition to the secondary market and special assistance functions, the 1954 revision also authorized "Management and Liquidation functions to manage and liquidate the mortgage 
chase mortgages at market value-as contrasted with the pre-1954 policy of buying at par 117_from mortgagees who in turn purchase FNMIA stock equalling one to two per cent of the price of the mortgages sold.118 The special-assistance division is financed entirely by Treasury Department loans. Originally, they were used to purchase only those classes of mortgages which the President deemed in need of special support.119 Although the purchaseprice formula for such mortgages was not set by the 1954 legislation, it was assumed to be above the normal secondary-market price. ${ }^{120}$ Purchases under either the secondary-market or special-assistance program are limited to mortgages with a principal obligation of less than $\$ 15,000$ per dwelling unit covered.121

Because the President did not include section 213 mortgages under the special-assistance program for $1954,{ }^{122}$ they were purchased only at the going price through the FNMA's normal secondary-market operations that year. Congress responded by limiting the President's discretionary power and

portfolio of FNMA (acquired by purchase or which may be acquired pursuant to contracts entered into prior to November 1,1954 ) in an orderly manner, with a minimum of adverse effect upon the residential mortgage market and minimum loss to the Federal Government." FNMA, Background and History of the Federal Natronal Mortgage Association 15 (April 30, 1955).

117. On FNMA practice prior to 1954, see Ewalt, supra note 111 . On $\$ 304$, which authorizes secondary-market operations, see FNMA, REport and Financial Statement of the Secondary Market Operations 3-5 (1958) ; FNMA, Secondary Miarket OperiTIONS 1-8 (1957) ; 8 H \& HFA ANN. REP. 406-08 (1954). For criticism of the secondarymarket operations, see 1957 House Hearings $631 ; 1957$ Senate Hearings 328 . But sce 1958 Senate Hearings 97-98 (letter from J. S. Baughman, President, FNMIA, to Jacl Carter, Staff Director, Subcommittee on Housing of the Senate Committee on Banking and Currency, May 1, 1958). Although the FNMA must purchase mortgages under its secondary operations at approximately the market price, it cannot pay over $100 \%$ of the unpaid principal. 68 Stat. 613 (1954), as amended, 12 U.S.C. \$ 1717 (Supp. V, 1958).

118. 71 Stat. 298 (1957), 12 U.S.C. $\$ 1718$ (b) (Supp. V, 1958). The exact stock purchase requirement is left to the FNMA's discretion. Prior to 1957 , the minimum requirement was 3\%. See 68 Stat. 595 (1954). Supposedly, FNMA stock is sold for one-half of its true value. See 1958 Senate Hearings 105 . Dividends paid on the stock may vary up to a 5\% maximum, but were $2 \%$ in 1955 . FNMA, BACKgRound AND History OF THE FeDERAL. National Mortgage Association 19 n.32 (April 30, 1955).

119. See 68 Stat. 612 (1954), 12 U.S.C. $\$ 1716$. (Supp. V, 1958) ; \& H \& HFA ANN. REP. 412-13 (1954). In deciding what classes of mortgages should receive special FNMA assistance, the President was required to consider conditions affecting the building industry and the national economy as well as the mortgage market. Thus, housing policy was tied to fiscal and cyclical factors as well as social need. See 1957 Senate Hearings 426-27. See also Abrams, U.S. Housing: $A$ New Program, The New Leader, Jan. 13, 1958, \$ 2, p. 4 (federal housing program generally has "been reshaped by a lobby composed of builders and lenders . . . to suit their own interests").

120. 1954 Senate Hearings 278-80, 147-53. The FNMA was also authorized to charge whatever fees would enable it to break even on handling costs under the special-assistance program. 68 Stat. 617 (1954), as amended, 12 U.S.C. $\$ 1716$ (b) (Supp. V, 1958).

121. 68 Stat. 617 (1.954), as amended, 12 U.S.C. $\$ 1717$ (b) (Supp. IV, 1957).

122. 8 H \& HFA ANN. REP, 413 (1954). 
authorizing the FNMA to use the special-assistance program to make $\$ 50$ million of advance commitments for section 213 mortgages, provided no more than $\$ 5$ million was invested in a given state. ${ }^{123}$ Accordingly, the FNMA purchased section 213 mortgages at ninety-eight per cent of face value. ${ }^{124}$ In 1956, pressure groups induced Congress to direct the FNMA to buy at ninety-nine per cent ${ }^{125}$ and, in 1957 , the purchase price was raised to par, with service charges limited to $11 / 2$ per cent. ${ }^{126}$ At the same time, the portfolio limit was raised to $\$ 200$ million, the ten per cent per-state limitation being retained. ${ }^{127}$ Fifty million dollars of this amount was reserved for mortgages on those cooperatives sponsored by consumers rather than builders or other parties interested in construction profits. ${ }^{128}$

By early 1958, $\$ 45$ million of the funds available for consumer-project mortgages remained uncommitted. ${ }^{129}$ In contrast, less than $\$ 1$ million of the $\$ 150$ million authorized for nonconsumer-project mortgages was still available. ${ }^{130}$ Despite complaints about this latter shortage, ${ }^{131}$ the sponsors of the 1958 housing bill did not propose any increase in the FNMA's authorized portfolio..$^{132}$ On the other hand, the bill would have limited FNMA service charges to one per cent, raised the maximum amount of the obligation on an eligible mortgage to $\$ 17,500$ per unit covered, and extended the required purchase price of one hundred per cent for another year. ${ }^{133}$ Whatever its merits,

123. 69 Stat. 636 (1955), as amended, 12 U.S.C. $\S 1720$ (e) (Supp. IV, 1957).

124. S. Rep. No. 1448, 84th Cong., 2d Sess. 42 (1956). FNMA also charged a $1 \%$ filing fee and a $0.5 \%$ marketing fee which, along with the $2 \%$ discount, made the cost of an advance commitment $3 \% / 2 \%$. This is passed on to the consumer in the form of a higher down-payment. Thus, the value of special assistance was offset by an increase of the consumer's cost at the point where he could least afford it-the down-payment. See note 164 infra. See also H.R. Rep. No. 2963, 84th Cong., 2d Se'ss. 59 (1956).

125. 70 Stat. 1096 (1956), 12 U.S.C. § 1720 (b) (Supp. IV, 1957). The pressure groups had desired a requirement that purchases be at par. S. REP. No. 1448, 84th Cong., 2d Sess. 42 (1956) ; 1957 House Hearings 245-46.

126. 71. Stat. 298 (1957), 12 U.S.C. \$ 1720 (b) (Supp. V, 1958). Not more than onehalf of the fee could be collected at the time of commitment.

127. 71 Stat. 299 (1957), 12 U.S.C. $\$ 1720$ (e) (Supp. V, 1958).

128. Ibid.

129. S. REp. No. 1349,85 th Cong., 2 d Sess. 7 (1958).

130. Ibid. See N.Y. Times, Dec. 24, 1957, p. 1, col. 4 (illustrating difference in movement of funds under the nonconsumer and consumer divisions); Proceedings, 1958 Cooperative Housing Conference 34.

131. See 1957 House Hearings 630 (National Housing Conference); 1958 Senate Hearings 586 (Cooperative League). See also 1957 House Hearings 755.

132. An earlier draft of the Senate bill had recommended a $\$ 50$ million increase. S. 4035, 85th Cong., 2d Sess. tit. VII, \$ 701 (c) (as reported June 19, 1958). But the version which reached the House floor omitted that provision. See S. 4035, 85th Cong., $2 \mathrm{~d}$ Sess. tit. III, $\S 303$, in 104 CoNG. REC. 16791 (daily ed. Aug. 18, 1958). It did include, however, many spending measures not found in the earlier Senate bill. Compare S. 4035, tit. III, of June 19, supra, with S. 4035, tit. III, of Aug. 18, supra.

133. 104 Cong. Rec. 16791 (daily ed. Aug. 18, 1958). 
the bill was not reported out of the House rules committee. ${ }^{134}$ On a vote to suspend the rules, the bill received majority-but not the requisite two-thirds -support. ${ }^{135}$

The failure of the 1958 bill left the present FNMA cooperative program in a state of flux. With the expiration of the one hundred per cent requirements, the FNMA reduced its purchase price on cooperative apartment mortgages to ninety-nine per cent. ${ }^{136}$ Further reduction is to be expected ${ }^{137}$ pending the likely enactment of the 1958 bill in $1959 .{ }^{138}$ Less likely, however, is an increase in the $\$ 150$ million authorized for buying nonconsumer-project mortgages. ${ }^{139}$ Of course, the FNMA could make funds available by selling some of the section 213 mortgages it presently holds, but probably will not do so while the market for its low-yield co-op mortgages is poor. ${ }^{140}$ Alternatively, the President could allocate funds for the purchase of section 213 mortgages under the special-assistance program, but his action in 1954 and his opposition to the 1958 housing bill suggest he will not. ${ }^{141}$

\section{The Success of the Federal Program}

In 1950, cooperative apartments supplied, at most, 4,500 middle-income dwelling units. ${ }^{142}$ Since then, section 213 has been utilized for the production

134. Id. at 16796 .

135. Id. at 16811 .

136. Summary of FNMA release of Aug. 28, 1958, in P-H FEd. Aid to Financing II 47818 (1958).

137. "The objectives of continuing operations on a self-supporting basis and of reselling mortgages in appreciable quantities seem highly unlikely of attainment if FNMA is required by law to pay par for mortgages which are valued by the market at less than par, and if FNMA continues to be subject to the present statutory controls relating to fees and charges." Testimony of J.S. Baughman, President, FNMA, 1958 Senate Hearings 100. See also H.R. Rer. No. 2963, 84th Cong., 2d Sess. 59 (1956) (citing the "FNMA's policy of a substantial discount for mortgages purchased under their special assistance programs") ; Akin, The Mortgage Market and FNMA, 23 ApPRAISAL J. 421 (1955).

138. See text at note 135 supra. See also N.Y. Times, Nov. 8, 1958, p. 13, col. 3 (Senate Majority Leader Johnson's 10-point program includes a proposal for "a bold housing program").

139. Congress has consistently favored consumer-sponsored projects. See note 258 infra. So long as the FNMA authorization for this type of co-op is sufficient, little is likely to be done to aid nonconsumer-sponsored co-ops. See note 132 supra and accompanying text.

140. See House and Home, Sept. 1958, p. 59; N.Y. Times, Dec. 7, 1958, § \& (Real Estate), p. 1, col. 8.

141. The FNMA has stated that the President does not have the legal power to include co-op mortgages under that segment of the special-assistance program which operates under his directive, because FNMA support for co-op mortgages is already specifically provided for by $\S 305(\mathrm{e}) .1958$ Senate Hearings $583-84$. This view seems erroneous.

142. Parker, Cooperative Housing, Mid-1950, 73 Montmlx LAB. Rev. 258-59 (1951), estimated 4,412 cooperative apartment units as of mid-1950. This estimate was based on reports from 38 out of 44 cooperative housing associations; approximately one-fifth of the cooperative apartment projects included were not middle-income projects. The estimate is 
of 26,524 units costing approximately $\$ 258$ million. ${ }^{143}$ This 600 per cent increase is more than twenty times that for other nonfarm, residential housing between 1950 and 1958.144 Moreover, the FHA currently has outstanding insurance commitments on projects covering approximately 5,200 units and is considering applications for the construction of 3,500 more. ${ }^{145}$

The significance of the section 213 program is further magnified by the fact that unfortunate legislative tampering prevented a greater increase in middleincome cooperative apartments. In 1954, Congress changed the maximum restriction on the principal obligation of eligible mortgages from ninety per cent of estimated replacement cost to ninety per cent of value. ${ }^{146}$ At the time, the FHA assured legislators that the change was merely a technical revision and would not alter the effectiveness of section 213.147 But insurance applications for the following year decreased sharply and covered less than 600 units. $^{148}$ Although other factors undoubtedly contributed to the decrease, ${ }^{149}$

based on consumer-sponsored cooperatives, for middle-income cooperative apartments in 1950 were almost entirely consumer-sponsored. See U.S. BurEaU of Labor Statistics, Dep't of Labor, Bull. No. 896, Nonprofit Housing Projects in the United States 1 (1947).

143. 1958 Senate Hearings 581 (chart, as of April 1, 1958). Section 213 apartments are located in 13 states and the District of Columbia. Ibid. See also 1957 Senate Hearings 97.

144. The increase in total number of nonfarm, residential units since 1950 has been less than 25\%. By 1957, the number of residential units had increased by 7 million over the 37 million total in 1950. 1957 Senate Hearings 663 (chart). An estimated 1.1 million new units were added in 1958. Fowler, '58 Construction Sets U.S. Record, N.Y. Timcs, Jan. 4, 1959, \$ 8 (Real Estate), p. 1, col. \&, p. 2, col. 2.

145. As of April 1, 1958, the FHA had issued insurance commitments covering 9,000 units and was considering applications on 6,700 more. 1958 Senate Hearings 581 (chart). These figures included both management- and sales-type projects. Since approximately $58 \%$ of the $\$ 213$ projects of the past have been management-type (apartments), ibid., that percentage has been used in estimating the number of commitments and applications which concerned apartments.

146. 68 Stat. 595 (1954), as amended, 12 U.S.C. \& 1715(b) (Supp. V, 1958).

147. H.R. REP. No. 2363, 84th Cong., 2d Sess. 11 (1956). The purpose of the change apparently was to align the statutory terms of $\S 213$ with those of $\S 203$, which provides for mortgage insurance on single-family dwellings. See 1957 House Hearings 144-45 (testimony of Norman Mason, Commissioner, FHA). At present, most of the FHA programs use a value rather than a cost standard. Sections 203-b, 203-i, 220, 221, 603 use "appraised value"; $\S 207$ "estimated value"; $\$ \S 213,220,221$, 803-"estimated replacement costs"; $\S 227$ _ "actual cost"; $\$ 608$-necessary current cost" (as did old $\S 603$ ) ; and $\S 501-$ "reasonable value."

148. H.R. REP. No. 2963, 84th Cong., 2d Sess. 55 (1956).

149. Ibid. (requirement of cost-certification and lack of FNMA support also hurt co-ops).

During this year, FNMA was purchasing mortgages at market rather than par. See text at note 122 supra. The market was fairly firm, however, so the lack of FNMA support was not of great importance. See note 199 infra. Moreover, since most FNMA support has gone to cooperatively-built single homes rather than apartments, the sharp drop in co-op construction during the year the amendment was in effect could not be attributed to lack of FNMA support in any case. 
the change brought about by the amendment was critical, for the distinction between replacement cost and estimated value is substantial. ${ }^{150}$ The former is based primarily on current construction costs and closely approximates the actual price paid for a project, especially when a cost-plus construction contract is used. ${ }^{151}$ An estimation of value, on the other hand, involves future price changes as well as current costs and, as used in 1955, often resulted in estimates five to ten per cent lower than the then corresponding replacement costs. ${ }^{152}$ The resulting limitation on the insurable amount of a given mortgage forced a substantial increase in the amount of down-payment necessary to finance a cooperative. ${ }^{153}$ The increase proved excessive, for ready cash was not available ; ${ }^{154}$ and, after a year's experience, Congress re-enacted the replacement-value standard. ${ }^{155}$ By then, the production of cooperative apartments had probably been curtailed by 2,000 to 4,000 units. ${ }^{156}$

Despite the 600 per cent growth in cooperative apartments (and the fact that it would have been greater but for congressional negligence), section 213 cannot be considered a success. Although intended to furnish a partial solution to the middle-income housing problem, ${ }^{\mathbf{1 5 7}}$ the section has proved the

150. See 1955 Senate Hearings 212; 1955 House Hearings 261 (1954 statutory revision was the principal factor in bringing about stoppage of the program).

151. 1957 House Hearings 145 (testimony of FHA Commissioner). On the frequent use of cost-plus contracts under $\$ 213$, see text at notes 296-97 infra. See also 24 C.F.R. $\S 241.34$ (b) (Supp. 1958).

152. See, e.g., valuations listed on cooperatively-built single homes. 1957 House Hcarings 145 (chart). See also H.R. REP. No. 2363, 84th Cong., 2d Sess. 11. (1956); North, Multifamily Housing-Appraising Today's Cliff Dwellings, 23 ApPraIsal J. 7, 13 (1955) (illustrating an appraiser's distaste for the replacement-cost standard).

153. A $5 \%$ decrease in an apartment's valuation will result in a much greater than $5 \%$ increase in the down-payment. Assume a building costs $\$ 300,000$, contains 20 units, and is appraised on a replacement cost basis at its actual cost. If a $90 \%$ mortgage were obtained, each cooperator would have a down-payment of $\$ 1,500$. On the other hand, if the appraisal under a value standard were $5 \%$ below the replacement cost amount and the same $90 \%$ mortgage were obtained, the requisite down-payment would be $\$ 2,170$ - an increase in the amount of the down-payment of over $33 \mathrm{r} / 3 \%$. See generally H.R. REP. No. 2363, 84th Cong., 2d Sess. 11 (1956).

154. On the inability of middle-income cooperators to afford even minimum downpayments, see authorities cited note 164 infra.

155. 69 Stat. 635 (1955), 12 U.S.C. $\$ 1715$ (b) (2) (Supp. V, 1958).

156. In $1952,6,093$ management co-op units were produced under $\$ 213$ and in 1953 , 5,664 units. 1957 Senate Hearings 97 . The supply of mortgage money for 4\%/2\% FHA-insured mortgages from mid-1954 to mid-1955-the period the amendment was in effectwas moderately good. See H \& HFA, Housing IN THE Econony-1955, at 7; Ewalt, Govermment in Housing and Home Finance, The "G.I." Loan, Savings \& Loan News, Sept. 1957 , pp. 52, 55.

157. S. Rep. No. 1286, 81st Cong., 2d Sess. 49 (1950) ; 1950 House Hearings 15 (statement of Housing and Home Finance Agency); see N.Y. Times, Jan. 4, 1959, $\S 8$ (Real Estate), p. 1, col. 8, p. 2, col. 6 (eighteen $\$ 213$ co-ops containing 2,600 units are presently under construction in the New York City area and 32 more containing 4,600 units are presently in the planning stage). 
source of an insignificant fraction of all FHA-sponsored middle-income housing, ${ }^{158}$ and has accounted for less than one per cent of the total FHA and nonFHA middle-income housing starts since $1950 .{ }^{150}$ The section cannot be termed a complete failure, however, because of its effectiveness in greater New York City, where it has been an important element in the construction of middle-income dwelling units. ${ }^{160}$ Of the approximately 27,000 cooperative apartment units built under section 213 , some 23,000 have been in that city. ${ }^{161}$ This figure represents from ten to twenty per cent of the private middle-income housing erected there in recent years. ${ }^{162}$ Thus, in one significant area, the 213 program has fulfilled the congressional hopes which inspired its enactment.

158. Co-ops represent less than $2 \%$ of the total FHA-sponsored middle-income housing built during $\S 213$ 's existence. Between 1951 and 1957, over 1.4 million single homes were constructed with the aid of $\$ 203$ mortgage insurance. H \& HFA, Housing STATISTICS 12 (1957). See also Hearings on Independent Offices Appropriation for 1958 Before a Subcommittee of the House Committee on Appropriations, 85th Cong., 1st Sess. 1806 (1957). During the same period, $\S 213$ cooperative apartments contributed less than 25,000 units. 1957 Senate Hearings 97.

Section 213 does, however, rank third among the FHA programs. Proceedrngs, 1958 Cooperative Housing Confrenence 34. And, during the past two years, apartment construction under $\S 213$ has exceeded that under $\S 207$, which is the general section for insurance on rental-apartment mortgages. See 1957 Senate Hearings 666 (table); Why You Should Look Into Rental Housing, House and Home, April 1958, pp. 103, 105. See also S. REP. No. 1448, 84th Cong., 2d Sess. 17, 18 (1956).

159. The VA has insured mortgages on more middle-income units than the FHA. Compare authorities cited notes 43, 158 supra with 1957 Senate Hearings 159-65, 177; Hearings on Extension of VA Housing Laws Before the Honse Committee on Veterans' Affairs, 85th Cong., 2d Sess. 2511, Exhibit C (1958), and H \& HFA, Housing Statistics $8-9,11$ (1957). Thus, the percentage of $\S 213$ co-ops to the total of middle-income units produced since 1950 is less than half the percentage of $\$ 213$ co-ops to all FHA-sponsored middle-income homes built since 1950 (i.e., less than $1 \%$, see note 158 supra).

160. The housing shortage in New York City is particularly critical. 1957 Senate Hearings $862-63 ; 1956$ Senate Hearings 218 ; N.Y. Times, June 22, 1958, 88 (Real Estate), p. 1 , col. 8 .

161. 1958 Senate Hearings 581. See N.Y. Times, Dec. 8, 1957, \& 8 (Real Estate), p. 6, cols. $6,7$.

162. Since 1950, 104,000 middle-income apartment units have been privately built in New York City with federal or state aid. N.Y. Times, Oct. 26, 1958, \& 10 (Advertisement), p. 5, col. 1 (report of Mayor Wagner); id., March 2, 1958, \& \& (Real Estate), p. 1, col. 7 (90,000 units built with federal aid). This represents almost all middle-income apartment units built in that city; cost factors make construction without government aid too expensive. See 1956 Senate Hearings 218-19; N.Y. Times, June 22, 1958, § 8 (Real Estate), p. 8, cols. 1-3. Section 213 co-ops therefore represent approximately $20 \%$ of the middle-income apartment units constructed in New York since 1950. At the same time, however, up to 50,000 single- or two-family house units have been built. Ennis, City Leads Nation in Private Homes, N.Y. Times, Feb. 24, 1957, \& 8 (Real Estate), p. 1, col. 8. No exact figures on the cost of such units are available. Interview with New York real estate agents, Nov. 30, 1958. If they were all middle-income units (which is unlikely), the percentage of $\S 213$ co-op units to the total number of single-home and apartment middle-income units would be $10 \%$. 


\section{The Future: A Functional Analysis}

Whether significant cooperative undertakings will spread beyond the confines of New York City depends on the future activities of three groupslenders, sponsors, and consumers. Since each has a different interest, the achievements of the section 213 program will be a measure of how well it can accommodate all three.

\section{Lenders}

\section{The Problem and 213's Answer}

Before the advent of section 213, the most serious obstacle to the development of a middle-income cooperative apartment was the co-op's inability to obtain adequate mortgage financing. ${ }^{163}$ Because prospective purchasers of units in a given cooperative generally could not afford high down-payments, ${ }^{104}$ the amount which the co-op borrowed on the mortgage had to represent an unusually large percentage of the purchase price of the building. ${ }^{165}$ But state laws strictly limit banks, life insurance companies, savings and loan associations, and other financial institutions which lend on mortgages, the permissible loanable percentage of value usually being far below the eighty to ninety-

163. See 1950 House Hearings 146 (almost impossible barrier), 185 (insuperable problem); Parker, Cooperative Housing, Mid-1950, 73 Monthly LAB. Rev. 258, 263, 278 (1951); Staff of Subcomm. on Housing and Rents of Senate Comms. on Banking and Currency, 81st Cong., 2D Sess., Report on Domestic Cooperative Housing is (Comm. Print 1950) ; Note, 61. HARv. L. Rev. 1407, 1415 n.51 (1948). Uncertainty existed as to the scope of the factors which contributed to this failure. Compare Parker, supra at 264 (suggesting that banker ignorance of the cooperative method, unwillingness to depart from established financing patterns, and intolerance of the interracial makeup of cooperatives prompted failure to lend to co-ops) and Haar, Middle-Income Housing: The Cooperative Snare, 29 Land Econ. 289, 293 n.18 (1953), with 1949 House Hearings 340, 397 (bankers were not opposed to the cooperative principle) and 1950 House Hearings 146-50 (cooperatives failed to receive backing only because they were not organized on sound financial principles).

164. See 1949 House Hearings 355 (suggesting down-payment in excess of 5\% might discourage housing development); Ewalt, Government in Housing and Home Finance, The "G.I." Loan, Savings and Loan News, Sept. 1958, p. 52 (returning servicemen in particular could not afford a high down-payment); UNITEd Housrng Foundatton, What Every Cooperator Should Know-A Guide to Cooperative Housing (1954), reprinted in 1954 Senate Hearings 978 (high equity payments are desirable but cooperators can rarely afford them).

The shortage of capital was sharply illustrated. Cooperators sometimes had to borrow to meet even a minimum down-payment. See, e.g., REPORT on DoMrestic CoOpERatTve Housing, op. cit. supra note 163, at 16-19; 1954 Senate Hearings 981; Clearview Associates v. Clearview Gardens First Corp., 8 Misc. 2d 470, 479-80, 168 N.Y.S.2d 432, 442 (Sup. Ct. 1957) (corporation arranged for loans so cooperators could meet their down-payments). See also 1950 VA ANN. REP. 95 (more than $40 \%$ of the homes purchased with VA aid were financed without down-payments). Cooperators today are still unable to afford substantial down-payments. See Proceedrngs, 1958 Cooperative Housing Conference 24, 60.

165. See Report on Donestic Cooperattve Housing, op. cit. supra note 163, at \&-16; Nonprofit Housing Projects in the United States, op. cit. supra note 142, at 26; 
five per cent needed by the cooperatives. ${ }^{\mathbf{1 6 6}}$ Moreover, institutional lenders, whether subject to statutory percentage limitations or not, were generally wary of financing cooperative apartments. The extraordinary rate of defaults on high-priced co-ops during the 1930's had earned for every cooperative the reputation of an exceptionally risky investment. ${ }^{167}$

Section 213 has substantially eliminated both the statutory limitations and the risks involved in granting cooperatives high-percentage mortgages. Most states have enacted special legislation permitting financial institutions to exceed the statutory limits on the ratio of mortgage amount to value when the mortgage is insured by the FHA. ${ }^{168}$ In addition, the lender's risks are minimized by the facts that the insurance covers the entire obligation due, and that the loan can probably be recovered with greater facility under the insurance policy than under most state foreclosure procedures. ${ }^{169}$ Although a co-op mortgage default has not yet occurred under section $213,{ }^{170}$ experience under the other federal mortgage-insurance programs having similar prerequisites for collection indicates that the FHA is lenient in construing these prerequisites. ${ }^{171}$ For example, technical errors in the filing of the insurance application or in the servicing of the mortgage have not been utilized to deny claims for collection. ${ }^{172}$ Similarly, when a mortgagee claims insurance benefits by trans-

Flieshman, Collective Home Owmership; A New Activity for Savings and Loan Associations, 13 J. LAND \& P.U. EcoN. 411, 412 (1937) (90\% suggested); Parker, supra note 163 , at 263.

The high-cost co-ops of the 1920's tried to reduce the requisite cooperator equity investment by increasing the funded debt. Cf. Kibbe, Financing Cooperative Apartments, 53 ARchitectural F. 370 (1930).

166. See 1950 House Hearings $232 ; 1958$ Senate Hearings 423 (a two-thirds ratio is the normal limit).

167. 1949 Honse Hearings 396; 1950 House Hearings 222 (National Ass'n of Home Builders) ; Note, 61 HArv. L. Rev. 1407, 1412 n.30 (1948) (real estate boards and lending institutions are "agreed that only a small mortgage or the absence of one can assure success" of a co-op). Even in the 1920 's, lenders disliked co-op mortgages representing more than $40 \%$ of cost. Ibid. See also Kibbe, supra note 165 , at 370 (utmost conservatism needed in financing cooperatives).

168. 1958 Senate Hearings 423, see also 1957 Senate Hearings 521. In most instances, the special legislation had already been passed to accommodate other FHA programs, and the 1950 adoption of $\$ 213$ included that section within the general FHA exception to state limitations on loan amounts. See 1950 House Hearings 232.

169. See Edgerton, Adequate Private Home Credit-Or Government Intervention?, Savings \& Loan News, July 1955, pp. 26, 27 (complaining that with FHA insuring, the possibility of a lender suffering loss is so slight that he loses his perspective).

170. Letter from Jerry Voorhis, Executive Director of the Cooperative League of the U.S.A., to the Yale Law Joumal, Aug. 28, 1958, on file in Yale Law Library; N.X. Times, Dec. \&, 1957, \& 8 (Real Estate), p. 1, col. 7; FHA, Cooperative Housing Program 11 (Form No. 3250, 1957).

171. These other programs are under $\$ 207$, which has the same requirements, see note 102 supra, and $\S 203$, which provides that the mortgagor must transfer the land to the FHA prior to collection. See text at note 109 supra.

172. Neal, FHA Experience on Single Fanily Foreclosires, Banking, Dec. 1953, p. 47. 
ferring "marketable title" to the FHA, ${ }^{173}$ this term is defined in accordance with general conveyancing practices. ${ }^{174}$ In fact, the FHA has reduced insurance claims only in those situations in which the mortgaged property had been depleted through waste. ${ }^{175}$ And, even here, the mortgagee's normal risk that the insolvent mortgagor will be wasteful is limited, for the FHA deducts no more than $\$ 100$ per unit from the collectible insurance benefits on account of waste. ${ }^{176}$

Institutional lenders have nonetheless complained that all payments under an FHA insurance policy are made in guaranteed debentures rather than cash, ${ }^{177}$ despite the fact that the debentures yield interest-presently 3 I $/ \mathrm{s}$ per cent-and are ordinarily redeemed within a year after issuance. ${ }^{178}$ If the mortgagee does not wish to wait, he or his transferee may use the debentures to pay insurance premiums on other section 213 (or section 207) rental projects. ${ }^{179}$ Moreover, even with a possible year's delay, the mortgagee may

173. When the mortgagee collects insurance by the procedure of granting title to the FHA, 12 U.S.C. $\$ 1713(\mathrm{~g})$ (1952) (proviso), the title so conveyed must conform to requirements in force at the time the statute was issued. Ibid.

24 C.F.R. $\$ 233.9$ (c) (Supp. 1958) states that title will be satisfactory if it is "such title as was vested in the mortgagor as of the date the mortgage was filed for record," except for prior liens or other matters approved by the Commissioner. Thus, absent qualification under the exception, the title must be the same as at the date of recording-i.c., "marketable." 24 C.F.R. § 241.43 (Supp. 1958).

174. Neal, supra note 172 , at 48 .

175. Ibid.; Hearings on Independent Offices Appropriations for 1958 Beforc a Subcommittee of the House Committee on Appropriations, 85th Cong., 1st Sess., pt. 2, at 1773 (1957) ; Hearings on S. 2295, S. 3258, S. 3336, and S. 3373 Before the Senate Committec on Banking and Currency, 85th Cong., 2d Sess. 27 (1958).

176. Hearings on Independent Offices Appropriations for 1958, supra note 175, at 1773. This practice has been criticized by the General Accounting Office. See id. at 1774 .

Nonetheless, the mortgagee has a cause of action against the wasting mortgagor. Bryon v. Chapin, 113 Mass. 308 (1873) ; First Nat'1 Bank v. Sproull, 105 Ala. 275, 16 So. 879 (1894). The $\$ 100$ loss may still be preferable to pressing suit against a solvent mortgagor if, as in at least one state, the mortgagee is compelled to go beyond the prerequisites of 24 C.F.R. $\$ \$ 233.8(2)$-(11) (Supp. 1958), in order to obtain an action for wasteful conduct. That regulation merely requires that the mortgagee convey title to the FHA, but in Michigan he must also obtain a deficiency judgment. See, e.g., Taylor v. McConnel, 53 Mich. 587, 19 N.W. 196 (1884).

177. Stern, U.S. Acts to Spur House Ozonership, N.Y. Times, Jan. 12, 1958, \& 8 (Real Estate), p. 1, col. 8, p. 2, col. 6. See also 1956 Rep. of N.Y. Housing Coms'r 476 n.1.

178. See note 105 supra; Hearings on Independent Offices Appropriations for 1958, supra note 175 , at 1775 . The term is 20 years, however, and the FHA has no obligation to redeem the debentures before then. 24 C.F.R. $\$ 233.9(1)$ (v) (Supp. 1958).

179. The debentures cannot be used to pay premiums under other FHA programs. Section 203(c), 68 Stat. 121 (1.954), 12 U.S.C. $\$ 1709$ (c) (Supp. IV, 1957), provides "that debentures presented in payment of premium charges shall represent obligations of the particular insurance fund to which such premium charges are to be credited."

Section 207 and 213 debentures are obligations of the Housing Insurance Fund. Letter from Tom L. Davis, Acting Chief Counsel, Cooperative Housing Section, Legal Division, Federal Housing Administration, to the Yale Law Journal, Dec. 2, 1958, on file in Yale Law Library. 
often realize cash payment on an insured mortgage earlier than he would through foreclosure. By assigning to the FHA all his rights upon default, the mortgagee can obtain the debentures at once. ${ }^{180}$ On the other hand, if he forecloses, he may have to wait a year before the steps prerequisite to an authorized sale of the mortgaged property are completed. ${ }^{181}$ At that point, the property may still be subject to a six-month or one-year statutory right of redemption, with occupancy rights in the mortgagor. ${ }^{182}$ Consequently, the mortgagee may be forced to let the redemption period run before selling the property, lest its sale price be depressed by the mortgagor's outstanding rights. ${ }^{183}$ Thus, as compared to normal collection procedures, federal mortgage insurance subjects the lender to little delay in securing cash repayment following a default. ${ }^{184}$

\section{The Results}

Although facility of collection and the complete coverage of FHA mortgage insurance have eliminated almost all the risk in accepting a high-percentage mortgage on a cooperative apartment, loans are still practically unobtainable. ${ }^{185}$ With the exception of a few mutual savings banks, lending institutions remain almost as unfavorably disposed toward cooperative-apartment

180. 52 Stat. 18 (1938), as amended, 12 U.S.C. $\$ 1713(\mathrm{~g})$ (1952). See text at notes 108-08 supra.

181. Carey, Brabner-Smith \& Sullivan, Studies in Foreclosures in Cook Connty: II, Foreclosure Methods and Redemption, 27 ILL. L. REv. 595, 599 (1933). See also N.H. Rev. Stat. Ann. $\$ 479: 27$ (1955); Mrnn. Stat. Ann. $\$ 580.03$ (1946). For a survey of the statutory requirements, see Sherman, Mortgage and Real Estate Investment Guide (Aug. 1958 ed.).

182. Twenty-six states have statutory rights of redemption for a period in excess of 6 months; 15 vest possession in the mortgagor. SherMan, op. cit. supra note 181 (redemption provision listed under point no. 8 of state-by-state analysis). See, e.g., Saye v. Van der Voort, 200 Iowa 900, 205 N.W. 760 (1925).

183. The inability of the mortgagees to convey immediate legal possession of the property may reduce bids at a judicial or mortgagee's sale to an amount below market value, Oszorne, Mortgages 25 (1951); see Carey, Brabner-Smith \& Sullivan, supra note 181 , at 615 , or might result in no bids whatever. Durfee \& Doddridge, Redemption from Foreclosure Sale-The Uniform Mortgage Act, 23 Micr. L. Rvv. 825, 840 (1925). To gain the best possible recoupment in either instance, unless he is certain of collection after a deficiency judgment, the mortgagee must purchase the property and resell when the redemption expires.

184. Of course, if the mortgagor chooses to collect his insurance benefits under the procedure calling for an assignment of rights, he sacrifices $1 \%$ of the unpaid balance in lieu of foreclosure costs. In many states this is a bargain. See, e.g., estimated costs in Alabama, Alaska, California, Florida, Utah, Vermont, and Washington, listed in SHERMAN, op. cit. supra note 181 .

185. North, Appraising Today's Cliff Dwellings, 23 Appraisal J. 327, 332 (1955); 1957 U.S. Code Cong. \& Ad. News 1143; 1957 House Hearings 672; REPoRT of THE President's Aduisory Comaittee on Government Housing Polictes and Programs 41 (Dec. 1953); Co-op Activity \& Housing News, May 5, 1958, p. 8, col. 5. 
financing today as they were prior to the enactment of section 213 in $1950 .^{180}$ Furthermore, most of the mortgages which have been accepted are limited in amount to only slightly above eighty per cent of the replacement cost of the projects involved. ${ }^{187}$ Lending institutions advance two reasons for their continued parsimony.

The first is that cooperative-apartment financing is unfeasible because an adequate mortgage necessitates too long a term. ${ }^{188}$ The down-payment is so small and the mortgage so large that to spread payments on the indebtedness over a short term would be to put them beyond the means of the cooperators. ${ }^{189}$ For this reason, section 213 permits the amortization of an insured mortgage to continue for up to forty years. ${ }^{190}$ Although the useful life of an apartment building may be longer, ${ }^{191}$ lenders still balk at the statutorily authorized period of amortization. They argue that a long-term mortgage is subject to cyclical fluctuations which might cause the market value of the secured property to drop below the amount of the indebtedness. ${ }^{102}$ In one

186. See note 183 supra; 1957 House Hearings 672 . Although mutual savings banks do not ordinarily grant much original financing, they are the leading original financers of $\$ 213$ co-ops. See, e.g., 22 FHA Ann. Rep. 53 (1955); 21 id. at 73 (1954); 20 id. at 108 $(1953) ; 19 \mathrm{id}$. at $104(1952) ; 18 \mathrm{id}$. at 84 (1951). They presently hold approximately $70 \%$ of the $\$ 213$ cooperative apartment mortgages. $22 \mathrm{id}$. at 59 (1955). As mutuals, they are similar in organization to the cooperatives, 1948 House Hearings 896,$916 ; 1957$ Senate Hearings 468, and were strong supporters of cooperatives even before the enactment of $\S 213,1950$ House Hearings 301 . As bankers, however, they oppose taking mortgages on residences for a term of more than 30 years. 1948 House Hearings 912. Unfortunately for the development of cooperatives, the mutual savings banks are located primarily in New England. 1958 House Hearings 251. Life insurance companies, the leading lenders under other government housing programs, Gillies and Curtis, The Structure of Local Mortgagc Markets and Government Housing Finance Programs, 10 J. Fin. 363, 364-65 (1955), prefer loans with $5 \frac{1}{2} \%$ interest and comparatively short terms, see House \& Home, April 1958, pp. 104-05.

187. 21. FHA ANN. REP. 162 (1954) (80.7\% average); 22 id. at 167 (1955) (84.5\% average). See also United Housing Foundatton, What Every Cooperator Should Know-A Gutde to Cooperative Housing (1954), in 1954 Senate Hearings 978. Despite FHA insurance, lenders generally oppose loans in excess of $80 \%$. Edgerton, Adequate Private Home Credit-or Government Intervention, Savings \& Loan News, July 1955, pp. 26, 28. Even the mutual savings banks rarely give $90 \%$ loans. 1958 House Hearings $257,262$.

188. Interviews with savings and loan officials in Cleveland, Ohio, Aug. 26-Sept. 5, 1958; 1950 House Hearings 310-12. See Edgerton, supra note 187, at 28; 2957 Senate Hearings 386-87 (35-year amortization period opposed).

189. See authorities cited notes $3,6,16$ supra.

190. 64 Stat. 56 (1950), as amended, 12 U.S.C. $\$ 1715$ e(d) (Supp. V, 1958).

191. 1950 House Hearings 313; H.R. REP. No. 1686, 81st Cong., 2d Sess. 24 (1950). See also 1950 House Hearings 416 (amortization period in Europe extends up to 100 years); 1956 House Hearings 406.

192. 1950 House Hearings 310,312 . Lenders also argue that the long term increases the overall cost to the consumer. Edgerton, supra note 187, at 28; Marcus, Ten Rcasons for Merging FHA \& VA Functions, Banking, March 1957, p. 153. Their sincerity in raising this argument is questionable, because the increased costs come from greater lender 
respect, section 213's guarantee of one hundred per cent of the loan cures this deficiency. But, lenders contend, the increased possibility that the collateral will at some time be insufficient undeniably implies the likelihood of a mortgage default necessitating the costs of foreclosure and the administrative delays of collecting on the insurance. ${ }^{193}$ Theoretically sound, this latter argument is nonetheless open to question in view of the fact that, although an individual home is subject to the same cyclical fluctuations as an apartment, loans for thirty-year periods on FHA-insured single homes are accepted practice. ${ }^{194}$ Cooperatives seeking similar loans have been unsuccessful. ${ }^{195}$ True, a larger amount is risked on a cooperative apartment; but, as compared with the combined total of single-home mortgages granted by a given lender, the co-op involves no greater risk.

Another reason advanced to justify the lenders' refusal to grant mortgages on section 213 projects is the alleged inadequacy of the statutorily fixed interest rate. ${ }^{190}$ Thus, in a tight money market, the argument runs, the $4 \mathrm{I} / 2$ per cent yield on a cooperative apartment cannot compete with the five to $5 \mathrm{r} / 2$ per cent rate on conventional loans. ${ }^{197}$ And although Congress tends to raise the maximum rates in response to serious market changes, it is urged, the

profits. See N.Y. Times, April 25, 1958, p. 26, col. 6 (letter to editor by A.E. Kazan, Exceutive Vice President, United Housing Foundation criticizing, among other things, use of long-term mortgages).

193. See note $18 S$ supra; authorities cited in note 192 supra. Although delay in collection may be shorter under $\S 213$ insurance than under state foreclosure procedures, there still is a fairly lengthy waiting period. Moreover, even if the mortgagee utilizes the method of collection involving the least delay-assigning his rights to the FHA which in turn handles the foreclosure proceedings-he must bear a $1 \%$ foreclosure cost. 52 Stat. 19 (1939), 12 U.S.C. $\$ 1713(\mathrm{~g})$ (1952).

194. In 1955, the average amortization period for FHA-guaranteed loans on single homes was approximately 28 years. 22 FHA ANN. REP. $98-101$ (1955); see also $21 i d$. at 102 (1954); 1956 VA ANN. Rep. 107 (length of permitted VA loans 30 years). And in 20 states over $20 \%$ of the single-home mortgages contained a 30-year term. 22 FHA ANN. REP. 102 (1955). Moreover, the general trend is for longer mortgage amortization periods. Grebler, Blank, \& Winnick, Capital Formation in Residential Real Estate $232-33$ (1956).

195. See note 185 supra. A 30-year term would probably be acceptable to most co-ops. See N.Y. Times, supra note 192. The Bowery Savings Bank, a leading financier of $\S 213$ co-ops, see 1950 House Hearings 303 , generally limits its loans to 30 years. See N.Y. Times, April 7, 1958, \& \& (Real Estate), p. 1, col. 8.

196. Interviews, supra note 188; 1957 Senate Hearings 355-72, 382, 522.

197. Veterans' Homebuilding-It Lags Because of Tight Money, Time, March 20, 1957 , p. 98. A shift from investment in banks to corporate securities makes it likely that interest rates will continue to rise over the long run. See Nat'l Savings and Loan League, Trends in Home Mortgage Lending, in 1957 Senate Hearings 470.

The President and lenders have advocated elimination of the FHA-pegged rate so that FHA loans can follow the market rate. S. Doc. No. 86, 85th Cong., 2d Sess. (1958) ; Colean, U.S. Housing Grons Urges: (1) Greater Reliance on a Competitive Marketing Economy, (2) Greater Commumity Responsibility, Banking, Feb. 1954, p. 42.

For an opposing view, see 1957 Honse Hearings on Veterans' Affairs 322. 
revisions are only partial and usually come long after the competitive rate has risen. ${ }^{108}$

This argument is also refuted by actual lending practice. Mortgage money for cooperatives has not been forthcoming even during easy-money periods when the maximum rate under section 213 was competitive. ${ }^{199}$ More important, unless the money market is especially tight, ${ }^{200}$ lenders can raise the yield on an FHA-insured mortgage to the competitive level by utilizing discounts. For example, a loan of only $\$ 9,500$ on a twenty-five-year term, $41 / 2$ per cent mortgage with a principal obligation of $\$ 10,000$ increases the yield to five per cent. $^{201}$ Despite statutory and administrative restrictions, discounts of this sort have consistently been used to circumvent unattractive interest rates under other FHA programs. ${ }^{202}$

In conclusion, then, the opposition to lending on cooperative-apartment mortgages must be attributed to reasons which potential creditors have not articulated. One such reason is that institutional lenders are generally unwilling to depart from established patterns of financing:203 despite the FHA's

198. See 1957 House Hearings 413 (rate increase from $4 \mathrm{~T} / 4$ to $4 \mathrm{~T} / 2 \%$ lauded, but decried as too modest) ; id. at 559 ; 1957 Senate Hearings $394-95$ (pointing out difficulty of maintaining pegged rate at level of fluctuating market rate) ; authorities cited notes 196, 197 supra. The maximum interest rate under $\$ 213$ has risen from $4 \%$ in 1950 , to $4 \pi / 4 \%$ in 1953 , and $4 \frac{1}{2} \%$ in 1956. 1958 Senate Hearings 84 .

199. In early 1954, before the change of evaluation from replacement cost to value, the money market was comparatively soft. H.R. REP. No. 2963, 84th Cong., 2d Sess. 42 (1956). Yet financing was still a major roadblock to the development of $\$ 213$ co-ops. Id. at 58 . Other periods in which the FHA interest rate was competitive include 1950-53, and early 1955. Ewalt, Government in Housing and Home Financing, The "G.I." Loan, Savings and Loan News, Sept. 1957, pp. 52, 55; 18 FHA Ans. Rep. 1 (1951); 19 id. at 3 (1952). Section 213 mortgages were almost unobtainable during these periods. See REPoRT of THIL President's Advisory Conanittee on Governament Housing Poltcies and Prograns 41 (Dec. 1953) ; North, supra note 185 , at 332.

200. For an explanation of discounts see H.R. REP. No. 2963, supra note 199, at 40-41. In an extremely tight money market, discounts may become so large that lenders will avoid using them. Hearings on S. 2995, S. 3258, S. 3336, and S. 3373 Before the Sviatc Conmittee on Banking and Currency, 85th Cong., 2d Sess. 96 (1958). See 1957 Houss Hearings on Veterans' Affairs, 242-45; Hearings on Bills Seeking to Permit Use of NSLI Trust Fund to Create Secondary Market, Before the House Committee on Veterans" Affairs, 84th Cong., 2d Sess. 361-62 (1956) ; 1957 House Hearings 232 (giving reasons for lender avoidance of unusually large discounts). Discounts on FHA (unlike those on VA) mortgages have rarely become excessive. See generally 1957 Senate Hearings 357-61.

201. S. ReP. No. 1448, 84th Cong., 2d Sess. 58 (1956). The discount is usually passed on to the individual cooperator in the form of a higher down-payment. See H.R. REP. No. 2963, supra note 199, at 41; 1957 House Hearings on Veterans' Affairs, 121.

202. A survey of the legal restrictions on discounts is presented in id. at 119-21 (statement of Director, Housing and Home Finance Agency). See also N.Y. Times, Aug. 6, 1957 , p. 1, col. 8. Strict discount controls were recently repealed after less than a one-year try-out period of ineffectiveness. Act of April 1, 1958, $\$$ b, 72 Stat. 73.

203. 1949 House Hearings 35. See also Gillies \& Curtis, The Structure of Local Mortgage Markets and Government Housing Finance Programs, 10 J. FIN. 363 (1955). But see Yesterday and Now, Banking, March 1954, p. 43. 
efforts to interest these lenders in section $213,{ }^{204}$ the cooperative apartment represents a form of land tenure with which they are totally unfamiliar, save for a few exceptions in New York. ${ }^{205}$ Another explanation may be that cooperatives of any kind are frequently viewed with suspicion as a form of "socialism." 200 Seemingly, therefore, even though section 213 has eliminated almost all of the economic risks involved, lenders continue to abstain from cooperative-apartment financing for noneconomic reasons.

\section{Two New Answers: More FNMA, Union Pension Funds}

Efforts to increase the availability of funds for cooperative-apartment financing need not rely on private, institutional lenders. A federal corporation could be organized to lend directly, as originally proposed in the committee draft of the 1950 housing bill. ${ }^{207}$ Of course, Congress' persistent refusal to adopt such a plan indicates its political unfeasibility. ${ }^{208}$

Cast in a slightly different form, however, namely the FNMA advancecommitment program, the direct-lending approach is more likely to succeed. Although the operations of the FNMA are usually described as creating a secondary market for mortgages, ${ }^{209}$ its function in issuing advance commitments is actually that of a primary lender. ${ }^{210}$ The private institution originally making the loan simply grants the mortgage, sells it to the FNMA, and derives another fee for its service as an intermediary by charging the cooperative a higher discount than is in turn exacted by the FNMA. ${ }^{211}$ In effect,

204. 22 FHA ANN. Rep. 6 (1955) (special meetings); 1949 House Hearings 43. See also House \& Home, July 1958, p. 63 (appointment of special commissioner).

The FHA staff has been inadequate to carry out this function fully. H.R. REP. No. 2963, supra note 199, at 32, 33, 55; 1957 House Hearings 672-73.

205. See 1957 House Hearings 672; 1949 House Hearings 43. See also 1958 Senate Hcarings 673; interviews with savings and loan officials in Cleveland, Ohio, Aug. 26-Sept. $5,1958$.

206. Peer, Cooperatives and Proprietary Corporations-Distinctions Without a Difference, 34 CoRNeLL L.Q. 416, 417 (1949); Hearings on S.J. Res. 38 and S. 1056 Before a Subcommittee of the Senate Committee on Banking and Currency, 85th Cong., 1st Sess. 32 (1957) (Senator Clark noting tendency to align cooperative apartments with "creeping socialism"). As to lending-institution opposition to "socialistic" tendencies in federal aid to housing, see Edgerton, supra note 187, at 26, 28.

207. See text at note 63 supra.

208. See note 69 supra.

209. Grebler, The Role of Federal Credit Aids in Residential Construction $42-49$ (1953) ; H.R. REP. No. 2963, 84th Cong., 2d Sess. $81-82$ (1956); Hearings on S.J. Res. 38 and S. 1056, supra note 206, at 37.

210. On the distinction between primary and secondary sources of mortgage funds, see Grebler, Blank \& Winnick, Capital Formation in Resmential Real Estate 256 (1956).

211. 1956 House Hearings 567; Proceedings, 1958 Cooperative Housing Conference 63; 1957 House Hearings 246. See generally FNMA, BACKGRound AND History of the Federal National Mortgage Association 28-30 (April 30, 1955).

The mortgagee is not required (as is usually the case) to continue servicing the $\S 213$ mortgage after selling it to the FNMA; the FNMA services multifamily dwelling mort- 
the FNMA is the lender and the private financial institution its agent. The rapid exhaustion of the FNMA's authorized section 213 mortgage portfolio ${ }^{212}$ indicates that, despite their lack of enthusiasm for cooperatives in general and the FNMA's special-assistance functions in particular, ${ }^{213}$ institutional lenders are anxious to serve as a funnel between the borrower and the FNMAthat is, to take advantage of the advance-commitment program by earning charges without making investments in a suspect form of housing. Moreover, the lender's profits may be increased if he avails himself of the opportunity to grant an FHA-insured temporary loan for financing a co-op's construction. ${ }^{214}$

If it is to solve extant cooperative-apartment financing difficulties, the FNMA's advance-commitment program must be expanded and restructured. Authorized commitments for nonconsumer-sponsored projects (by far the predominant type under section 213) are almost completely exhausted, and the 1958 Congress indicated that additional authorizations are not to be expected in the near future. ${ }^{215}$ Even if the presently inadequate portfolio limit were raised, certain basic statutory provisions would have to be amended before the advance-commitment program would yield optimum results. In order to accord every state an opportunity to utilize special-assistance funds, Congress has consistently imposed a ten per cent limit on the FNMA investment in any one state. ${ }^{216}$ Although this objective may justify some per-state limita-

gages itself. See 24 C.F.R. $\$ 400.81$ (Supp. 1958) ; FNMA, Secondary Market OreraTIONS 8 (Aug. 6, 1957).

212. See authorities cited in notes 115, 129, 130 supra. See also S. REP. No. 94, 85th Cong., 1st Sess. 5 (1957).

Although $\$ 213$ has been used primarily for the construction of cooperative arartments, most FNMA funds have financed cooperatively-built single homes. 1958 Senate Hearings 582 (chart). This allocation was probably due to the fact that no more than $10 \%$ of the funds could be used in one state, and cooperative apartments are a familiar form of dwelling only in New York. See S. Rep. No. 94, supra at 5 (New York one of two states using its complete $10 \%$ allocation of funds, and used it exclusively for apartments).

213. See, e.g., Hearings on S. 2995, S. 3258, S. 3336, and S. 3373 Before the Sente Committee on Banking and Currency, 85th Cong., 2d Sess. 95 (1958) (mutual savings banks). See also McKinley, Residential Mortgage Lending, 7 J. FIN. 1, 28 (1952) ; 1956 House Hearings 566-70 (mortgage bankers) ; 1956 Senate Hearings 637-43 (life insurance companies); id. at 484-85 (American Bankers Association).

214. The combined charge for acting as an intermediary between the cooperative and the FNMA and for financing the construction may be as high as $2 \frac{1}{2} \%$ of the mortgage amount. 1957 House Hearings 246.

215. See text at notes 131-32 supra.

216. 65 Stat. 699 (1951), 69 Stat. 636 (1955), 70 Stat. 1091 (1956), 12 U.S.C. $\$ 1720$ (e) (Supp. V, 1958). See 1957 Houlse Hearings 679 (statement of Wallace J. Campbell, Director, Cooperative League of the U.S.A.) (10\% limit designed to assure "that no one State or small group of states would monopolize the available funds"). Action to raise the limit to $30 \%$ failed in committee. Compare 1955 House Hearings 254 and 1955 Senate Hearings 214, with H.R. REP. No. 913, 84th Cong., 1st Sess. 11 (1955).

Proposals for additional FNMA special assistance for $\$ 213$ mortgages have contained the $10 \%$ limit. 1957 House Hearings 246, 647. 
tion, ${ }^{217}$ the ten per cent restriction does not comport with the strikingly uneven geographic distribution of the middle-income housing shortage. ${ }^{218}$ Any restrictions on FNMA investments should be geared to that distribution, and should also reflect the fact that, because cooperative apartments continue as cooperatives after construction, they can provide housing at lower cost than cooperatively built single homes. 219

Another unduly restrictive aspect of the present FNMA advance-commitment program is the $\$ 15,000$ per-unit ceiling on the amount of a purchasable mortgage, ${ }^{220}$ for it excludes loans to co-ops located in high-cost areas, and to those with seven-room units for large families. ${ }^{221}$ (The 1958 bill proposed a higher ceiling, but one which was still stated in terms of a flat amount per unit.) ${ }^{222}$ The difficulties raised by this arbitrary limitation could be avoided if the FNMA were authorized to purchase any FHA-insured co-op mortgage. ${ }^{223}$

Amended to incorporate the proposed changes, the FNMA's advance-commitment operations could reduce the present financing difficulties caused by reliance on private lenders. In view of Congress' attitude toward direct lending, however, the special-assistance program, which is in reality only another form of direct federal support, is unlikely to be so expanded as to obviate the

217. If no per-state limitation were applicable, the FNMA fund might be depleted by sponsor-builders, such as those in New York City, before builders in other states with almost equally acute middle-income housing shortages could familiarize themselves with the co-op form and begin to take advantage of the \$213-FNMA program.

218. Compare 1956 Sente Hearings 212 (intense housing shortage in New York), with Johnstone, The Federal Urban Renewal Progran, 25 U. CHr. L. REv. 301,331 (1958) (Iowa, Oklahoma, Utah and Wyoming have not requested federal aid for public housing, presumably because of the absence of a serious housing shortage). Equating the amount of funds available for New York cooperatives with Wyoming cooperatives, while politically sound in so far as the Senate is concerned, is inconsistent with the overall objective of reducing the middle-income housing shortage.

Originally, the $10 \%$ limit was applied in a most onerous fashion. A state was considered to have depleted its authorization once FNMA had purchased mortgages in that state in an amount equal to $10 \%$ of the total FNMA authorization. The FNMA ignored the fact that the special-assistance fund is of a revolving nature and the primary consideration is value of the mortgages from one state presently in the portfolio; mortgages purchased and later resold are irrelevant to computation of the percentage of the total fund used by mortgagees in any one state. Congress eventually notified the FNMA of its error. F.R. REP. No. 2963, supra note 209, at 59-60; H.R. Rep. No. 2363, 84th Cong., 2d Sess. 24 (1956).

219. See, e.g., text at note 335 infra.

220. 64 Stat. 57 (1950), as amended, 12 U.S.C. $\S 1717$ (b) (Supp. V, 1958).

221. See 64 Stat. 55 (1950), as amended, 12 U.S.C. $\$ 1715$ (b) (Supp. V, 1958), stating the per-room limits on the amount of an FHA-insured $\$ 213$ mortgage.

The median room count of $\S 213$ co-ops was 5.2 rooms in $1955.1955 \mathrm{H} \&$ HFA ANN. REP. 207. But many co-ops are elevator structures or are located in high-cost areas. See, c.g., Co-op Activity \& Housing News, May 1958, p. 5, cols. 1-3.

222. See $\$ 301$ of S. 4035, in 104 Cong. REc. 16791 (daily ed. Aug. 18, 1958).

223. But see Akin, The Mortgage Market and FNMA, 23 ApPraISAL J. 421, 425 (1955). 
demand for private investment altogether. Another solution, more feasible in that it relies on private investment, is increased borrowing from employee pension funds. These funds, presently estimated at $\$ 25$ billion, represent a constantly expanding potential source of mortgage money. ${ }^{224}$ To date only a small percentage of this amount has been invested in mortgages, although a large portion of that so invested has been in middle-income cooperative apartments. ${ }^{225}$ Thus, seven major labor unions have used pension-fund money to finance the construction of co-ops ${ }^{226}$ (not all of them under section 213, however). ${ }^{227}$

The failure of pension funds to invest more heavily in cooperatives has been variously explained. One reason given is that those who administer the funds-frequently employers or trustees appointed by employers-have the same aversion to investing in cooperatives as do private lenders. ${ }^{228}$ This explanation is unpersuasive, for it overlooks the impact of labor unions on the determination of pension-fund investment policy. Although unions may not administer the funds, they frequently dictate the area of investment through

224. 1956 REP. of N.Y. Housing CoNM'R 470; Meyer, Broadening the Market for FHA-VA Mortgages, Commercial \& Financial Chronicle, May 3, 1956, pp. 1, 30. Utilization of pension funds as a secondary market for mortgages has long been advocated. See Colean, Suggestions for Opening the Pension Funds to Mortgages, Mortgage Banker, April 1955, p. 16; House \& Home, April 1956, p. 45.

225. A New York report revealed $0.244 \%$ of pension-fund capital was invested in mortgages. 1956 REP. OF N.Y. Housimg Conm'R 473. This percentage is indicative of pension-fund investment throughout the country. Meyer, supra note 224, at 30 (4\% miscellaneous group of investments including mortgages as one component). On the success of co-ops in attracting a substantial portion of that investment, see 1956 REP. OF N.Y. Housing Comm'r 474-75.

226. Flexner, Cooperative Housing in United States, Construction Rev., June 1958, pp. $4,8$.

The Amalgated Clothing Workers began to support cooperatives in 1927. Wood, RECENT Trends in Amrerican Housing 180-81 (1931.).

227. Some unions have preferred to avoid the $0.5 \% \mathrm{FHA}$ insurance charge and therefore forego the security of government mortgage insurance. ProceEdnvgs, 1958 Coorerative Housing Conference 38. For examples of co-ops financed by employee-pension funds without government aid, see Camphell, Progress in Cooperative Housing, 1957 Housing YEARBOoK 32-33 (International Ladies Garment Workers and International Brotherhoud of Electrical Workers projects totalling 4,828 units). On pension-fund-sponsored co-ops employing $\$ 213$ insurance, see ProceEdings, op. cit. supra, at insert following p. 40 (Textile Workers). For instances of other types of pension-fund investment in mortgages, see 1957 Senate Hearings 844 ; Business Week, Dec. 15, 1956, p. 531; id., Dec. 29, 1956, p. 70.

228. See Procefoings, 1958 Cooperative Housing Conference 61. See also 1956 ReP. of N.Y. Housing Comm'R 478; Meyer, supra note 224, at 1 (many trustees advising pension funds are more familiar with bonds and stocks than mortgages).

Eighty-six per cent of all pension funds are administered unilaterally by the employer or his agent. Note, 67 Y ALE L.J. $736 \mathrm{n.7}$ (1957). Section 302 of the Taft-Hartley Act requires equal representation of union and management in the administration of pension funds organized after 1946 and receiving employer contributions. 61 Stat. 157 (1947), 29 U.S.C. $\$ 186$ (1952). 
collective bargaining. ${ }^{29}$ Consequently, the unions' traditional strong support of cooperative housing could often overcome any employer disinclination to promote co-ops. ${ }^{230}$ Furthermore, that small percentage of total pension funds controlled exclusively by unions represents a substantial amount of potential investment capital. ${ }^{231}$ Thus, the failure of pension funds to invest more heavily in co-ops cannot be attributed solely to the unfavorable attitudes of the funds' trustees.

Another reason advanced for the funds' limited investments in cooperatives is that pension plans call for long-term securities, not mortgages which are constantly reduced by amortization payments. ${ }^{232}$ This objection could be partially overcome by extending the co-op mortgage for the full forty-year period allowed by statute. Moreover, it is questionable whether the relative liquidity of mortgages with even shorter terms is so inconsistent with the preference for long-term securities as to constitute an important restraint on pensionfund investments in co-ops. ${ }^{233}$

229. See, c.g., N.Y. Times, June 22, 1958, p. 65, col. 6 (Ford-Reuther fight over investment of pension funds); P-H Pension \& Profit Straring Serv. If 7071 (1957); Business Week, Dec. 31, 1955, p. 66 (President Meany of CIO-AFL calls on unions to exert pressure for investment of pension funds in middle-income housing). The argument has been made, however, that "unions do not want to get too involved in the problems of pension fund investment, as it is felt that this may detract from the time and energy that can be given to the union's primary concern-collective bargaining and the general economic welfare of all its members. But, if this criticism is valid, it could be leveled equally at any kind of investment activity by the union, even though it might be an integral part of providing for the economic welfare of its members. The pension funds have to be invested; all that is under discussion is the form the investment should take." 1956 REP. of N.Y. Housing Conru'R 478.

230. For union support of cooperative housing, see, e.g., Woon, op. cit. supra note 226 , at 175-95; Business Week, Feb. 23, 1957, p. 75; authority cited concerning union support, note 55 supra; 1956 Sente Hearings 395-98 (statement of AFL-CIO on FNMA).

Unions have generally supported cooperatives of all types. Rees, Labor and Co-operatives; What's Wrong?, 6 ANTIOCH Rev. 327, 332-33 (1946); Pfretzschner, The Unions and Co-ops: A Look Into The Future, 61 DICK. L. Rev. 76-77 (1956). Unions have feared, however, that consumer cooperatives might pay employees below-union wages. MinIIs \& Montcomery, ORGanIzed Labor 341 (1945). In the case of $\$ 213$ co-ops, however, this fear should be overcome by the FHA requirement that contractors must pay the prevailing wage. 24 C.F.R. $\$ 241.28$ (Supp. 1958).

231. 1956 REP. of N.Y. Housing Consar's 473 (over $\$ 443$ million controlled by three union-administered pension funds).

232. Id. at 477. See also Belter, Trade Union Investment Policies, 6 IND. \& LAB. REL. Rev. 337, 350 (1953). But see Proceedings, 1958 Cooperattve Housing Conference 25 : "The big obstacle today is that these funds must be kept in such form as to be available to meet any possible emergency. Administrators, for that reason, hesitate to invest in 40 year mortgages."

233. Mortgage payments on $\$ 213$ projects are usually quite substantial. A fund investing in such mortgages therefore does not have the problem-usually associated with investment in mortgages on single dwellings - of receiving small individual payments which must be reinvested. 
A more serious deterrent to this type of investment is the fact that pension funds lack the facilities for servicing mortgages. 234 This inability could be remedied by hiring institutional lenders familiar with mortgage problems to perform the servicing function. Since these same lenders have readily stepped into an identical role under a large segment of the FNMA's advance-commitment and secondary-market programs, ${ }^{235}$ coordination between the servicing lender and the pension fund could, in all likelihood, be achieved. In fact, bankers have already expressed a willingness to service pension-fund mortgages for a fee of 0.5 per cent of the outstanding balance. ${ }^{236}$ Pension-fund trustees have opposed such a division of the servicing and investing functions on the ground that this delegation of their duties would leave them open to charges of breach of fiduciary responsibility. ${ }^{237}$ A statement of authorization in the trust agreements would meet this objection. ${ }^{238}$

In addition, pension funds should be permitted to purchase partial shares in co-op mortgages. Some funds have insufficient capital to finance large-scale projects, ${ }^{239}$ and others could do so only by foregoing investment diversification. ${ }^{240}$ True, many jurisdictions do not include partial interests in mortgages on their lists of approved trust investments. ${ }^{241}$ But since these lists limit a trustee only in matters not provided for in the trust agreement, their restrictive effect can be circumvented by a specific trust provision authorizing the purchase of shares in a co-op mortgage. ${ }^{242}$

234. 1957 House Hearings 345 ; 1956 REP. of N.Y. Housrng CoMMr'R 476.

235. 24 C.F.R. $\$ 400.81$ (Supp. 1958). See FNIMA, BACKGRound AND History of THE Federal National Mortgage Association 32-35 (April 30, 1955); FNMA, Servicers Gurde 1-3 (1955). Payment for this service is, simply stated, $0.5 \%$ of the unpaid mortgage balance. Background and History, supra at 33. See Servicers Gutde, supra at 44-52 (explaining in detail the method of computing the servicing charge).

236. See P-H Pension \& Profit Sharing Serv. If 7067-7069 (1955) ; N.Y. Times, Aug. 18, 1957, § 8 (Real Estate), p. 1, col. 8 . Bankers perform the same function for insurance companies. 1956 House Hearings 568.

237. 1956 Rep. of N.Y. Housing Comm'R 476.

238. See Zimmerman v. Fraley, 70 Md. 561, 17 At1. 560 (1889); Restatement, TRUSTS § 164 (1935).

239. 1956 Rep. of N.Y. Housing Coms'r 476.

240. Meyer, supra note 224, at 31.

241. See, e.g., statutes of District of Columbia and Michigan, collected in 4 P-H WILLS, EsT., \& TRUsTs \ 15301 (1950). Legal lists of other states include notes secured by mortgages, but fail to mention partial interests and therefore might exclude such interests by negative inference. See, e.g., statutes of Louisiana, Nebraska and New Hampshire collected in ibid. But see Comment, 45 Yale L.J. 857, 876 (1936). For another type of restriction, see Alabama statute, quoted in P-H WrLls, Est., \& Trusts ff 15301 (1950) ("no interest or participation in any note, bond, or other evidence of indebtedness shall be purchased ... unless the entire principle indebtedness secured by the mortgage shall at the time be controlled by the fiduciary").

242. City Bank Farmers Trust Co. v. Lewis, 122 Conn. 384, 386-87, 189 Atl. 179, 180 (1930) ; In re Gigg's Estate, 116 N.Y.S.2d 90 (Surr. Ct. 1952); In re Gillingham's Estate, 353 Pa. 493, 46 A.2d 269 (1946) ; P-H Pension and Profit Sharing Serv. 17052 (1955). Cf. Macy v. Mercantile Trust, 68 N.J. Eq. 235, 59 Atl. 586 (1904). The authorization 
New York, where many pension fund trustees and most cooperative apartments are found, presents a special problem: trust investment in a portion of a mortgage is statutorily prohibited. ${ }^{243}$ The history of abusive practices and excessive defaults in cases involving joint mortgages may justify this prohibition as it applies to conventional mortgages. ${ }^{244}$ Government-insured mortgages, on the other hand, entail little risk, and FHA supervision should prevent abusive practices in the financing of cooperatives. In fact, the comparatively risk-free nature of FHA-insured mortgages has already been recognized by the New York legislature, which excepts them from the rule that, absent trust-indenture language to the contrary, trusts can only invest in mortgages having a loan-to-value ratio of no more than fifty per cent. ${ }^{245}$ An amendment of the New York statute to permit pension-fund ownership of partial interests in co-op mortgages would, therefore, be consistent with the legislature's evaluation of the safety of FHA-insured mortgages-and with the legislature's acknowledged goal of promoting middle-income housing, as well.246

Once the obstacles of inadequate servicing facilities and prohibitions against accepting partial mortgages were removed, pension funds could make advantageous investments in cooperative apartments, for section 213 mortgages would increase fund income in a financially sound manner. Approximately one-fifth of pension-fund capital is presently invested in government bonds yielding a maximum of three per cent; almost half of the funds are invested in corporate bonds having an average rate of return of no more than $3 \mathrm{r} / 2$ per cent. $^{247}$ In contrast, section 213 cooperative-apartment mortgages, with a servicing fee deducted, would yield approximately four per cent. ${ }^{248}$ Insured as they are by the FHA, moreover, these mortgages are virtually as risk-free

must be explicit. Cf. In re Staudinger's Will, 112 N.Y.S.2d 100 (Surr. Ct. 1952); Pabst v. Goodrich, 133 Wis. $43,76,113$ N.W. 398, 408 (1903). But cf. Thayer v. Dewey, 185 Mass. 68, 69 N.E. 1074 (1904). Of course, even if authorized to invest in mortgage participations, the trustee still has the duty to ascertain that the security value of the property interest underlying the mortgage is adequate. See Gilbert v. Kolb, $85 \mathrm{Md} .627,37 \mathrm{Atl} .423$ (1897); In re Randolph, 134 N.Y. Supp. 1117 (Surr. Ct. 1911), aff'd, 150 App. Div. 902, 135 N.Y. Supp. 1138 (1912) ; Roach's Estate, 50 Ore. 179, 193-96, 92 Pac. 118, 124-25 (1907).

243. N.Y. Pers. Prop. LAw $\$ 21(5)$; In re Coulter's Estate, 121 N.Y.S.2d 531, 535 (Surr. Ct. 1953).

244. See Comment, 45 Y ALE L.J. 857, 878 n.86 (1936).

245. N.Y. Pers. Prop. Law $\$ 21$.

246. On the New York legislature's interest in middle-income housing, see N.Y. Times, Aug. 25, 1957, \& 8 (Real Estate), p. 1, col. \&; Harriman, Middle Income Housing Pases Basic Problen, id., Oct. 26, 1958, $\S 10$ (Advertisement), p. 5, col. 5; McMurray, State and Municipally-Aided Kings Bay Housing, id., p. 12, col. 4.

Other arguments in opposition to pension-fund investment in mortgages are raised and answered in 1956 REP. OF N.Y. Housing COMM'R 478.

247. See Meyer, supra note 224, at 30; 1956 Rep. of N.Y. Housrng Canm'R 473-77. See also P-H Pension \& Promt Sharrng Serv. ff 7053 (1958) (sampling of 7 pension trusts shows an even higher percentage of investment in government bonds).

248. See text at notes 72, 236 supra. See also 1956 Rep. of N.Y. Housing Comm'R 474. 
as government obligations, and are safer than corporate bonds. ${ }^{249}$ FHA insurance does, of course, have one drawback, in that benefits are paid in debentures. The debentures are ordinarily redeemed within one year, however, and in any event their $31 / 8$ per cent interest rate is greater than that paid on government bonds. Were pension funds to invest in cooperatives, ample financing could be achieved without the funds' unbalancing their portfolios: an investment of one-twentieth of the total of all pension funds would be $\$ 1$ billion, with an additional increment of $\$ 100$ million per year. ${ }^{250}$

More constructively, an investment of this magnitude in co-ops would enable labor unions to satisfy one of the workingman's greatest needs-adequate housing. ${ }^{251}$ Pension-fund financed cooperative apartments, while ordinarily open to the public at large, have often granted priority to union members. ${ }^{262}$ In addition, by reducing the mortgage interest rate to $3 \mathrm{I} / 2$ per cent, a pension fund can retain a yield equal to that obtained on government and many corporate bonds, and, at the same time, lower the price of housing to its members. ${ }^{253}$ Whether this practice will become more common will depend to a large degree upon the attitudes of those union members who do not live in cooperatives, that is, on whether they oppose special benefits for those who do. Conversely, membership occupancy may create ill will if the pension-fund mortgagee forecloses. To offset this possibility, control over the cooperativeapartment mortgage might be exercised so as to obtain a form of built-in unemployment insurance. When mass unemployment occurs, the union might compel the trustee to impose a moratorium on mortgage assessments. The wholesale ejection of union-member cooperators would thus be avoided, and, as a result, the pension fund would be used to mitigate the effects of serious declines in employment. ${ }^{254}$

249. One commentator argues that mortgages should not be compared only to bonds, but with higher-yield fund investments as well. Meyer, supra note 224, at 30 . To do so, however, would be to disregard the requirement that every pension fund contain a significant percentage of absolutely-secured investments-that is, of government-backed bonds or mortgages.

250. 1956 Rep. of N.Y. Housing CoMm'R 473.

251. See 1950 House Hearings $344-66(65-70 \%$ of $\mathrm{ClO}$ members are in the middleincome group); Business Week, Feb. 23, 1957, pp. 75-80.

252. See, e.g., N.Y. Times, Feb. 25, 1958, p. 26, col. 3 (editorial); id., May 16, 1957, p. 1 , col. 7, p. 21 , col. 2 .

253. The International Brotherhood of Electrical Workers held the interest rate on their Queens project down to $4 \%$, although union members constituted only $30 \%$ of the cooperators. The pension fund's previous investment-government bonds--had been paying only $2 \mathrm{~T} / 2 \%$. Proceedings, 1958 Cooperative Housing Conference $38-40$.

254. As an answer to the problem of inducing pension-fund investment in mortgages, many commentators have suggested the organization of a private, state-regulated corporation which would sell debentures to pension funds and use the proceeds to buy mortgages. See, e.g., 1956 ReP. of N.Y. Housing Comm'r 479; 1957 Senate Hearings 472; ProceEDings, 1958 Cooperative Housing Conference 25. This solution extends beyond cooperative housing, and thus loses the cost advantages acquired through that form of land tenure. See note 326 infra; text at notes 327-35 infra. Also, it fails to ensure availability of hous- 


\section{Sponsors}

A sponsoring entity is essential to the success of a middle-income cooperative apartment, for its organization cannot depend upon the spontaneous assemblage of a group of people interested in becoming cooperators. ${ }^{255}$ Even if such a group did come together, it would probably be ill-equipped to handle the manifold problems involved in purchasing land, arranging for finance and construction, and qualifying the co-op for FHA mortgage insurance. ${ }^{256}$

Section 213 cooperatives have been sponsored primarily by either of two groups: specialized nonprofit organizations which, representing a body of prospective purchasers, initiate the so-called consumer co-ops; and members of the home-construction industry (contractors and real estate agents, for example), who promote the builder co-ops. ${ }^{257}$ Although favored by Congress, ${ }^{258}$ consumer co-ops represent but a small fraction of the total apartment units built under section $213 .{ }^{259}$ The future growth of consumer co-ops will depend upon either the increased development of nonprofit sponsoring organizations, ${ }^{200}$ or an improvement in the services rendered consumer groups through

ing for union members, since it confers insufficient union control over the mortgaged property.

255. See Abrams, U.S. Housing; A New Program, New Leader, Jan. 13, 1958, § 2 , p. 9 (emphasizing that the original cooperators often have "conflicting ideas, hopes and wives").

256. See ibid.; Flexner, Cooperative Housing in the United States, Construction Rev., June 1958, pp. 4, 5; 1957 House Hearings 672.

257. Commentators sometimes talk of three types of cooperatives-consumer-sponsored, builder-sponsored, and organization-sponsored. Consumer-initiated co-ops are almost always sponsored by an organization, however, and statistics on sponsorship usually classify both under the former heading. See Proceedings, 1958 Cooperative Housing CONFEREnCE $23-24,31 ; 1956$ Senate Hearings 425-26. On the types of professional persons who participate in "builder" sponsorship, see FHA, Summary Statement [:] Section 213 Cooperative Housing (Form No. 3239, 1956).

258. H.R. Rep. No. 2963, 84th Cong., 2d Sess. 57 (1956).

259. Proceedings, 1958 Cooperative Housing Conference 29, 31 (consumer-sponsored co-ops represent only a $\$ 13$ million investment). See also Campbell, Progress in Cooperative Housing, 1957 Housing YeARBook 32. In recent years, the number of consumer cooperatives has risen sharply, although they are still a distinct minority. 1958 Housc Hearings 332 ; Flexner, supra note 256, at 5 . Consumer co-ops have been sponsored by trade unions, teachers' organizations, veterans' posts, credit unions and religious bodies. 1958 Senate Hearings 587. Veteran and labor groups began sponsoring co-ops long before the enactment of $\S 213$. See, e.g., N.Y. Times, May 28, 1946, p. 36, col. 8 (veterans) ; New Building for Amalgamated Clothing Workers, 34 Montruy LaB. REv. 1090 (1932) (unions).

260. Even large labor unions with wide organizational experience have found it necessary to call upon two nonprofit corporations which were formed to aid consumer groups in planning co-ops. 1957 House Hearings 672; 1954 Senate Hearings 976, 985. For a description of co-ops sponsored by one such group, The Mutual Housing Corporation, see Co-op Activity \& Housing News, May 1958, p. 5, cols. 1-2. On the United Housing Foundation, another specially-organized sponsoring organization, see N.Y. Times, July 12, 1957 , p. 23, col. 5 . 
the FHA technical-assistance program. ${ }^{261}$ Although both are likely, immediate results are not. ${ }^{262}$ Consequently, members of the building industry will continue to be the principal entrepreneurs initiating cooperative apartments-for the near future, at least. ${ }^{263}$

Builders have a strong economic incentive to act as sponsors, since they find a ready market in cooperative corporations having adequate equity capital.204 Even when the purchaser of an apartment building can acquire a mortgage loan representing a high percentage of cost, he will need considerable equity capital to make up the difference between loan and purchase price. Currently, however, rental apartments are not, by and large, particularly attractive investments. ${ }^{265}$ The co-op therefore presents the builder with an exceptional

261. See H.R. Rep. No. 2963, 84th Cong., 2d Sess. $55-56$ (1956); 1956 Senate Hearings 427.

262. An increase in sponsoring organizations may result from the newly-organized coop advisory committee to the FHiA which consists of representatives of labor, veteran, religious and civic groups. 1957 Senate Hearings 943. Nevertheless, in view of the slow progress made by consumer groups so far, their immediate expansion to a position of predominance is unlikely. But see 1958 House Hearings 332.

The FHA technical-assistance program has been of little aid to consumer groups. Procendings, 1958 Cooperative Housing Conference 31. See also authorities cited note 261 supra. Improvement is expected, however. PRoCEEDINGS, supra at 31 (FHA official promises better service) ; 1957 House Hearings 673 (attitude of FHA branch-office officials toward co-ops is improving). One commentator has advocated the organization of governmentchartered building and loan associations designed specifically to give financial and technical aid to co-ops. Abrams, supra note 255 , at 8 .

263. On the importance of builder-sponsors in the cooperative housing movement, see H.R. Rep. No. 2963, 84th Cong., 2d Sess. 57 (1956) ; N.Y. Times, Jan. 4, 1959, \& \& (Real Estate), p. 1, col. 8 ("Although Section 213 was designed to attract nonprofit housing groups, almost all the 213 cooperatives [in New York City] were built by speculative builders . . . .) ; Clearview Associates, Inc. v. Clearview Gardens First Corp., 8 Misc. $2 \mathrm{~d}$ 470,168 N.Y.S.2d 432, 437-38 (Sup. Ct. 1957) (a basic purpose of $\$ 213$ is to provide profit incentive for builder-sponsorship of co-ops) (dictum).

264. On the problems involved in raising equity capital generally, see Fismer, UREAN Real Estate Markets: Characteristics and Financing 14 (1951). The value of the co-op as an untapped source of equity capital has been noted by advocates of cooperative housing. See, e.g., 1954 Senate Hearings 978, 1957 Senate Hearings 940.

265. Reluctance to invest in apartments stems from various sources. Industrial and other investments offer a higher rate of return. StafF of Subcomsm. of the Senate Coams. on Banking and Currency, 85th Cong., 2o Sess., The Decline in Construction of FHA Insured Rental Housing, in 1957 Senate Hearings 664 ; 1957 Senate Hearings 421. See also Colean, Impotency of FHA Policies on Apartment Finance, 102 ARCHITECTURAL F. 110 (1955). Also, construction has become increasingly a risky venture because of continuing price increases and labor difficulties. Hader \& Levinson, Labor RELATIONS and Productivity in the Building Trades 175-80, 223-40 (1956). Urban blight, increased property taxes, rent control, and the headaches involved in operating an apartment also discourage investment in apartments. See Hennessey, Co-operative Apartments and Towm Houses, 1956 ILL. L.F. 22, 23; Can the Cities Come Back?, U.S. News \& World Report, July 19, 1957, pp. 72-85 (effect of slum encroachment). Investment in apartments is also fraught with tax disadvantages. Prepaid rent is taxable when received regardless of 
opportunity, because the cooperators' down-payments provide a ready-made source of equity capital for the vendee cooperative. Hence, the builder need not seek out investors in order to undertake a project, but instead can simply obtain purchase commitments from prospective cooperators-a comparatively easy task during the present housing shortage. ${ }^{266}$ Once these commitments are in hand, section 213 authorizes the FHA to insure a temporary building loan of sufficient size to cover the cost of construction. ${ }^{267}$ As a result, the builder's only cash outlay is that involved in finding subscribing cooperators and paying the application fee for the insurance; and the building contract would ordinarily reimburse him for both. ${ }^{268}$

whether the landlord is on a cash or accrual basis. South Dade Farms, Inc. v. Commissioner, 138 F.2d S18 (5th Cir. 1943) ; Renwich v. United States, 87 F.2d 123 (7th Cir. 1936). Cf. Fifteen Hundred Walnut Street Corp. v. Commissioner, 237 F.2d 933 (3d Cir. 1956). But see Note, 67 Yale L.J. 1425 (1958) (criticizing the claim-of-right doctrine on which these cases were based). The cost of land, relatively more significant in the case of an apartment building than in that of an industrial development, is not depreciable. Deductions might be obtained through use of the sale-and-lease-back device, however. See Century Elec. Co. v. Commissioner, 192 F.2d 155 (Sth Cir. 1951), cert. denied, 342 U.S. 954 (1952); Cary, Current Tax Problems on Sale, or Gift, and Lease Back Transactions, in N.Y.U., 9TH INST. oN FED. TAX 959 (1951). Also, income realized on sale of the property might constitute ordinary gain, as the investor may be held to be in the business of selling apartments. Profit from the sale of stock, on the other hand, will be treated as capital gain, since classification as a "dealer in stocks" is unlikely. Compare Mauldin v. Commissioner, 195 F.2d 714 (10th Cir. 1952), with Van Suetendael, 3 CCH TAx CT. Menro 987 (1944). But see Grier v. United States, 120 F. Supp. 395 (D. Conn. 1954). For other tax disadvantages of apartment ownership see Mortgage Bankers Association of America, Statement of Policy on Legislation Affecting Real Estate Financing, in 1958 Senate Hearings 773. See also Why You Should Look Into Rental Housing, House \& Home, April 1958, p. 103.

Despite the above-mentioned disadvantages, apartment construction has experienced a boom during the past year which might possibly be a manifestation of renewed investor interest. Ibid. Such interest would be limited to luxury-type apartments, however; middleincome apartments are almost impossible to build without FHA aid, and $\$ 207$-which establishes the primary rental-apartment program-sharply limits the landlord's rate of return. See id. at 106. But see Room Count Rules Changed; MPR's To Be Revised, House \& Home, May 1958, p. 75 (noting a relaxation of FHA restrictions on $\$ 207$ projects).

266. See Co-op Activity \& Housing News, May 1958, p. 6, cols. 1-3 (chart showing waiting periods from 4 months to 2 years for co-op applicants) ; N.Y. Times, Oct. 26, 1958, $\S 10$ (Advertisement), p. 5, cols. $2-4$ (over 2,000 applicants for 540 units in a recentlybuilt co-op) ; N.Y. Times, Jan. 4, 1959, § \& (Real Estate), p. 1, col. 8, p. 2, col. 5 ("most [\$ 213] cooperatives have long waiting lists for ... a apartments").

267. See 24 C.F.R. $\$ 241.4$ (b) (Supp. 1958); FHA, Mortgagor's Certificate for Sec. 213 Projects Involving Insurance of Advances (Form No. 3212, 1957). The down-payments of the cooperators are kept in escrow until the FHA grants an initial endorsement on the mortgage. FHA, Model Form of By-Laws, Art. III, $\$ 3$ (Form No. 3244, 1957).

268. See Nostrand Gardens v. Roche, N.Y.L.J., June 20, 1958, p. 9 (N.Y. Sup. Ct. June 19,1958 ) (preliminary expenses $\$ 12,000$ on a $\$ 3,182,137$ contract). The builder may also have to deposit cash or a bond with the mortgagee as assurance that he will complete the project, 24 C.F.R. $\$ 241.27$ (Supp. 1958), and correct any defects in construction, H \& HFA-FHA, Legal Requirearents in Closing of Section 213 Managearent and Sales Type Projects Involving Insurance on Completion 3 (April 1, 1958). 
If the builder-sponsor owns the site on which the co-op will be built, he can, under section 213 , gain the tax and economic advantages of leasing rather than selling outright. ${ }^{269}$ The FHA will usually insure mortgages covering projects constructed on leased land if the lease is for a ninety-nine year term and contains an option in the lessee to renew. ${ }^{270}$ The sponsor can thus lease his land, since the FHA insurance will enable the cooperative lessee to acquire a mortgage which other types of lessees, who do not qualify for FHA insurance, could not. ${ }^{271}$ In addition, the lease facilitates the sale of individual apartment units, the reduced initial cost of the project being transformed into a lower cash down-payment for each cooperator. ${ }^{272}$

\section{Excessive Sponsor Profits and Self-Dealing}

Builder-sponsors have also exploited the opportunities which section 213 presents for profiteering. ${ }^{273}$ In the early years of the 213 program, a sponsor

269. For the advantages of long-term leases, see FISHER, op. cit. supra note 264, at 35-37; Cohen, Long Termi Leases 53-63, 73-108 (1954).

270. The lease must receive administrative and underwriting approval. $\mathrm{H}$ \& HFAFHA, Legal Requiremients in the Closing of Section 213 Managentent and Sales Type Projects Involving Insurance of Advances 13 (March 1, 1957); 24 C.F.R. \$ 241.40 (a) (Supp. 1958). For the terms usually required to gain official approval, see LEGAL REQUIREMrENTS, supra at 14-16; 24 C.F.R. $\$ 241.40$ (a) (Supp. 1958). See also Northridge Co-op Section No. 1, Inc. v. 32nd Ave. Constr. Corp., 207 Misc. 164, 136 N.Y.S.2d 737 (Sup. Ct.), modified, 286 App. Div. 422, 142 N.Y.S.2d 534 (1955), aff'd, 2 N.Y.2d 514, 141 N.E.2d 802, 161 N.Y.S.2d 404 (1957). The per-annum ground rent must not represent more than $4 \mathrm{~T} / 2 \%$ of the FHA valuation of the land. LEGAL REQUIREMENTS, supra at 14. In addition to the option to renew, the co-op may also insist upon an option to purchase after 15 years at an FHA-approved price. Ibid.

271. Anderson, Cooperative Apartments in Florida: A Legal Analysis, 12 U. Minam L. Rev. 13, 34 (1957) (discussing difficulty lessees encounter in obtaining uninsured mortgages); 1957 House Hearings 673. Lessee mortgagees are a familiar concept in some eastern cities. FrSHER, op. cit. supra note 264 , at 38 n.1.

The FHA protects its interest in the security by making the written consent of the Commissioner a prerequisite to the landlord's implementation of his right of entry upon rent default. FHA, Model Form of Ground Lease, 92 (Form No. 114893, Feb. 1954). See also $\mathrm{H}$ \& HFA-FHA, Legal Requirements in the Closing of Section 213 Managearent and Sales Type Projects Involving Insurance of Advances 15 (March 1, 1957).

272. The maximum mortgage amount, $\$ 12,500,000$, "is subject to reduction by an amount equal to the capitalized value of the ground rent in the event the mortgage is on a leasehold estate rather than on a fee simple holding." 24 C.F.R. $\$ 241.7$ (h) (Supp. 1958). This limitation is not significant, however. See note 83 supra. Of course, the down-payment cannot be reduced below the FHA minimum- $5 \%$ on the first $\$ 9,000$ and $25 \%$ on the balance. See N.Y. Times, July 2, 1957, p. 34, col. 7.

273. For examples of the techniques referred to in this paragraph, see Knolls Co-op. Section No. 1, Inc. v. Hennessey, 1 Misc. 2d 1001, 148 N.Y.S.2d 669 (Sup. Ct. 1955), modified, 1 App. Div. 2d 945, 150 N.Y.S.2d 600 (1956), aff'd, 2 N.Y.2d 514, 161 N.Y.S.2d 404, 141 N.E.2d 802 (Sup. Ct. 1957) ; Northridge Co-op. Section No. 1, Inc. v. 32d Ave. Constr. Corp., 207 Misc. 164, 136 N.Y.S.2d 737 (Sup. Ct.), modified, 286 App. Div. 422, 142 N.Y.S.2d 534 (1955), aff'd, 2 N.Y.2d 514, 161 N.Y.S.2d 404, 141 N.E.2d 802 (1957); Nostrand Gardens, Inc. v. Roche, N.Y.L.J., June 20, 1958, p. 9 (N.Y. Sup. Ct., June 19, 
would often organize a cooperative corporation and appoint himself and his agents as directors. The corporation would then obtain an FHA commitment to insure the future project. Subsequently, in varying order of sequence, the directors would contract with a corporation controlled by the sponsor for the construction of the building, arrange for the purchase or lease of the land from another controlled corporation, and sell stock to the prospective cooperators. As a result of his position on both sides of the bargaining table, the sponsor would derive exorbitant profits from the land and the construction. In addition, the cooperators (stockholders) were usually prevented from organizing and electing new corporate directors until the construction was essentially completed and paid for. Payment on the building contract was thereby assured no matter how defective the performance.

At first, the FHA interposed few obstacles to this process of self-dealing. .74 $^{27}$ FHA regulations required that, prior to issuing the mortgage insurance, the agency approve the land lease or sale and both the construction contract and performance thereunder. ${ }^{275}$ These functions were usually discharged with inflexible ineptitude. ${ }^{276}$ For example, in passing on the validity of the ground rent for the unimproved land, the FHA mechanically approved any annual rate within four per cent of the value which the land would have when the apartment building was completed. ${ }^{277}$ Simliarly, the FHA countenanced by-

1958) ; Clearview Gardens First Corp. v. Weisman, 206 Misc. 526, 13 N.Y.S.2d 288 (Sup. Ct. 1954), aff'd, 285 App. Div. 927, 139 N.Y.S.2d $\$ 81$ (1955) ; Clearview Gardens First, Fourth, Fifth and Sixth Corp. v. Weisman, N.Y.L.J., Aug. 26, 1957, p. 11, col. 7 (N.Y. Sup. Ct. 1957) ; Clearview Associates, Inc. v. Clearview Gardens First Corp., S Misc. 2d 470, 168 N.Y.S.2d 432 (Sup. Ct. 1957) ; Mitchell Gardens No. 3 Co-op. Corp. v. Third B N Associates, Inc., 5 Misc. 2d 454, 162 N.Y.S.2d 152 (Sup. Ct. 1957), N.Y.L.J., May 15, 1957, p. 11, col. 3; Hearings Pursuant to S. Res. 229 Before the Senate Committee on Banking and Currency, 83d Cong., 2d Sess., pt. II, at 1186 (1954). These cases under $\S 213$ bear a striking resemblance to controversies over excessive builder profits which arose in the 1930's. See, e.g., 50 East 75th St. Corp. v. Commissioner, 78 F.2d 158 (2d Cir. 1935); Schaffer v. 8100 Jefferson Ave. E. Corp., 267 Mich. 437, 255 N.W. 324 (1934).

274. The FHA acted solely as a mortgage insurer, without considering the interest of the cooperators unless it involved the security of the mortgage. See Clearview Associates, Inc. v. Clearview Gardens First Corp., supra note 273; Clearview Gardens First, Fourth, Fifth and Sixth Corp. v. Weisman, supra note 273; Knolls Co-op. Section No. 1, Inc. v. Hennessey, supra note 273; Nostrand Gardens, Inc. v. Roche, supra note 273.

275. Brief for Defendant-Appellants, Knolls Co-op. Section No. 1, Inc. v. Hennessey, 2 N.Y.2d 514, 161 N.Y.S.2d 404, 141 N.E.2d 802 (Sup. Ct. 1957); Northridge Co-op. Section No. 1, Inc. v. 32d Ave. Constr. Corp., 286 App. Div. 422, 142 N.Y.S.2d 534 (1955), aff'd, 2 N.Y.2d 514, 161 N.Y.S.2d 404, 141 N.E.2d 802 (1957).

276. The FHA permitted inadequate builder indemnity contracts, Hearings Purstant to $S$. Res. 229, supra note 273 , at 1197 ; overestimated income and underestimated carrying charges, $i d$. at 1189, 1204; conducted inadequate inspections, $i d$. at 1193, 1194, 1206; and failed to insist upon sponsor disclosure of self-dealings, id. at 1206, 1211, cf. Grace v. Dry Dock Savings Bank, 3 App. Div. 2d 556, 162 N.Y.S.2d 381 (1.957) (brother of FHA official, hired to procure FHA insurance, denied brokerage fee).

277. Clearview Gardens First, Fourth, Fifth and Sixth Corp. v. Weisman, N.Y.I.J., Aug. 26, 1957, p. 11, col. 7 (N.Y. Sup. Ct. 1957) ; Nostrand Gardens, Inc. v. Roche, N.Y. 
laws which prohibited the cooperators from organizing the cooperative corporation until after they had moved into the building. ${ }^{278}$

\section{The Courts' Approach}

Sponsor profiteering and self-dealing became so widespread that, as of December 1957, approximately one half of the section 213 co-ops in New York had started suits against their respective sponsor-directors for breach of fiduciary duty. ${ }^{279}$ Although most of the suits were settled out of court, ${ }^{280}$ several resulted in judicial decisions which firmly established the "time distinction" doctrine of sponsor-director fiduciary liability. ${ }^{281}$ Specifically, the leading case of Northridge Co-op. Section No. 1, Inc. v. 32nd Ave. Constr. Corp. ${ }^{282}$ ruled that, with respect to dealings occurring before the time that any cooperator subscribed for stock in the cooperative, the sponsor-director's duty was limited to disclosing those dealings to the cooperators when they subscribed. ${ }^{283}$ As for post-subscription activities, the sponsor-director was held to a strict fiduciary duty to account for any unreasonable profits gained through self-dealing.

Attorneys for the cooperators have predicted that the Northridge "time dis-

L.J., June 20, 1958, p. 9 (N.Y. Sup. Ct., June 19, 1958) ; Hearings Purstant to S. Res. 229 , supra note 273 , at 1180 .

278. Knolls Co-op. Section No. 1, Inc. v. Hennessey, 1 Misc. 2d 1001, 148 N.Y.S.2d 669 (Sup. Ct. 1955) ; Nostrand Gardens, Inc. v. Roche, supra note 277.

279. Ennis, Co-op Tenants Sue Project Builders, N.Y. Times, Dec. 1, 1957, § 8 (Real Estate), p. 1, col. 8; Ennis, Revision to Curb Abuses in Co-ops, N.Y. Times, Dec. 8, 1957, \$ 8 (Real Estate), p. 1, col. 7.

280. See authorities cited in note 279 supra. See also N.Y. Times, June 21, 1958, p. 40, col. 5. The suits resulted from the efforts of a few individuals. See Hearings Purstiant to S. Res. 229 , supra note 273 , at 1207 . They were brought on a contingent fee basis. Id. at 1190.

281. See cases cited in note 273 supra.

282. 2 N.Y.2d 514, 151 N.Y.S.2d 404, 141 N.E.2d 802 (1957).

283. The Northridge and Knolls (supra notes 273,278 ) decisions on appeal were consolidated into one opinion, supra note 282 . The limited fiduciary duty of the sponsordirectors was based on "promoter" cases, e.g., Old Dominion Copper Co. v. Lewinsohn, 210 U.S. 206 (1908), cited 2 N.Y.2d at 521, 161 N.Y.S.2d at 411, 141 N.E.2d at 807 , as holding that prior to the sale of stock no one is legally interested except the organizers. The builders argued that the cooperators, in subscribing to the stockholder subscription agreements, charter, and by-laws, had committed themselves to be contractually bound by FHA approval of the construction and lease contracts. However, the court held the FHA's approval to constitute action of an insurer only, not that of an agent binding on the cooperators. 2 N.Y.2d at 528-34, 161 N.Y.S.2d at $413-17,141$ N.E.2d at 809-12. The builders also argued that the court was without jurisdiction since, by reducing the accepted cost of the project, it would, in effect, be revising a federal administrative determination. The court likewise rejected this argument, noting that, to the contrary, a decision in favor of the cooperators would aid the FHA by increasing the value of the mortgage security in proportion to the total co-op debt through a reduction of that debt. 2 N.Y.2d at 528-34, 161 N.Y.S.2d at $413-17,141$ N.E.2d at $809-12$. 
tinction" doctrine will work to eliminate self-dealing. ${ }^{284}$ Possibly this prediction stems from the fact that, under FHA rules, a mortgage cannot be insured and construction begun until ninety per cent of the individual apartment units have been sold. ${ }^{285}$ The promoters will thus occupy a fiduciary position during the construction period. ${ }^{286}$

Nevertheless, the cooperative corporation as directed by the sponsors can still enter into the construction and land-sale (or lease) contracts prior to marketing any stock to the future cooperators. The duty of the sponsor-directors with respect to their most essential activities can therefore be easily restricted to disclosing, at the time stock is subscribed for, the full details of those activities. ${ }^{287}$ Even though this requirement may cause the sponsor's dual position to be publicized, it should not prevent him from negotiating contract terms with himself which will give him exorbitant profits. The present housing shortage hardly disposes a potential cooperator to refuse an apartment because of the sponsor's self-dealing. ${ }^{288}$ In fact, the cooperator probably would not recognize an excessive construction price, for home purchasers commonly have had little experience with real-estate transactions. ${ }^{289}$ Furthermore, while a prospective cooperator may have some knowledge about the cost of building a house, he will doubtless lack the expertness to ascertain the proper cost for a large, multifamily dwelling. ${ }^{290}$ Unlike the middle-income buyer of a single home-who usually can inspect the house he intends to buy (or a duplicate) prior to purchase-most prospective cooperators can only examine blueprints

284. See N.Y. Times, June 29,1958 , § \& (Real Estate), p. 1, col. 8, p. 6, col. 5 (discussing Weisman case cited note 286 infra, which interprets Northridge).

285. See Northridge Co-op. Section No. 1, Inc. v. 32d Ave. Constr. Corp., 286 A.pp. Div. 422,142 N.Y.S.2d 534 (1955) ; Clearview Associates, Inc. v. Clearview Gardens First Corp., 8 Misc. 2d 470, 168 N.Y.S.2d 432 (Sup. Ct. 1957). See note 312 infra.

286. See Clearview Gardens First, Fourth, Fifth and Sixth Corp. v. Weisman, N.Y. L.J., Aug. 26, 1957, p. 11, col. 7 (N.Y. Sup. Ct. 1957) (interpreting Northridge).

287. In Clearviez, supra note 286 , the court indicated that disclosure requirements have specific reference to the sponsor-builder's dual position, not to the contract terms alone.

288. The middle-income family is often forced by the housing shortage to take available housing when the cost is more than it would have been had the sponsor-builder's profit not been excessive. The New York courts, which established the "time distinction" rule, have recognized that a shortage exists, but refuse to give it special weight in defining the sponsor-builders' fiduciary duty. See Nostrand Gardens, Inc. v. Roche, N.Y.L.J., June 20, 1958, p. 9 (N.Y. Sup. Ct. 1957); Northridge Co-op. Section No. 1, Inc. v. 32d Ave. Constr. Corp., 286 App. Div. 422, 434, 142 N.Y.S.2d 534, 546 (1955) (dissenting opinion). See also Clearview Associates, Inc. v. Clearview Gardens First Corp., 8 Misc. 2d 470, 168 N.Y.S.2d 432 (Sup. Ct. 1957).

289. Fisher, op. cit. supra note 264 , at 45. See also ReEve, The Influence of the Mímtropolis on the Concepts, Rules and Instituttons Relating to Property 187 (1954); Marks \& Marks, Coercive Aspects of Housing Cooperatives, 42 ILc. L. Rev. 728, $730 \mathrm{n} .7$ (1948).

290. Even the experts may have some trouble in this respect. See North, Multifamily Housing-Appraising Today's Cliff Dwellings, 23 AppraISAL J. 190, 194 (1955). 
of their future dwellings, because of the FHA rule requiring ninety per cent subscription before construction begins. ${ }^{291}$

\section{The FHA's Approach}

Before the "time distinction" doctrine was enunciated by the courts, the FHA and Congress had begun to formulate rules designed to prevent sponsor-director profiteering. ${ }^{292}$ Every prospective cooperator must be given an FHA-approved information bulletin before he purchases his stock. ${ }^{203}$ In addition, every builder-sponsored co-op is required to employ an independent attorney who represents the cooperators during contract negotiations, and an independent architect who supervises construction. ${ }^{204}$ Under this system, the attorney appoints an independent board of directors to remain in office until a sufficient number of apartments have been sold; the stockholders then elect their own board. ${ }^{295}$

As a third precaution, the FHA permits only a cost-plus-fixed-fee construction contract to be used whenever an identity of interest exists between the cooperative corporation or its agents and the general contractor. ${ }^{200}$ At

291. See, e.g., Hearings Pursuant to S. Res. 229, supra note 273 , at 1216-1S.

292. Although the cooperator suits were started in 1953, see authorities cited note 279 stipra, none were decided until 1955, see authorities cited note 273 supra. FHA precautionary measures were instituted prior to 1954. Letter from Tom L. Davis, Acting Chief Counsel, Cooperative Section, Legal Division, FHA, to the Yale Law Joumal, Dec. 2, 1958, on file in Yale Law Library.

293. H \& HFA-FHA, Legal Requirenents in the Closing of Section 213 Management and Sales Type Projects Involving Insurance Upon Completion 9 (May 1, 1957) ; see FHA, Model Form of Information Bulletin (Form No. 3242, 1957).

Disclosure is a requirement long demanded by those interested in protecting the cooperator. See Note, 61. HARv. L. Rev. 1407, 1411 n.29 (1948) ; N.Y. Times, April 11, 1957, p. 63, col. 4 (proposed bill would require owners of government-insured apartments to make records available to the public upon seeking permission to raise rent). Even if the FHA rule were not in effect, state blue-sky laws might require similar builder-sponsor disclosure. See Anderson, Cooperative Apartments in Florida: A Legal Analysis, 12 U. MIAMI L. REv. 13, 18-21 (1957). But see State v. Silberberg, 166 Ohio St. 101, 139 N.E.2d 342 (1956) (cooperative-apartment stock not "securities" within meaning of Ohio blue-sky law).

294. Letter from FHA, supra note 292; Ennis, Revision to Curb Abuses in Co-ops, N.Y. Times, Dec. 8, 1957, \& 8 (Real Estate), p. 1, col. 7, p. 6, col. 6; Procendings, 1958 Cooperative Housing Conference 50; see H \& HFA-FHA, Legal Reguirenents in the Closing of Section 213 Managearent and Sales Type Projects Involving InSURANCE OF AdvanCES 21 (Feb. 1, 1958) (clause for independent architect certificate).

295. Ennis, supra note 294; N.Y. Times, May 11, 1958, \& 8 (Real Estate), p. 1, col. 3; Co-op Activity \& Housing News, May 1958, p. 5, cols. 1-2; H \& HFA-FHA, ILgaL Requirearents in the Closing of Section 213 Management and Sales Type Projects Involving Insurance of Advances 8 (March 1, 1957).

296. 24 C.F.R. $\$ 241.34$ (Supp. 1958). When an identity of interest exists between the cooperative corporation or its agents and the subcontractor, the "general contractor must certify in a form prescribed by the commissioner . . . that the amounts paid to such subcontractor or material supplier were not more than the rate prevailing in the locality for similar types labor and materials." Id. \$241.34(c). 
first, "identity of interest" was broadly construed. A builder who advanced insurance fees or provided free architectural plans was classified as financially interested in the cooperative. ${ }^{297}$ Builder-sponsors immediately took their complaints to Congress, where they objected to the cost-plus contract on four grounds: possible arbitrary and unfair determinations of allowable cost without a builder right of appeal; the alleged invitation to cooperators to "second guess" and challenge the builder's cost; removal of the incentive for cost savings; and the absence of a final cut-off date beyond which certified costs would be incontestable. ${ }^{298}$ In response, the House Committee on Banking and Finance suggested to the FHA that, inasmuch as the cooperative had its own independent attorney and architect, identity of interest could be narrowly defined without adversely affecting the cooperators' rights. ${ }^{209}$

If followed, the Committee's advice will prove as misguiding as it is misguided. The independent-attorney requirement cannot be relied upon to protect the cooperators' rights, for the attorney is of questionable independence. Although he must be approved by the FHA as to his good standing in the legal profession, he may have been nominated by the sponsor. ${ }^{300}$ Moreover, the attorney, representing a group of not-yet-selected cooperators, is in no position to equalize the cooperative's bargaining power vis-à-vis the sponsor. In this framework, the acuteness of the housing shortage and the necessity that the cooperative be built despite the sponsor's excessive profits will prove decisive bargaining weapons. Since the FHA's "identity of interest," whether broadly or narrowly defined, therefore seems inadequate, that standard should be abandoned altogether. Instead, a cost-plus contract should be required for every builder-sponsored co-op.

The builders' allegations concerning the cost-plus contract retail shortcomings which are either nonexistent, insubstantial or easily remedied. Past FHA regulatory decisions indicate that the arbitrary disallowance of costs is unlikely. ${ }^{301}$ Furthermore, the fair market value of property prior to improvement can be ruled on by the FHA at the time the land is leased or sold..$^{302}$ And,

297. H.R. REP. No. 2963, 84th Cong., 2d Sess. 56 (1956).

298. Id. at 57.

299. Ibid. The Committee stressed the importance of builder sponsorship to the success of the $\S 213$ program.

The FHA has retained the same broad definition of identity of interest. See FHA, Section 213-Cooperative Housing, p. 2 (Release No. CH-146, March 14, 1956). Although promulgated prior to the release of H.R. REP. No. 2963, supra note 297 , the definition of identity of interest contained in Release No. $\mathrm{CH}-146$ is still in effect. See Letter from FHA, supra note 294. Administrative application may have varied, however.

300. See Ibid.

301. See notes 171-74 supra and accompanying text. See also Stern, Building Standards, N.Y. Times, Dec. 6, 1958, $\$$ (Real Estate), p. 1, col. 6, p. 4, cols. 6-7 (FHA revises its construction standards so as not to impose an unduly harsh burden upon builders). But sec Business Week, Sept. 2S, 1955, p. 207.

302. See Section 213-Cooperative Housing, supra note 299, at 9; authorities cited note 270 supra. 
since the FHA has clearly defined the construction costs which may be disallowed-rebates, discounts or kickbacks, ${ }^{303}$-the builder can anticipate any disallowances. If, however, the FHA should exercise its power arbitrarily, judicial review is available ${ }^{304}$ more informally, the FHA might establish a board of claims. In any event, the possibility of arbitrary action exists under a lump-sum as well as a cost-plus contract.305 Similarly, cooperator "second guessing" of the contractor's price could occur in connection with either type of agreement. ${ }^{206}$

The lack of any incentive to perform economically under a cost-plus contract presents a problem which is only slightly more serious. Its solution lies in the proper utilization of the FHA-approved, estimated actual cost, known as the "upset price." 307 Provision should be made for the cooperative and the builder to share equally that amount by which the upset price exceeds final actual cost. ${ }^{308}$ The builder would thus have an incentive to effect savings; and inspection by the FHA and independent architect would insure that savings did not stem from inferior materials or faulty performance.

The most significant of the builder objections to the cost-plus contract is the absence of a final cut-off date beyond which certified costs would be incontestable. This deficiency is readily correctable through administrative action. The FHA could adopt a regulation to the effect that the builder's certification of cost could not be reopened once approved by the FHA, unless

303. Section 213-Cooperative Housing, supra note 299, at 7. See also 70 Stat. 1095 (1956), 12 U.S.C. $\$ 1715$ (Supp. V, 1958) (same standards for mortgagor's cost certificate). For a discussion of this standard, see North, Multifamily Housing-Appraising Today's Cliff Dwellings, 23 Apprarsal J. 327 (1955).

304. See, e.g., Loftus v. Mason, 240 F.2d 428 (4th Cir.), cert. denicd, 353 U.S. 949 (1957). On the problems involved in establishing jurisdiction over the FHA, see Garden Homes v. Mason, 238 F.2d 651 (1st Cir. 1957) ; Waylyn Corp. v. United States, 231 F.2d 544 (1st Cir. 1956) ; Fleetwood Acres v. FHA, 171 F.2d 440 (2d Cir. 1948).

305. All builders, whether under lump-sum or cost-plus contracts, are subject to FHA review as to compliance with construction standards. FHA, Construction Contract-"Cost Plus," art. I(b) (Form No. 3223) ; FHA, Construction Contract-"Lump Sum," art. I(b) (Form No. 3222) ; 24 C.F.R. $\$ 241.4$ (e) (Supp. 1958) (FHA inspection fee $\$ 5$ per $\$ 1,000$ of commitment). Moreover, consistent violation of FHA standards may result in denial of the builder's future right to participate in FHA programs. National Housing Act $\$ 512,68$ Stat. 610 (1954), as amended, 12 U.S.C. $\$ 1731$ (a) (Supp. V, 1958). See Madway v. Mason, P-H Feneral Aids to Financting II 47669 (D.D.C. 1955).

306. If cooperators lack the expertise to judge a builder's proficiency but, nevertheless, intend to question his honesty, the form of the contract will not prevent them from doing so. In fact, a cost-plus contract, by breaking down the individual elements composing the builder's price, may sometimes serve to quiet their fears that he is making an exorbitant profit.

307. See 24 C.F.R. $\$ 241.35$ (Supp. 1958). The upset price presently serves only as an upper limit beyond which the builder is not reimbursed for actual costs.

308. Such an incentive clause is presently available under the FHA cost-plus contract, but is not compulsory. Section 213-Cooperative Housing, supra note 299, at 2. It has been used effectively in the past. See Parker, Cooperative Housing, Mid-1950, 73 MontrIY LAB. REv. 258, 261 (1951). 
fraud or material misrepresentation were at issue. ${ }^{309}$ Congress has already enacted a similar provision which, through inadvertence, protects only those builders who (as in many rental housing projects) are also mortgagors. ${ }^{310}$

In sum, an absolute requirement of a cost-plus contract in every instance of builder sponsorship need not discourage the construction of cooperative apartments by entrepreneurs seeking normal profits. The only substantial deterrent would be the FHA's failure to allow profits which are competitive as compared to those available in other areas of residential construction. ${ }^{311}$ The cure for this difficulty is self-evident.

An absolute cost-plus contract rule would also be consistent with Congress' response to the FHA requirement that construction may not begin until at least ninety per cent of the units in a cooperative are sold. ${ }^{312}$ The FHA insists upon this standard as a means of insuring the cooperative's success. ${ }^{313}$

309. Compare 70 Stat. 1095 (1956), 12 U.S.C. $\$ 1715$ (r) (Supp. V, 1958).

310. Section 109 of the National Housing Act requires that the cooperative mortgagor file a certificate of cost prior to the final issuance of the mortgage insurance. 70 Stat. 1095 (1956), 12 U.S.C. $\$ 1715$ ( $r$ ) (Supp. V, 1958). The certificate is utilized to ensure that the ratio of loan to replacement cost does not exceed the maximum limit of $90 \%$ in nonveteran projects or $95 \%$ in veteran projects. See 24 C.F.R. $\$ 241.33$ (Supp. V, 1958) ; H \& HFAFHA, Legat Reguirements in the Closing of Section 213 Managenient and Sales Type Projects Involving Insurance of Advances 32-33 (Feb. 1, 1958). In 1956, Congress made the FHA's approval of the certificate incontestable except for fraud or material misrepresentation on the part of the mortgagor. 70 Stat. 1095 (1956), 12 U.S.C. $\$ 1715$ ( $r$ ) (Supp. V, 1958). The intent of Congress in enacting the incontestability clause was to aid builders. H.R. REP. No. 2363, 84th Cong., 2d Sess. 15 (1956). Apparently, however, Congress overlooked the fact that in the $\$ 213$ co-op, unlike other types of multifamily projects, the builder and mortgagor are not the same entity; the incontestability clause mentions the mortgagor's certificate without making any reference to the builder's certificate, which is a separate instrument. See Section 213-Cooperative Housing, supra note 299, at 3 ("In normal rental housing operations . . . sponsors, builders, owners, and mortgagors ... are one and the same."). Thus, although the mortgagor's certificate contains the price charged by the builder, and the FHA must necessarily review the builder's certificate of costs under a cost-plus contract before approval, see 24 C.F.R. $\$ 241.36$ (b) (Supp. 1958) (builder's certificate must accompany mortgagor's certificate), the incontestability clause as drafted protects only the cooperative mortgagor.

311. The allowed fee on a cost-plus-fee contract varies with the geographical location of the project. Ietter from FHA, supra note 292. One report indicates that builders have been allowed a 5 to $9 \%$ profit in the New York area. Ennis, Revision to Cutrb Abuses in Co-ops, N.Y. Times, Dec. \&, 1957, § 8 (Real Estate), p. 1, col. 7, p. 6, cols. 6-7. That rate is uncompetitive; New York builders usually demand 10 to $15 \%$. Interview with a New York City attorney, Dec. 1, 1958.

312. H \& HFA-FHA, Legal Reguirenients in the Closing of Section 213 MaNagentent and Sales Type Projects Involving Insurance of Advantes 25 (Feb. 1, 1958).

The FHA prefers that all units be sold before the insurance is granted. H.R. REP. No. 2963, supra note 297 , at 58 . But it will accept the sale of $90 \%$ of the units. See LEGAL REQUIREMENTS, op. cit. supra, at 25; FHA, Mortgagor's Certificate, II 12 (Form No. 3212, 1954). The requirement of $100 \%$ enrollment is similar to that used in New Zealand under the government-supported, group-housing program. See 31 New ZEALAND L.J. 109 (1955).

313. See 1957 Senate Hearings 940 (noting the advantages of this rule). 
Some sponsor-builders state, however, that the requirement causes the builder to spend too much time on preliminary activities, that it creates an excessive time lag between the first stock subscriptions and the last, and that original purchasers lose interest during this interval. ${ }^{314}$ These arguments evoked the enactment of section 213 (a) (3), which authorizes a departure from the ninety per cent regulation under rigid, specified conditions designed to protect the cooperator. ${ }^{315}$ In addition, the builder-sponsor must then operate under a costplus contract, since 213 (a) (3) presumes that an identity of interest is present between him and the mortgagor corporation. ${ }^{316}$

\section{Cooperators}

Given lender and sponsor participation, the section 213 program can succeed only to the extent that middle-income cooperative apartments remain in demand. Currently, most of the demand has three sources-the desire for home ownership, the convenience of urban (as opposed to suburban) living and the relative cheapness of the co-op.

Cooperatives are advertised as a form of home ownership, ${ }^{317}$ and the cooperator usually considers himself to have "purchased" an apartment,"

314. See H.R. REP. No. 2963, op. cit. supra note 297, at 58; Co-op Activity \& Housing News, May 1958, p. 4, cols. 5-6.

315. 70 Stat. 1094 (1956), 12 U.S.C. $\$ 1715$ (e) (a) (3) (Supp. V, 1958). The builder may begin construction prior to the sale of any stock if he complies with regulations similar to those applied under the closely supervised $\$ 207$ program, which include limitations on mortgage terms, rate of return and capital structure. See ibid.; 24 C.F.R. $\$ 241.7$ (Supp. 1958) (limiting the amount of the loan to $85 \%$ of replacement cast) ; $\$ 241.31$, incorporating $\S 232.19$ (b) (limiting rate of return); and $\$ 232.19$ (e) (regulating rents). See also Hearings on Independent Offices Appropriations for 1958 Before a Sub-Cammittee of the Senate Committee on Appropriations, 85th Cong., 1st Sess. 1795 (1958). To date, $\S 213$ (a) (3) has been used infrequently. Proceedrngs, 1958 Cooperatrve Housing ConFERENCE 43. It may be assumed, however, that the FHA will be as strict in applying these standards as it has been with similar standards under $\$ 207$. See Middle-Income Housing: The Big City's Problem, Time, Sept. 16, 1957, p. 104 (FHA suspiciously administers its new $\$ 207$ program, sets extremely rigid standards). Of course, the cooperators who eventually purchase the project from the builder may refinance under the more liberal terms of $\$ \$ 213(a)(1)$ and $213(b)$.

316. 24 C.F.R. $\$ 241.31$ (b) (Supp. 1958), relating to $\$ 213$ (a) (3) projects, incorporates a $\$ 207$ regulation, 24 C.F.R. $\$ 232.25$, which requires a cost-plus contract whenever the mortgagor has "any interest in the builder." Since the mortgage under $\$ 213$ (a) (3) is granted to the builder-sponsor rather than the co-op corporation, there is no doubt as to the mortgagor's financial interest in the builder. See FHA, Section 213Cooperative Housing (Release No. CH-146, March 14, 1956).

317. See, e.g., N.Y. Times, Nov. 2, 1958, $\$ 8$ (Real Estate), p. 23, col. 6 ("cooperative plan provides security, equity, and pride of ownership"); id., p. 23, col. 8 ("buy an apartment") ; id., p. 24, col. 8 (enjoy "cooperative ownership"). Even the FHA advertises the co-op as a "form of home ownership." See FHA, Model Form of Information Bulletin (Form No. 3242, 1957).

318. Isaacs, To Buy or Not to Buy: That is the Question ... What is a Cooperative Apartment?, 13 Recopd of N.Y.C.B.A. 203, 208 (1958); see Ennis, Cooperative Hous- 
fulfilling the common urge to own one's residence. ${ }^{319}$ Although the cooperator may not actually possess that bundle of rights traditionally associated with ownership, ${ }^{320}$ he enjoys many which distinguish ownership from tenancy. $\mathrm{He}$

ing-I, N.Y. Times, Dec. 22, 1957, \$ \& (Real Estate), p. 1, cols. 5-6. See also ProceEdrngs, 1958 Cooperative Housing Conference 14, 20, 47 (founder and manager of the Amalgamated Project, referring to cooperators as "owners") ; 1958 Sentate Hearings 587 (President of Cooperative League, noting that $\$ 213$ has extended the principle of home ownership).

319. Home ownership is a most sought-after objective of middle-income families. See Festinger, Schacter \& Back, Soctal Pressures in Informal Groups 27 (1950) (28\% of the people interviewed listed home ownership in itself as a reason for satisfaction with their places of residence); Savings \& Loan News, June 1953, pp. 16, 18 (22\% of the people interviewed preferred purchasing over renting because of the "ideal of home ownership"); Straus, Two-Thirds of a NatTon 71-73 (1952).

Commentators have long promoted home ownership as a great American ideal. See, e.g., Hale, Workingaren's Homes 8-10 (1874); Riss, The Peril and the Preservation of THE HOME (1903). For examples of more recent emphasis on home ownership, see Abrams, U.S. Housing: A Nezu Program, New Leader, Jan. 13, 1958, § 2, p. 5; 21 SoL. 139 (1954).

The federal government has also promoted home ownership. See, e.g., U.S. PRESIDENT'S Conference on Honse Building and Home Ownership (Dec. 14, 1931) (Address of Secretary of the Interior) ("Home ownership should be a possibility at some time in life of every thrifty family."); 1957 Senate Hearings 662.

Since 1940, the percentage of home ownership has expanded to its highest point in U.S. history-almost a plurality. See H \& HFA, Housing IN rHe UnNTEd States 18-19 (1955); StraUs, op. cit. supra at 77 n.1; 1957 Senate Hearings 662 (during last 17 years, the families renting have increased by 1.7 million; those owning homes by 14.5 million). See generally Fisher, Urban Real Estate Markets: Characteristics and Financing $38-42$ (1951).

320. For the usual determinants of ownership, see Sims, A Study of the Bundle of Rights Constituting Ozwnership of Land, 9 ALA. L. Rev. 243 (1948); Colean, Changing Attitudes Tozward Property Ozmership and Mortgage Finance, 12 LAw \& ConteMr. ProB. 25 (1947).

Although all "owners" are limited in the power they may exercise over their property by the effect of their acts on surrounding owners, Cross, The Diminishing Fee, 20 LAw \& Contearp. Pвов. 517, 518 (1955), the cooperator's control over his apartment unit is especially restricted by his relationship with his neighbors. As stated by one author,

$[\mathrm{H}] \mathrm{e}$ has given up some of his possessory rights to acquire the assurance of congenial neighbors ... [H] lacks the freedom of the home owner in deciding what services are to be had in the building, what loans are to be secured by mortgages, what expenses are to be undertaken. But he has a far larger voice in this connection than would the tenant of an apartment house. The greatest difference, of course, between cooperative ownership of an apartment and full ownership of a home lies in the fact that the home owner's security of possession depends exclusively upon himself and his own finances whereas the security of the cooperative owner's possession depends in part at least upon payment by others of the expenses of operation, including mortgage interest and amortization. ... .

Isaacs, To Buy or Not to Buy: That is the Question ... What is a Cooperative Apartment?, 13 RECORd of N.Y.C.B.A. 203, 208-09 (1958). See McCullough, Comoperative Apartments In Illinois, 26 CHI.-Kent L. Rev. 303, 321-24 (1948); Abrams, supra note 319 , at 5 (separating types of land tenure).

For a survey of the dispute among commentators and courts as to the cooperator's classification within the various tenures of ownership, see REEvE, THE INFLUENCE of THE 
has an equity interest which can be sold, permanence of tenure, freedom in decorating his home, and a voice in managing the property. ${ }^{321} \mathrm{He}$ may also seek out the cooperative as the best available place to live within a reasonable distance of a city's center. The fringes of the city and nearby, well-established suburbs have become more attractive residentially than the newer suburbs because of the latter's comparatively unstable taxes and inadequate school facilities, not to mention the difficulties of commuting. ${ }^{322}$ Land prices in less remote residential areas have therefore risen and dictated the erection of multiunit dwellings. ${ }^{323}$

On the other hand, many section 213 cooperators would probably prefer to rent rather than make a substantial cash outlay for a down-payment, or to own a single home and not be compelled to associate, personally and financially, with neighbors. ${ }^{324}$ Their preference may be frustrated, however, by the increase in the cost of housing, which, since 1949, has been over fifty per cent greater than the increase in the cost of other necessities. ${ }^{325}$ Thus, economic

Metropolis on the Concepts, Rules and Institutions Relating to Property 199-203 (1954).

321. Isaacs, supra note 318 , at 208 . The equity interest has been stressed in particular. Proceedings, 1958 Cooperative Housing Conference 2. As to the importance of this factor in an era of high mortgages, see Stern, Equity v. Mortgage, N.Y. Times, Sept. 8, 1957, $\$ 8$ (Real Estate), p. 1, cols. 6-7. See also 1957 Senate Hearings $666-67$, tables IIIIV (Home Builders Association included $\S 213$ co-ops in list of multifamily projects but excluded them from list of rental projects).

322. See N.Y. Times, May 4, 1958, $\$ 8$ (Real Estate), p. 1, col. 2 (suburbanites shift to fringes of city); see also id., March 24, 1957, p. 1, col. 8; House \& Home, April 1958, p. 103. On the problem of rapidly increasing real estate taxes in suburbs, see North, Multifamily Housing-Appraising Today's Cliff Dwellings, 23 AppraIsar. J. 327, 331 (1955) (smail towns and suburbs wait until enough new housing is attracted and then begin to raise assessments). On the difficulties of commuting, see Fordham, Local Government's Power to Provide and Finance Parking Facilities, 5 Trafric Q. 369 (1951) ; Levin, Parking Facilities as Public Utilities, 29 Chr.-Kent L. Rev. 295 (1951); Foster, Anterica's Off-Street Parking Problems, 23 Appraisal J. 63 (1.955). The recent refusal of people to move farther and farther from the center of a city is in marked conflict with the prior trend. See, Whyte, Are Cities Unamerican?, in 29 Reference Shelf 136 (No. 6, 1957). For a predicted return to that trend, see Sigety, Relation of the Highway Program to Housing, Banking, Feb. 1957, p. 41. But see N.Y. Times, April 7, 1958, \& 8 (Real Estate), p. 1, col. 2; U.S. News \& World Report, July 19, 1957, p. 72 (cities' attempts to draw people back).

323. House \& Home, A.pril 1958, p. 103; Hennessey, Cooperative Apartments and Tozen Houses, 1956 InL. L.F. 22 (1956). See also Ennis, Hone Prices Go Up in the Suburbs, N.Y. Times, March 24, 1957, \& \& (Real Estate), p. 1, col. 7. A similar shortage of available residential space contributed to the co-op boom of the $1920^{\prime}$ s. See Taylor, General Business Conditions as They Reflect on the Building Situation, 32 ARCHITECTURAL F. 240 (1920).

324. See generally Hennessey, supra note 323 , at 23 (noting disadvantages of a co-op). See also N.Y. Times, June 29, 1957, \& 8 (Real Estate), p. 1, cols. 2-3 (privacy stressed in single homes).

325. 81 Montely Lab. Rev. 914, 949, 950 (1958). See also Construction Rev., Aug.Sept. 1958, p. 36 (index shows cost of residential construction increased approximately 
exigency alone can induce the middle-income consumer to take advantage of the fact that co-ops provide cheaper housing than most newly-built, FHAfinanced homes or rental apartments. ${ }^{320}$ The co-op's cost advantages are not only those of the homeowner-elimination of landlord profits, ${ }^{327}$ income-tax deductions for the cooperator's proportionate share of mortgage interest payments and real-estate taxes, ${ }^{328}$ savings through careful occupant maintenance

40\% since 1947-1949). For factors causing the increase, see Construction Rev., Feb. 6, 1958, p. 3S; House \& Home, June 1958, p. 39 (increase in price of materials and labor).

326. See 1957 Senate Hearings 940; ProceEdings, 1958 Cooperative Housing ConFERENCE 29. See also H.R. Rep. No. 2363, 84th Cong., 2d Sess. 11 (1956). The savings on costs of financing will approximate $10 \%$. The savings attending co-op construction and operation have been sufficient to permit the construction of a middle-income co-op in Manhattan, one of the most expensive residential areas. Compare Ennis, Co-op Apartment Will Rise Uptowm, N.Y. Times, May 19, 1957, \$ \& (Real Estate), p. 1, col. 1 (monthly assessment $\$ 35$ per room), with Grutzner, Housing Snagged on Income Range, id., Apri1 7,1958 , p. 1 , col. 7 (unsubsidized apartments in Manhattan require rents of $\$ 40$ to $\$ 45$ a room). FHA-financed homes are generally beyond the means of middle-income consumers earning under $\$ 6,000$ per year. The average FHA home costs approximately $\$ 12,800$. House \& Home, Aug. 8, 1958, p. 38; 1957 Senate Hearings 418 (median FHA home for 1956 estimated at $\$ 13,000)$. And, in certain high-cost areas, the average sales price will be far in excess of that amount. See 1957 Senate Hearings 867 (few houses built in New York for less than $\$ 15,000$ ). See also 1958 Senate Hearings 95 (average price of homes in major cities $\$ 15,000$ to $\$ 17,500$ ) ; N.Y. Times, May 19,1957 , $\S 8$ (Real Estate), p. 1 , cols. 1-2. With a 5\% down-payment required by the FHA, the mortgage on most FHAfinanced homes would approximate $\$ 12,000$. Assuming a $5 \mathrm{x} / 2 \%$, 25-year mortgage (average terms on a single dwelling) and that one-fifth of a family's annual income should be spent on housing, the purchaser would need an annual income of $\$ 6,761$ to afford such a house. 1957 Senate Hearings 856; see also 1958 Senate Hearings 763 (table 2). Of course, the requisite income would be reduced by approximately $\$ 900$ if it were assumed, as the FHA does, that one-third of the first $\$ 3,000$ of annual income and one-fifth of the remainder should be spent on housing. See 1958 Senate Hearings 79 (Commissioner of the FHA). But the FHA's estimate is unrealistic. Rupkin, Rent-Income Ratio-Should Formula for Public Housing Be Changed?, J. of Housing, Jan. 1957, pp. 8-9 (U.S. Housing Census of 1950 shows that families earning $\$ 3,000-\$ 3,999$ tend to spend $15 \%$ of their earnings on housing, and families in higher brackets spend an even lower percentage.). The price of rentals is similarly out of reach of middle-income families with less than a $\$ 6,000$ annual income. 22 FHA ANN. REP. 176 (1955) (median cost for $\$ 207$ rentals $\$ 120$ per month; $\$ 130$ for $\S 220$ projects).

327. Flamm, Honsing Co-operatives, 6 Law. GuILd Rev. 590 (1946); 1950 House Hearings 150, 158; S. REP. No. 1286, 81st Cong., 2d Sess. 958 (1950).

Of course, this saving is offset to a slight degree by the income which the cooperator's down-payment would yield if otherwise invested. See Haar, Middle Income Housing: The Cooperative Suare?, 29 Land Econ. 289, 293 (1953).

328. INT. Rev. CODE of 1954, $\$ 216$. The Code permits such deductions to tenant-stockholders of cooperative-housing corporations "having one and only one class of stock outstanding." Id. $\$ 216$ (b) (1) (A). Technically, the $\$ 213$ co-op violates this standard since it has two classes of stock-the common stock issued to the cooperators and the preferred stock issued to the FHA-and that agency has majority voting rights in the event of a violation of the co-op charter. 24 C.F.R. $\$ 241.23$ (Supp. 1958); H \& HFA-FHA, LEGAL Reouirenents in the Closing of Sectron 213 Management and Sales Type Projects Involving InsuRance of AdVANCES 30 (Feb. 1, 1958). On the regulatory provisions for FHA stock, see note 101 supra and accompanying text. But the Treasury Depart- 
which minimizes the charge for repairs and upkeep ${ }^{329}$-but also those of large-scale enterprise. The economies of mass production, ${ }^{330}$ the efficiency of building multifamily residences on a vertical instead of horizontal plane (one basement, less piping, etc.), ${ }^{331}$ and.lower per-dwelling-unit professional fees serve to reduce construction expenses. ${ }^{332}$ Land can be acquired at a lower per-unit cost as a large tract than as individual family lots. ${ }^{333}$ Similarly, a single mortgage requires less servicing than many and hence carries a lower interest rate. ${ }^{334}$ Further cost reductions are available through cooperative

ment has decided to overlook this departure from the language of the Code. Treas. Reg. \$ 1.216-1(c) (1) (1958); Rev. Rul. 120, 1953-2 Cumr. Burl. 130.

Before a specific code provision was enacted, the stockholder in a cooperative apartment building was not permitted to deduct his share of the corporation's interest and taxes. Wood v. Rasquin, 21 F. Supp. 211 (E.D.N.Y. 1937), aff'd per curiam, 97 F.2d 1023 (2d Cir. 1938) ; Holden v. Commissioner, 27 B.T.A. 530 (1933). In 1942, the Internal Revenue Code was amended by adding $\S 23(z)$, Revenue Act of 1942 , ch. 619 , $\S 128$, 56 Stat. 826 (1942) (now INT. REv. CODE of 1954, $\$ 216$ ), permitting the above deductions. Nevertheless, the tax benefits afforded a cooperator are not identical with those granted a home owner. For example, the cooperator probably would not be able to claim a casualty-loss deduction for damage to his apartment; the deductions provided for in $\$ 216$ were expressly limited in their scape. See S. Rep. No. 1631, 77th "Cong., 2d Sess. 51 (1942) ("The general purpose of this provision is to place the tenant stockholders of a cooperative apartment in the same position as the owner of a dwelling house as far as dedictions for interest and taxes are concerned.") (Emphasis added) ; H.R. REP. No. 1337, 83d Cong., 2d Sess. A62 (1954).

329. These savings arise from repairs made by the individual within his apartment. Haar, Middle-Income Housing: The Cooperative Share?, 29 Land Econ. 289, 292 (1953); H.R. REP. No. 1686, 81st Cong., 2d Sess. 21. (1950) ; Senate Comm. on Banking and Currency, Report of the Subcomm. Investigating and Surveying European Housing Programs on Cooperative Housing in Europe, S. Doc. No. 148, 81st Cong., 2d Sess. (1950). And from the better maintenance of general areas stemming from the cooperators' pride of ownership. 1950 House Hearings 150-51; H.R. REP. No. 1686, 81st Cong., 2d Sess. 21 (1950) ; S. REP. No. 1286, 81st Cong., 2d Sess. 21. (1950) ; interview with Cleveland attorney, Oct. 16, 1958. But see Haar, supra at 291.

330. See Haar, supra note 329 , at 290 ; S. Doc. No. 148 , supra note 329 , at 4 . The benefits of mass production are also available in the construction of single homes, provided many units are built simultaneously. Stern, Rival Projects Seek Economies by Combining Many Operations, N.Y. Times, Oct. 27, 1957, § 8 (Real Estate), p. 1, cols. 2-3.

331. Parker, Cooperative Honsing in the United States, Mid-1950, Montrly Lab. REv. 258, 260 (1951).

332. Staff of Subcomis. on Housing \& Rents, Senate Comm. on Banking \& Currency, 81st Cong., 2d Sess., Report on Domestic Cooperative Housing 4 (1950); Haar, supra note 329 , at 290.

333. Report on Domestic Cooperattve Housing, supra note 332 , at 2. In contrast, when single homes are mass produced, additional legal fees are incurred in subdividing the property for individual plots.

334. 1958 Senate Hearings 71-72, 195; Report on Dodrestic Cooperative Housing, supra note 332 , at $98 ; 1950$ House Hearings 158,174 . Partially off setting this advantage is an amortization period longer than that utilized on most single-home mortgages, see note 194 supra, and therefore higher financing costs, see FISHER, op. cit. supra note 319 , at 6772. But see 1958 Senate Flearings 328 (claiming a long amortization period is an outstanding advantage of $\$ 213$ projects). 
action, such as the joint purchasing of fuel, insurance, and utility services by the members of one or more co-ops. ${ }^{335}$

\section{Financial Interdependence: A Key Disadvantage?}

The advantages of the cooperative apartment are offset to a degree by the consequences of vesting title in one entity-the cooperative corporation-and the resultant single mortgage on the entire building. ${ }^{336}$ The corporation's ability to make payments on this mortgage depends upon every member meeting his periodic assessments. ${ }^{337}$ If one cooperator fails to discharge an assessment, the corporation may in turn be unable to discharge the related mortgage payment in full and will, therefore, be in default. ${ }^{338}$ Were foreclosure to ensue, it would be not merely on the apartment unit of the delinquent cooperator but on the entire building. ${ }^{339}$ This financial interrelationship of all members can thus force a solvent cooperator to choose between losing his own apartment and assuming the assessments of insolvent cooperators.

Ordinarily, financial interdependence will not prove a burden to the solvent cooperator except in a period of extremely depressed real-estate prices. ${ }^{340}$ If the market value of the defaulter's stock in the cooperative is greater than the total of his unpaid assessments, his fellow cooperators usually will not have to make good his arrearage. The by-laws of most cooperatives grant the corporation a lien which permits it to sell the defaulter's shares and retain the amount owed. ${ }^{341}$ But when the stock is sold at a price less than that owed,

335. N.Y. Times, Jan. 3, 1958, \& \& (Real Estate), p. 1, col. 8 (New York co-ops form single purchasing agency for supplies, heating equipment, water, etc.); id., Aug. 4, 1957, $\$ 8$ (Real Estate), p. 1, col. 8, p. 6, col. 4 (twenty-three $\$ 213$ co-ops in New York join insurance pool plan; also expect to share resources in purchasing fuel) ; 1950 House Hearings 158 (savings by joint purchasing of utilities).

336. This problem is probably the most frequently mentioned disadvantage of the co-op. See, e.g., 1954 Senate Hearings 981; Isaacs, To Buy or Not to Buy: That is the Question... What is a Cooperative Apartment?, 13 Record of N.Y.C.B.A. 203, 209 (1958) ; 1950 House Hearings 386; cf. Yourman, Some Legal Aspects of Cooperative Housing, 12 LAW \& CONTEMr. Prob. 126, 132 (1947).

337. See Anderson, Cooperative Apartments in Florida: A Legal Analysis, $12 \mathrm{U}$. Miami L. Rev. 14 n.4 (1957).

338. Contingency reserves might be used to pay the delinquent cooperator's assessments, however. See notes 354,358 infra.

339. See co-op foreclosure cases collected in McCullough, Co-operative Apartments in Illinois, 26 ChI.-KeNt L. Rev. 303, 305 n.20 (1948). See also Haar, supra note 332, at 293 n.18.

340. Despite their constant exposition of the dangers involved in financial interdependence, commentators have failed to analyze when and to what extent interdependence actual$1 y$ does affect the cooperator adversely. See, e.g., authorities cited note 336 supra. See also Note, 61 Harv. L. Rev. 1407, 1411, 1418-22 (1948) ; Hennessey, Co-operative Apartments and Town Houses, 1956 ILL. L.F. 22, 33, 37-38; Teitelbaum, Representing the Purchaser of a Cooperative Apartment, 45 ILI. B.J. 420, 423 (1957) ; Anderson, Cooperative Apartments in Florida: A Legal Analysis, 12 U. Mrani L. Rev. 13, 35 (1957).

341. FHA, Model Form of By-Lazws, art. VII, $\$$ (Form No. 3244, 1957) ; Note, 61 HARv. L. REv. 1407, 1418 n.63 (1948); Hennessey, supra note 340, at 27-28, 37-38. 
the nondelinquent cooperators may be forced to bear an additional assessment, although probably an insignificant one. The purchaser of the stock will, as a new cooperator, assume liability for future assessments and will, for this reason, limit the arrearage to assessments occurring before his purchase. ${ }^{342}$ Furthermore, the premium (if any) paid by the purchaser may be kept by the corporation and applied against this arrearage. ${ }^{343}$ Finally, if the defaulter is solvent, his indebtedness can be recouped by a suit under the lease. ${ }^{344}$

Consequences of more moment arise when the delinquent cooperator's stock cannot be sold. Unsalability results whenever the market value of the defaulter's apartment unit is less than the total of all future mortgage assessments on the unit, ${ }^{345}$ since no purchaser would assume a mortgage liability greater than the worth of the item mortgaged. In this situation, the remaining cooperators would have to make good the assessments on the unsold units, lest the receipts of the corporation fall below the amount necessary to meet its mortgage payments. The burden on these cooperators can, however, be reduced. If the defaulter is simply recalcitrant and not insolvent, the corporation can collect his assessments by suing him under the lease. And, if he is insolvent, additional corporate income can be earned by renting his apartment to someone other than a cooperator. But renting cannot completely eliminate the additional payments forced upon the nondefaulting cooperators. Unlike assessments, which must invariably subsume the fixed monthly mortgage payment, rent reflects current market conditions and will be substantially less than the normal assessment charge in periods when the value of cooperative apartments is seriously depressed..$^{\mathbf{4} 6}$

Although the cooperator can always avoid the responsibility of an additional assessment by defaulting, he will rarely do so if the extra payment is within his means. Even when the cost of purchasing or renting a similar dwelling

342. A quick sale of the defaulter's apartment may be facilitated by a joint co-op selling agency. See N.Y. Times, April 27, 1958, $\$ 8$ (Real Estate), p. 11, col. 4 (central information service established for prospective buyers of $\$ 213$ cooperative apartments in New York City area).

343. On the treatment of such an amount in suing a bankrupt cooperator for damages caused by his default, $c f$. Oldden v. Tonto Realty Corp., 143 F.2d 916 (2d Cir. 1944).

344. See Note, 61 Harv. L. Rev. 1407, 1414-15 (1948) ; 4 E. 72nd St. Corp. v. Lowman, 272 N.Y. 451,3 N.E.2d 864 (1936). On the amount of damages which may be collected, see Hawkinson v. Johnston, 122 F.2d 724 (8th Cir.), cert. denied, 314 U.S. 694 (1941). Even if the cooperator is in bankruptcy, a limited recoupment may still be obtained. See 3 Collter, BanKRuptcy $\$ \$ 63.32-.33$ (14th ed. 1957) (priority of lessor under Bankruptcy Act).

345. Market value, in this sense, means the value of the stock interest representing the one unit in the co-op, ignoring any attached debt. Except in most unusual circumstances, the market value will be at least equal to the cost of upkeep, insurance, and taxes. (The cost of upkeep and insurance per co-op unit is usually less than that in similar dwellings. See notes 319,335 supra.) To be salable, however, the market value of the cooperative interest must be equal to those costs plus the related debt (the interest's pro-rata share of the unpaid mortgage).

346. See FisHER, op. cit. supra note 319, at 104. 
is less than his present assessment, he will be inhibited by his continued liability under the cooperative-apartment lease. ${ }^{347}$ This liability could be eliminated only in the event that the members of the cooperative agreed to terminate all of the leases and permit a mortgage default. ${ }^{348}$ Even absent such a liability, most cooperators would probably prefer increased assessments to the loss of their apartments, for emotional ties ${ }^{349}$ and the hope that real-estate values will improve tend to induce payment ${ }^{350}$-despite the fact that rational economics might suggest default. ${ }^{351}$ Nonetheless, default on the corporate mortgage may become inevitable as the remaining, over-assessed cooperators attempt to shoulder the cumulative weight of numerous delinquencies. The fatal pyramiding of arrearages is especially likely in those many cooperatives whose members, employed in the same or connected industries, are similarly affected by economic fluctuations. ${ }^{352}$

Subject as it is to a mortgage with a high loan-to-value ratio, the section 213 cooperative is especially susceptible to the dangers inherent in the members' financial interdependence. So long as a substantial portion of the co-op's debt remains unpaid, the value of the cooperative could rather promptly fall below the amount due on the mortgage and thereby cause the stock of insolvent cooperators to become unsalable. Accordingly, the FHA has established various regulations designed to protect the individual against his neighbors' insolvency, and to prevent a mortgage default by the cooperative corporation. Prospective cooperators must be approved by the FHA as to financial stability $;^{353}$ the corporation must maintain a reserve for contingencies $;^{354}$ leases,

347. See Note, 61 HARv. L. Rev. 1407, 1414 n.46 (1948).

348. On the legality of such action immediately prior to a default and the attendant appointment of a receiver, see $i d$. at $1415 \& \mathrm{n} .49$.

349. See Festinger, ScHaCter \& Back, op. cit. stipra note 319 , at 27 (25\% of people interviewed stressed congeniality of community as reason for being satisfied with their present home). Co-ops, in particular, stress community cohesivencss. See Proceedings, 1958 Cooperative Housing Conference 3, 64; 1950 House Hearings 151.

350. FisHeR, op. cit. supra note 319 , at $105 \mathrm{n} .15$ (noting persistence with which people hold on to their homes in the hope of recouping their equity investment).

351. Rationally, a buyer will default on a debt when it is secured by property which is not equal to the debt, and he has no personal liability. Often, however, homeowners refuse to follow such a path. See In the Matter of New York Title \& Mortgage Co., 277 N.Y. 66, 77, 13 N.E.2d 41, 43 (Sup. Ct. 1938): "It is general knowledge, too, that a landowner as often as not will protect his equity by keeping a mortgage good, even when he believes that the land on forced sale would produce less than the face amount of the lien." This same protective instinct would probably induce the cooperator to retain his apartment unit, even if the lease and the cooperator's liability thereunder had expired.

352. See McCullough, supra note 339, at 323. But cf. Teitelbaum, supra note 340 , at 422. Co-ops tend to have a high percentage of members who are engaged in one industry. See, e.g., Proceedrngs, 1958 Cooperative Housing Conference 40 (30\% membership in a single union).

353. FHA, Model Form of By-Laws, art. III, § 3(c) (Form No. 3244, 1957).

354. 24 C.F.R. $\$ 241.30$ (d) (Supp. 1958). The monthly additions to the reserve must be at least $3 \%$ of assessment charges for that period. FHA, Model Form of Certificate of Incorporation, art. VI, $\$ 2$ (Form No. 3234, Nov. 1957). 
and hence the cooperators' liability for assessments, may be limited to three years $; 355$ periodic inspections ensure that the corporation is maintaining the project in accordance with FHA standards. ${ }^{356}$ Also, although the statute would seem to limit occupancy to cooperators, the FHA may permit the corporation to rent apartments if stock in the co-op cannot be sold. ${ }^{357}$

These safeguards do not completely solve the problem of financial interdependence, however. Because they could not halt the snowballing of assessment delinquencies and super-assessments in a period of sharply receding realestate values, ${ }^{358}$ cooperators face a potential danger ${ }^{359}$ in this forbidding prospect.

\section{One Possible Answer: A Separate Fee For Each Unit}

One possible way to minimize the hazards of financial interdependence would be to issue, for each individual apartment, an absolute fee-simple title which would serve as security for each cooperator's separate mortgage loan. ${ }^{360}$ A given cooperator would thus be granted a "horizontal fee" to the area representing his apartment, and the common areas of the building could be held by all of the apartment owners in cotenancy. Proper upkeep of the individual fees could be assured through the use of cross covenants. Admittedly, the separate-fee approach has achieved its greatest success in European countries where special legislation specifically provides for the creation of such fees and describes in detail the rights and duties of the apartment owners. ${ }^{301}$ Nevertheless, experience in certain common-law jurisdictions indicates that, while

355. FHA, Model Form of Occupancy Agreenent (Form No. 3237, 1957). See also Ennis, Cooperative Housing I, N.Y. Times, Dec. 22, 1957, 8 (Real Estate), p. 1, cols. $5-6$, p. 4 , col. 4 ( $3 \frac{\pi}{2} / 2$ years is usual term).

356. FHA, Cooperative Housing Program, p. 13 (Form No. 3250, rev. 1957); 24 C.F.R. $\$ 241.30$ (b) (Supp. 1958).

357. Section 213 applies to "nonprofit cooperative ownership corporations . . . the permanent occupancy of the dwellings of which is restricted to members." Nevertheless, the FHA will permit the co-op to rent apartments under special circumstances. FHA, Cooperative Housing Program, p. 13 (Form No. 3250, rev. 1957). Its position is apparently based on the fact that the statute mentions only permanent occupancy.

358. See 1950 House Hearings 233 (questioning the value of the contingency reserve in case of a serious drop in real estate values).

359. Prospective cooperators are often warned about, 1954 Senate Hearings 982, and are known to worry about, the consequences of financial interdependence, see $1950 \mathrm{VA}$ AnN. ReP. 96; Ennis, Cooperative Housing I, N.Y. Times, Dec. 22, 1947, $\$ \&$ (Real Estate), p. 1, cols. 5-6, p. 4, col. 4. See also 1954 Senate Hearings 982.

360. See generally George, The Sale of Flats, 19 Convey. (n.s.) 3 (1955) ; Dickson, Freehold Title of Flats?, 28 L. Inst. J. 133 (1954) ; Note, 61 HARv. L. Rev. 1407, 1409$10 \mathrm{nn} .20$ \& 24, 1412 (1948). American commentators have tended to denounce the singlefee format as impossible and impracticable. See Issacs, supra note 336, at 208 (horizontal ownership impossible) ; Hennessey, supra note 340 , at 924 (describing complexity) ; Note, 61 HARv. L. REv. 1407, 1412-13 (1948).

361. Leyser, The Ozmership of Flats-A Comparative Study, 7 INT'L \& Cosr. L.Q. $31,37-50$ (1958). 
the creation of individual apartment fees requires careful draftsmanship, they can be effectively used to reduce the risks attending cooperator interdependence ${ }^{302}$ without the benefit of promotional legislation.

One criticism leveled against the separate-fee structure is that it relies heavily on technically complicated covenants running with the land. ${ }^{363}$ Under the common law, the owner of an upper-story apartment has no right to insist that lower-story apartment owners keep their walls in good repair so as to furnish support of the upper floors. ${ }^{364}$ Nor can an apartment owner, without specific grant, insist that his neighbors maintain their apartments so as to maximize the market for adjoining dwelling units. ${ }^{365}$ Protection of the individual cooperator's fee therefore depends upon maintenance covenants which, to be effective against subsequent transferors, must run with the land, that is, must fulfill the technical requirements of "privity," and "touching and concerning the land." 360 Privity would probably be established if the party originally owning the entire apartment building-ordinarily the sponsor-insisted that each purchaser of an individual unit (fee) covenant, on buying the fee, to maintain his property. ${ }^{367}$ As for the other requirement, a maintenance covenant undoubtedly would be deemed to touch and concern the land in every state except possibly New York. ${ }^{368}$ There, it might be construed as

362. Sale of individual apartment units is common in Scotland. Dickson, supra note 360, at 133. Although unusual in England, 21 Sol. 139 (1954), the separate-fee arrangement has been successfully employed where used. Leyser, supra note 361, at 51-52. In this country, the separate-fee approach was supported by the VA but, according to one author, has proved unsuccessful. See Hennessey, supra note 340 , at 24 n.3.

363. Ibid.

364. Jackson v. Bruns, 129 Iowa 616, 106 N.W. 1 (1906). Cf. Loring v. Bacon, 4 Mass. 574 (1808) ; Maddock v. Chase, 99 N.H. 241, 243, 51 A.2d 145, 147 (1947) (collecting cases). But cf. Graves v. Berdon, 26 N.Y. 498 (1863).

365. Mere diminishment of the market value of neighboring property is not justification for limiting a party's utilization of his property. White v. Bernhart, 41 Idaho 665,241 Pac. 367 (1925); Shepler v. Kansas Milling Co., $128 \mathrm{Kan} .554,278$ Pac. 757 (1929); Jubilee Yacht Club v. Gulf Ref. Co., 245 Mass. 60, 140 N.E. 280 (1923) ; Tarr v. Hopewell Community Club, 153 Wash. 214, 279 Pac. 594 (1929). An injunction is possible only when the activity is a nuisance. See McClosky v. Martin, 56 So. 2d 916 (Fla. 1951); George v. Goodovich, $288 \mathrm{~Pa}$. 48, 135 Atl. 719 (1927) ; Martin v. Williams, 141 W. Va. 595, 93 S.E.2d 835 (1956).

366. On the requirement of privity, see 3 TIFfany, Real Property $\$ 851 \& \mathrm{n} .23$ (3d ed. 1939) (collecting cases) ; 5 Restatmarent, Property $\$ \$ 542,547,548$ (1944). On touching and concerning the land, see 3 TIFFANY, op. cit. supra, $\$ 854$ \& nn.55-56 (collecting cases); Clark, Covenants and Interests Running with Land 94-100, 141, 172 (2d ed. 1947). If these elements are absent, the covenant will not run with the land even if the parties so state. Zanes v. Lehigh Valley Transit Co., 41 F.2d 552 (E.D. Pa. 1930) ; 3 TrFFANY, op. cit. supra, $\$ \$ 54$ n. 85 (collecting cases).

367. Such a covenant would comply with either of the two prominent definitions of privity. Clark, op. cit. supra note 366, at 111-21. But it would not comply with the Massachusetts doctrine of privity by way of tenure. See $i d$. at 128 .

368. See 3 TrFfaNY, op. cit. supra note $366, \S 854 \&$ nn.67, 79. 
personal, because of its affirmative form, and unrelated to the land. ${ }^{360}$ To circumvent this difficulty and the whole covenant problem as well, the original cooperators could be bound in their contracts of purchase to convey their apartment fees, subject to the individual mortgages, to a trustee corporation in return for stock. As part of this transaction, each cooperator would covenant personally with the corporation to maintain his property, and would grant the corporation a right of entry in case the covenant was breached. ${ }^{370}$ Subsequent purchasers of the apartment fee would therefore receive stock certificates the terms of which would include the corporation's outstanding right of entry in case of inadequate maintenance.

Another criticism of the individual fee springs from the facts that the cooperators as a group remain liable for the expense of maintaining the apartment building's common facilities; and that, while presently-used restrictions on the sale of cooperative-apartment stock constitute a legitimate method of ensuring that future cooperators are financially reliable, the same restrictions may illegally restrain the alienation of property when contained in a covenant. ${ }^{371}$ Even accepting the dubious assumption that covenanted restrictions limiting the eligible purchasers of an apartment fee would be invalid, ${ }^{372}$ this criticism of the separate-fee organization still lacks force. Since the expense of maintaining common facilities represents only a minor segment of the total cost of apartment ownership, ${ }^{373}$ the insolvency of one cooperator would not

369. See Miller v. Clary, 210 N.Y. 127, 103 N.E. 1114 (1913); 3 TrFsanY, op. cit. stupra note 366, $\$ 854 \&$ n.79 (Supp. 1957) (citing authorities and cases). Numerous exceptions to the New York rule have been created. Covenants to build fences, provide railroad crossings, and repair buildings have all been held to run with the land despite their affirmative form. See, e.g., Salvi v. John Manning Paper Co., 168 Misc. 661, 7 N.Y.S. $2 \mathrm{~d} 36$ (Sup. Ct. 1938) (covenant to maintain a dike). The Salvi court held, however, that its decision did not change the rule set forth in Miller v. Clary, and merely set up another exception to that rule.

In Neponsit Property Owners' Ass'n v. Emigrant Industrial Sav. Bank, 278 N.Y. 24, 15 N.E.2d 793 (1938), a covenant to pay an annual charge for maintenance and improvements of a real-estate development was held to run with each parcel conveyed. The operative covenants necessary to a single-fee cooperative would be similar to those upheld in Neponsit, and might fit under the exception created in that case.

370. See, e.g., Folsom, Land Without Earth: Freehold Flats in England, 14 CoNvex. (n.s.) 350, 354-56 (1950). Cf. VA, Multiple Unit Housing \$ 4(e) (Oct. 1, 1954).

371. See Note, 61 HaRv. L. Rev. 1407, 1410 (1948).

372. The cases upholding such restrictions on co-op stock seem to rely more on promoting the successful operation of co-ops than on the fact that a given restriction was, in form, placed on stock rather than real estate. See Penthouse Properties, Inc. v. 1158 Fifth Ave., Inc., 256 App. Div. 685, 11 N.Y.S.2d 417 (1939) ; cf. 68 Beacon St., Inc. v. Sohier, 289 Mass. 354, 194 N.E. 303 (1935). See also Note, 61 HARv. L. REv. 1407, 1410 \& n.24, 1417 n. .58 (1.948).

373. Interview with New York real estate agents, Nov. 28, 1958. Since the monthly mortgage payment includes taxes, insurance premiums, and interest, as well as repayment on the loan, it constitutes the bulk of the total housing cost. See generally 1957 Senate Hearings 856 (chart illustrating percentage of the monthly housing cost which constitutes payment on the debt and interest). 
impose a serious burden upon his neighbors holding individual fees and individual mortgages. In fact, the insolvent's property would probably be transferred by a mortgagee to a new owner who would quickly resume the payment of assessments. Moreover, as a preventive of insolvency, the FHA's power to reject prospective purchasers of cooperative stock on grounds of financial undependability might be extended to cover would-be purchasers of an individual fee. ${ }^{374}$

The only substantial disadvantages of separate-apartment fees and mortgages are that they aggravate the expense and delay involved in financing a co-op. ${ }^{375}$ Individual mortgages require more servicing and would probably carry an interest rate one-half of one per cent higher than a single-project mortgage on the same property. ${ }^{376}$ Also, a given builder would have to delay construction until a sufficient number of individual cooperators received mortgage commitments enabling them to provide him with adequate financing. In addition, the FHA, following its present policy, might require that ninety per cent of the apartment units be sold, and hence individually mortgaged, before construction. These difficulties suggest that the individually owned and mortgaged co-op is impractical-but not for the reasons usually stated.

\section{Still Another Answer: Assessment Insurance}

Financial interdependence would be eliminated without changing the co-op's present form of organization if the $\mathrm{FHA}$ insured the periodic assessments which are levied on each cooperator. Additional assessments would no longer have to be imposed upon solvent members because of another's default. Rather, the FHA would make good the defaulted assessment payments to the cooperative corporation over the duration of the mortgage, or pending the sale of the defaulter's interest, whichever period was shorter. The FHA's insurance liability need cover only those situations in which the defaulter was insolvent since, if he were not, overdue assessments could be collected through private legal action. Likewise, if the market value of his apartment were greater than future mortgage assessments thereon, it could be sold, and the FHA would not be liable for those assessments. Furthermore, the arrearage accruing prior to such a sale should not occasion reimbursement by the FHA

374. Of course, such action would only serve as an effective preventive during the life of the mortgage. Afterward, the mortgage is paid off, the insurance expires, and the co-op is no longer subject to FHA regulation.

375. Surprisingly, those commentators who have criticized the single-fee doctrine have generally overlooked these disadvantages, probably because they limited their analysis to legal problems. See authorities cited note 360 supra.

376. See authorities cited note 334 supra. Thus, the FHA authorizes a 5\% interest rate on separate mortgages for cooperatively-built single homes, as opposed to the $4 \frac{1}{2} \%$ rate on the single mortgage of a co-op. 67 Stat. 123 (1953), as amended, 12 U.S.C. $\$ 1715$ (e) (d) (Supp. V, 1958); 22 C.F.R. $\$ 241.11$ (Supp. 1958) (project mortgage must cover the entire property). 
unless it exceeds the cooperative's contingency reserve and any premiums received on the sale. 377

So defined, assessment insurance would not ordinarily increase the risks insured by the FHA beyond those presently covered under section 213 mortgage insurance. Provided cooperative and FHA practices remain unchanged, the proposed plan would merely impose on the FHA a definite responsibility for assessments corresponding to its present contingent mortgage-insurance liability. Cooperative rules forbidding the prepayment of individual assessments keep each member's debt-equity ratio constant, ${ }^{378}$ so that the percentage of debt to stated value on every apartment is the same. Moreover, periodic inspection by the FHA results in a standard level of maintenance, and prevents any unit in an apartment building from becoming worth substantially less than another because of greater deterioration. ${ }^{379}$ Fluctuations in the value of all a building's units—or in the stock interests representing them-should, therefore, be proportionately uniform. And since the value of the building is equal to that of all its units, the market value of an individual unit in relation to its pro-rata share of the mortgage debt should, at any one time, yield the same ratio as the market value of the entire building in relation to the corporate mortgage. Hence, when FHA liability for future assessments arises under the proposed insurance scheme, that is, when an insolvent defaulter's apartment unit is worth less than his share of the unpaid mortgage and is therefore presently unsalable, ${ }^{380}$ the value of the building will be less than the unpaid balance of its corporate mortgage. In this situation, the FHA has a contingent mortgage-insurance liability under present law: if a corporate default occurred, the FHA would have to bear a loss equal to the difference between the outstanding mortgage balance and the market value of the secured property (the apartment building). ${ }^{381}$

Since assessment insurance would ordinarily necessitate payments by the FHA only when a contingent mortgage-insurance liability already existed, the effect of assessment insurance would usually be to advance the assumption of a future FHA liability. True, the insolvency of a few cooperators rarely results in an immediate corporate default, because solvent members pay the defaulters' assessments in order to keep their own apartments. Eventually, however, the additional payments may cause more insolvencies leading to a

377. Assessment-insurance liability would ordinarily arise only when the apartment unit was unsalable, its market value being less than the total of future mortgage assessments. See note 349 supra.

378. See Ennis, Cooperative Housing II, N.Y. Times, Dec. 29, 1957, \& \& (Real Estate), p. 1 , col. 6 , p. 2 , col. 8 (individuals may not prepay their portions of the total mortgage).

379. See note 356 supra.

380. See generally 1957 House Hearings 676 . This statement assumes that the building is being evaluated as an apartment and not in relation to other possible uses such as a hotel.

381. See 67 Stat. 123 (1954), as amended, 12 U.S.C. $\$ 1715 e(e)$ (Supp. V, 1958), incorporating 66 Stat. 603 (1952), 12 U.S.C. $\$ 1713(\mathrm{~g})$ (1952). 
mortgage default, and the FHA's mortgage-insurance liability would then cease to be contingent. Undeniably, therefore, the proposed insurance would forestall corporate defaults by relieving the solvent cooperators of the insolvent cooperators' assessments. In fact, assessment insurance might lessen the FHA's losses, for the cost of assuming individual assessments would normally be less than the FHA liability following a default on the corporate mortgage. The FHA could also rent out the apartments of individual delinquents and thereby reduce its payments to less than the full assessment. And, of course, as the mortgage debt is reduced-or if the building's market value rises-a defaulter's apartment unit might become salable, thus terminating the FHA's assessment payments short of the life of the mortgage.

In a few instances, the proposed insurance could increase FHA liability, since a member's insolvency will not precipitate a default on the corporate mortgage-even when his apartment is unsalable-if the remaining members are able to carry his assessments until mortgage retirement. And, absent a corporate mortgage default, the FHA could not incur liability under the present section 213. Nonetheless, despite the increased FHA expense, assessment insurance is justified in this situation. Once the Government undertakes to insure cooperative-apartment mortgages, it should follow the policy of other federal insurance programs and bear the full risk involved. As matters stand, the Government can rely on the solvent cooperators' assumption of insolvent cooperator assessments to shield the FHA from liability. Only if the FHA is made responsible for individual delinquencies through assessment insurance will the entire risk of a mortgage default be placed on the only party who should bear it, the insurer. ${ }^{382}$

If adopted, however, assessment insurance would pose certain administrative problems. During a serious depression, mass cooperator defaults could occur despite the assumption of assessments by the FHA, for cooperators, though relieved of extra assessments, can still become insolvent. The Commissioner of the FHA might be authorized, therefore, to discontinue government assessment payments, and thus to force a more immediate default, whenever widespread insolvency makes default on the corporate mortgage appear inevitable. He would then have to balance the possible economy-priming effect of continued assessment-insurance payments against the fact that, when realestate values are falling, prompt foreclosure would lessen the FHA's impending loss under section 213 mortgage insurance. ${ }^{383}$

Assessment insurance would also raise two lesser problems. First, FHA record-keeping would be increased. But this increase would not appear to warrant an additional insurance charge, inasmuch as the current 0.5 per cent

382. See generally 1958 Senate Hearings 583, 764 (terms of co-op insurance should be on a par with those under other programs).

383. For a proposal that the FHA impose a moratorium in times of serious depression, see Business Week, Oct. 17, 1953, p. 186; Abrams, U.S. Housing: A New Program, New Leader, Jan. 13, 1958, p. S. But see 1958 House Hearings 255 (opposing such action). 
rate is the same as that charged under the FHA program for insuring mortgages on single homes-a program which involves no less servicing than would assessment insurance. ${ }^{384}$ The second problem is that insurance benefits would have to be paid in cash rather than debentures in order that a cooperative corporation be able to apply FHA payments against its mortgage. The utilization of debentures under the Housing Act has been criticized generally, ${ }^{355}$ however, and an exception in the case of assessment insurance seems justified by the possibility that the insurance may actually lessen the FHA's overall losses.

\section{The Cooperator's Rights and Powers}

Although cooperators are in a better position to determine operational policies than the stockholders of the average corporation owned by hundreds of individuals, they lack the competence to direct a large project by themselves. ${ }^{386}$ Their inexperience, factional disputes, and failure to evict delinquent tenants promptly ${ }^{387}$ have, in the larger cooperatives, usually necessitated the employment of professional managers. 388

During the 1920's, the absence of adequate cooperator control over pro-

384. See 24 C.F.R. $\$ 222.2$ (a) (1) (2) (Supp. 1958). The $0.5 \%$ rate has been criticized as excessive even when applied to mortgages on single homes. Stern, New Plans Sought for Home Loans, N.Y. Times, July 21, 1957, \& 8 (Real Estate), p. 1, col. \&. As anplied to $\$ 213$, it has netted the FHA $\$ 8$ million. 1958 Senate Hearings 581. Proposals have been made to place $\S 213$ mortgages under a mutual-insurance fund, similar to that employed under $\$ 203$, which would enable mortgagors to receive refunds on excessive premiums. $I d$. at $581-84$.

In contrast to the FHA, the VA makes no charges for mortgage guarantees. 1957 House Hearings on Veterans' Affairs 243.

385. Hearings on Independent Offices Appropriations for 1958 Before a Subcommiltec of the House Committee on Appropriations, 85th Cong., 1st Sess. 1775-76 (1957).

386. Proceedings, 1958 Cooperative Houstng Conference 95. The number of cooperators in a $\$ 213$ co-op may be over one thousand. See, e.g., Ennis, Co-op Tenants Sut Project Builder, N.Y. Times, Dec. 1, 1957, \$ \& (Real Estate), p. 1, col. \&. (Clearview Co-op in New York City, 1,778 families); N.Y. Times, Aug. 4, 1958, p. 1, col. \& (Jackson Heights Co-op, 1,122 families).

387. Note, 61 Harv. L. Rev. 1407, 1409 n.16 (1948) ; Staff of Subconrm. on Housing \& Rents, Senate Comar. on Banking \& Currency, 81st Cona., 20 Sess., Report on Domestic Cooperative Housing 15-16 (1950) (citing factional disputes); Abrams, supra note 383, at 8; Parker, Cooperative Housing, Mid-1950, 73 Monthly Lab. Rev. 258, 264 (1951). On the role of the managing agent, see Teitelbaum, Representing the Purchaser of a Cooperative Apartment, 45 ILL. B.J. 420, 423 (1957).

388. See Ennis, Cooperative Housing I, N.Y. Times, Dec. 22, 1957, \& 8 (Real Estate), p. 1, cols. 5-6 (referring to publication issued by managing agent of a number of New York cooperatives); Flexner, Cooperative Housing in the United States, Construction Rev., June 1958, p. 4, at 4, 5, 9; Co-op Activity \& Housing News, May 1958, p. 5 (advertisement for two major management companies); $i d$. ., p. 5, col. 2 (Presidential Management Corp. services 20 projects). For an example of the services offered by one management firm, see Brett, Wyckoff, Potter, Hamitton, Ince, The Cooperative Apartiment HOUSE 22-23 (1957). 
fessional managers sometimes resulted in misconduct and fraud. ${ }^{389}$ Accordingly, the FHA has required that all cooperative by-laws leave major policy decisions to the cooperators or their elected representatives. ${ }^{390}$ To safeguard the cooperators' control, the FHA has also imposed specific restrictions on management activity. Thus, the managing agent must be approved by, and file periodic reports with, the FHA,, ${ }^{391}$ post fidelity bonds, ${ }^{392}$ and keep the corporate books in accordance with a prescribed accounting system. ${ }^{393} \mathrm{He}$ may not take loans from the corporation, ${ }^{394}$ and his fees are limited to an amount meeting with FHA approval. ${ }^{395}$ Although, to date, the size of the FHA staff has been inadequate to supervise cooperative management properly, ${ }^{396}$ the FHA's regulations should prove effective once Congress appropriates enough funds for their stringent enforcement.

\section{Preventing Abuses by the Directors and the Cooperators}

The FHA's restrictions on management and its model by-law provisions serve to vest the power to determine cooperative operational policy in a board of directors. ${ }^{397}$ Often cooperators themselves, the directors are elected by the cooperators, each having one vote regardless of the size of his apartment. ${ }^{398}$ To ensure genuine representation, the FHA forbids proxy voting ${ }^{390}$-a de-

389. Schaffer v. 8100 Jefferson Ave. E. Corp., 267 Mich. 437, 255 N.W. 324 (1934). See McCullough, supra note 339, at 324-25 $\mathrm{nn} .50-52$ (citing cases on management misconduct).

390. See, e.g., powers of directors in FHA, Model Form of Certificate of Incorporation, art. V (Form No. 3234, 1957) ; FHA, Model Form of By-Laws, art. IV-VI (Form No. 3244, 1957) ; FHA, Model Form of Managennent Agreement, clauses F, H (Form No. 3238, 1955).

391. On the approval requirement, see Proceedings, 1.958 Cooperative Housing Conference 50; H \& HFA-FHA, Legal Reouirearents in the Closing of Section 213 Managemient and Sales Type Projects Involving Insurance of Advances 12 (March 1, 1957) ; 24 C.F.R. $\$ 241.6$ (Supp. 1958). On the requirement of periodic reports, see 24 C.F.R. $\$ 241.30$ (g) (Supp. 1958).

392. FHA, Model Form of By-Lawes, art. V, $\$ 12$ (Form No. 3244, 1.957).

393. FHA, Model Form of Certificate of Incorporation, art. VII, $\S 6$ (Form No. 3234, 1957) ; 24 C.F.R. $\$ 241.30$ (g) (Supp. 1958).

394. FHA, Model Form of Certificate of Incorporation, art. VII, 3 (Form No. 3234, 1957) ; 24 C.F.R. \$ 241.30 (a) (Supp. 1958).

395. Ibid.

396. Procendngs, 1958 Cooperative Housing Conference 48; H.R. Rep. No. 2963, 84th Cong., 2d Sess. 32, 55-56 (1956).

397. See generally FHA, Model Form of Certificate of Incorporation, arts. IV, V (Form No. 3234, Nov. 1957); Proceedings, 1958 Cooperattve Housing Conference 50; Issacs, To Buy or Not to Buy: That is the Question . . . What is a Cooperative Apartmont?, 13 RECORD of N.Y.C.B.A. 203 (1958).

398. Ennis, Coopcrative Housing I, N.Y. Times, Dec. 22, 1957, \& 8 (Real Estate), p. 1, cols. $4-5$ (directors are often members themselves); FHA, Model Form of Information Bulletin (Form No. 3241, Nov. 1957) (one vote per member).

399. H \& HFA-FHA, Legal Requirearents in the Closing of Section 213 MaNagement and Sales Type Projects Involving Insurance Upon Completion 6 (May 
vice often manipulated in widely-held corporations to achieve continued reelection of the same directors. ${ }^{400}$ Nevertheless, despite the FHA's regulations, the typical cooperator shows little interest in managerial problems. ${ }^{401}$

While a combination of FHA controls and accountability to its electorate will probably prevent a board of directors from acting in a manner which would injure the cooperative as a whole, ${ }^{402}$ arbitrary action harmful to particular, individual cooperators is possible, if not likely. The directors are empowered to make and interpret rules pertaining to the use of the premises. ${ }^{403} \mathrm{~A}$ cooperator's failure to abide by the rules constitutes an automatic default which, if not cured to the corporation's satisfaction within thirty days, entitles the corporation to a right of entry enforceable by a summary action to dispossess. ${ }^{404}$ If in fact predicated upon a serious violation rather than animosity toward an individual who failed to observe an insignificant rule, expulsion is a legitimate remedy-provided the cooperator is fairly compensated for his interest in the cooperative. ${ }^{40.5}$ Safeguards are needed, however, to preclude a discriminatory exercise of the directors' power resulting in the dispossession of an unpopular cooperator who happens to violate a minor occupancy regulation. ${ }^{406}$ The courts cannot be relied on to correct such abuses,

$1,1957)$ ("if proxy voting is permissible a member may appoint only his or her spouse as the proxy"); 1957 House Hearings 675 .

400. See Baker \& Cary, Corporattons 159-66 (3d ed. 1958), citing Berle \& Mreans, The Modern Corporatton and Private Property (1932).

401. Proceedings, 1958 Cooperative Housing Conference 47-51. See, e.g., Nostrand Gardens, Inc. v. Roche, N.Y.L.J., June 20, 1957, p. 7 (N.Y. Sup. Ct., June 19, 1958) (only 150 out of 300 cooperators attended the first meeting).

402. E.g., the FHA prohibits directors from increasing assessments without agency approval. See generally 24 C.F.R. $\$ 241.29$ (Supp. 1958) ; FHA, Model Form of Certificate of Incorporation, art. VII, $\$ 2$ (Form No. 3234, Nov. 1957) (illustrating other FHA restrictions on directors' powers).

403. FHA, Model Form of By-Lazes, art. V (Form No. 3244, Nov. 1957).

404. FHA, Model Form of Occupancy Agreement (Section 213), art. 13 (Form No. 3237, Nov. 1957) ; Letter from Joseph Nardone, Director, FHA, New York City Office, to the Yale Law Journal, Feb. 17, 1958, on file in Yale Law Library. The provision for summary dispossession does not exclude the utilization of other remedies. Smith v. Detroit Loan and Bldg. Ass'n, 115 Mich. 340, 73 N.W. 395 (1897) ; Crosby v. Jarvis, 46 Misc. 436, 92 N.Y. Supp. 229 (Sup. Ct. 1905).

405. Art. III, $\S 6$ of the Model By-Laws, supra note 403, provides for compensation. But expulsion will be upheld only if the compensation is reasonably computed. Cf. 5 CoRBIN, CoNTRACTs $\$ \$ 1054,1057$ (1951) (damage clauses which serve to impose a penalty are generally prohibited) ; Hennessey, Co-operative Apartments and Toun Houses, 1956 ILL. L.F. 22, 37-38 (advocating a reasonable forfeiture). See also Vernon Manor Co-op Apartments v. Salantino, N.Y.L.J., July 15, 1958 (N.Y. Sup. Ct., July 14, 1958) (\$2 fine for failure to pay $\$ 2$ monthly charge held unreasonable).

406. The possibility of such arbitrary action is not remote. The Nostrand Co-op in New York City has announced that it will deny a member's option to move into a larger unit if he is "uncooperative," that term being defined as "destructive or bothersome actions 
because a lawsuit would be too costly, time-consuming, and unlikely to succeed. Although the judiciary has expressed a general dislike for forfeiture clauses, ${ }^{407}$ it often feels bound to enforce the strict letter of a property agreement specifically sanctioning forfeiture. ${ }^{408}$

One suggested remedy is to grant every expelled member a right to appeal the directors' decision to the membership at large. ${ }^{409}$ But cooperator apathy, plus the fact that the general membership is as likely to harbor animosities toward an individual member as is the board of directors, would tend to reduce an appeal of this sort to an empty gesture. Preferably, the FHA should insist that expelled members have the right to appeal the board's determination to an independent arbitrator, who would base his decision solely on the nature of the alleged violation. ${ }^{410}$

The individual must also be protected from unfair action by his fellow cooperators. In the absence of a special charter or by-law provision, the sale of all of the corporate assets can ordinarily be effected by a majority or twothirds cooperator vote (varying with state law). 411 Thus, a significant portion of the cooperators may have to give up their apartments involuntarily because others desire to make a profit on the sale of the entire building. ${ }^{412}$ To date,

of stockholders or their children; unreasonable boycotting of income producing machines; failure to attend meetings or to vote at election time." See Co-op Activity \& Housing News, May 1958, p. 5, col. 3.

407. E.g., Murphy v. Traynor, 110 Colo. 466, 135 P.2d 230 (1943) ; Warren v. Driscoll, 186 Minn. 1, 242 N.W. 346 (1932) ; Dodier Realty \& Investment Co. v. St. Louis Nat'1 Baseball Club, Inc., 361 Mo. 981, 238 S.W.2d 321 (1951).

408. E.g., O'Byrne v. Jebeles and Colias Confectionery Co., 165 Ala. 183, 51 So. 633 (1910) ; 7039 Wentworth Ave. Bldg. Corp. v. Trough, 332 Ill. App. 635, 76 N.E.2d 350 (1947) (upholding forfeiture based on covenant against keeping pets) ; Blue Ridge Coal Co. v. Hurst, 196 Ky. 432, 244 S.W. 892 (1922) ; Moyer v. Mitchell, 53 Md. 171 (1880).

409. Yourman, Some Legal Aspects of Cooperative Housing, 12 LAW \& Contearp. Рвов. 126, 132-33 (1947).

410. Arbitration would save time and money. See, e.g., Joseph F. Millelman Corp. v. Murray L. Spies Corp., 205 Misc. 1017, 129 N.Y.S.2d S22 (1954) (dictum) ; Franklin v. Goldstone Agency, 33 Cal. 2d 628, 188 P.2d 60 (1949) (dictum).

411. See, e.g., N.Y. Stock Corp. Law \$ 20; N.Y. Membership Corp. Law \$ 21; Oleck, Non-Proftt Corporations and Assoctations 255 (1958). See also Note, 67 YALE L.J. 1288, 1289 n.5 (1957).

412. It is unlikely that cooperators are presently aware of the danger.

The ignorance of purchasers of cooperative apartments of this important fact [that the cost of their apartment is not only the amount paid for the stock but also future mortgage payments] has made possible many fraudulent schemes for the sale of cooperative apartments and has induced many persons to buy cooperative apartments who, were they aware of the full price they were paying, would not have bought.

Issacs, To Buy or Not to Buy: That is the Question . . . What is a Cooperative Apartment?, 13 ReCoRd of N.Y.C.B.A. 203, 225 (1958). 
the FHA has taken no stand on this issue. It should be resolved by the members, but at the time when the cooperative is originally organized. If the members then wish to protect their apartments rather than abide by majority rule in this respect, a clause should be inserted in the articles of incorporation requiring unanimous or near-unanimous approval for the sale of the entire building. On the other hand, if the cooperators are satisfied with the vote prescribed by state law, this fact should be affirmatively stated in the corporation's articles and the FHA-approved information bulletin so that future cooperators will be aware of their position.

\section{Sale of Individual Apartments}

The most severe restriction placed upon the individual cooperator by section 213 is that it eliminates the individual homeowner's traditional privilege of profiting on the sale of his dwelling if he can. ${ }^{413}$ Under the FHA model by-laws and occupancy agreement, a cooperator desiring to sell his stock must first offer it to the corporation at book value. Only if the corporation refuses to act on its purchase option may "the member ... sell his stock to any person who has been duly approved by the corporation as a member."114 In effect, these provisions limit the cooperator to losing money or breaking even on the sale of his dwelling. If the stock is worth more than the owner's equity interest in the cooperative-the book value-the corporation will exercise its option and later make a profit on resale. ${ }^{415}$ This denial of the cooperator's opportunity to profit has been justified as drawing home-seekers, not speculators, to the co-op. ${ }^{416}$ This objective is achieved more simply and less harshly by the present statutory requirement that every cooperator reside in the apartment represented by his stock, a requirement that should forestall stock purchases designed primarily for speculation. ${ }^{\mathbf{4 1 7}}$

413. 1950 House Hearings 71.

414. FHA, Model Form of By-Lazes, art. III, $\S 5$ (Form No. 3244, 1957) ; FHA, Model Form of Occupancy Agreement, art. VIII (Form No. 3237, 1957). Although the FHA model form calls for an option price of book value, some $\$ 213$ cooperatives apparently have used par value. See N.Y. Times, Jan. 4, 1959, \& \& (Real Estate), p. 1, col. \&, p. 2, cols. 5-6.

415. See 1957 Senate Hearings 675. But see U.S. Buread of LAzor Statistics, Dep't of Labor, Bull. No. 896, Nonprofit Housing Projects in the United States 4 (1947) ("In some cases ... the association had no funds with which to redeem the member's equity.").

416. See 1958 Honse Hearings 676; 1950 House Hearings 971; REPORT oN DoMrstic Cooperative Housing, op. cit. supra note 387, at 23; Wood, Recent Trends in AMrerican Housing 172 (1931).

417. See 64 Stat. 54 (1950), as amended, 12 U.S.C. $\S 1715$ (e) (a) (i) (1952). See also Issacs, supra note 412, at 211-13. A true speculator could not afford to deal in one apartment at a time, which would be necessary if he had to reside in every apartment he owned. 
Even if the corporate option were eliminated, the cooperator still might be unable to sell his apartment at the best price if the corporation abused its power to reject prospective purchasers. ${ }^{418}$ Courts have enforced this powerdespite the fact that its exercise restricts the alienability of property ${ }^{419}$ because of the financial interdependence of cooperators and their special need for harmonious relations. ${ }^{420}$ In view of this judicial rationale, the burden should be on the corporation to demonstrate that either of these grounds was the basis of its rejection of a prospective member. Once the FHA has passed on the financial responsibility of prospective members, rejection on that ground will usually be difficult to defend. ${ }^{421}$ As for future harmony among the members, the cooperative should have to show that a rejected applicant has a definite history of poorly maintaining property or failing to get along with his neighbors. ${ }^{422}$ Since the validity of the corporation's refusal should be

418. This power is usually vested in the directors. See Ennis, Cooperative Housing I, N.Y. Times, Dec. $22,1957, \S \&$ (Real Estate), p. 1, cols. 4-5. The turnover ratio in $\S 213$ co-ops so far has been approximately 5\%. Ennis, Revision to Curb Abuses in Co-ops, N.Y. Times, Dec. 8, 1957, p. 1, col. 7, p. 6, col. 7.

419. All restrictions on the alienation of property are not illegal. "Each case must be thoroughly examined in the light of all the circumstances to determine whether the objective sought to be accomplished by the restraint is worth attaining at the cost of interfering with the freedom of alienation." Restatesrent, Property $\$ 406$, comment $i$, at 2407 (1944) ; Manning, The Development of Restraints on Alienation Since Gray, 48 Harv. L. Rev. 373, 399 (1935).

420. Penthouse Properties, Inc. v. 1158 Fifth Ave., Inc., 256 App. Div. 685, 691, 11 N.Y.S.2d 417, 422 (1939) ; 68 Beacon St. v. Sohier, 289 Mass. 354, 194 N.E. 303 (1935); Note, 49 Harv. L. Rev. 158 (1935).

Members of a cooperative live in the same proximity to each other as do ordinary apartment dwellers, but, having invested in the security of a home, they are usually unwilling and often unable to move away from an infiltration of unpopular neighbors. In many cases, moreover, participants in a cooperative backed by a labor union or veterans' organization may find restraints necessary to prevent the intrusion of those who are not members of the special group for the benefit of which the apartment was built and the risks assumed.

Note, 61 HARv. L. REv. 1407, 1416 (1948).

421. Although financial interdependence is an important factor, see text at notes 352 59 supra, $\$ 213$ cooperatives fail to guarantee absolute protection against financially unstable members. If a cooperator dies, his heirs can acquire his interest. FHA, Model Form of By-Lazes, art. III, $\$ 5$ (Form No. 3244, 1957); FHA, Model Form of Occupancy Agrecment, art. 8(a) (Form No. 3237, 1957). Apparently, FHA approval of the heirs as members is not necessary, since the FHA By-Lawes only require approval of applicants (art. III(e)) and not heirs. Thus, an impecunious heir might become a member of a cooperative. 1165 Fifth Ave. Corp. v. Alger, 288 N.Y. 67, 41 N.E.2d 461 (1942) (dictum).

422. Cooperatives have exhibited a willingness to reject prospective cooperators for much less substantial grounds. The Nostrand Co-op will by-pass prospective cooperators who "refuse to serve the general community in some capacity, or are not oriented to benefit the co-op according to their capacity." Co-op Activity \& Housing News, May 1958, p. 5, col. 4 . 
determined as quickly as possible, a by-law might profitably provide for arbitration of this issue.

\section{APPENDIX}

The following materials are cited throughout this Comment as here indicated.

Hearings on Varions Bills to Amend the Federal Housing Lazes Before a Subcommittee of the Senate Committee on Banking and Currency, 85th Cong., 2d Sess. (1958), are cited as 1958 Senate Hearings.

Hearings on the Housing Act of 1958 Before the Subcommittee On Housing of the House Committee on Banking and Currency, 85th Cong., 2d Sess. (1958), are cited as 1958 House Hearings.

Hearings on H.R. 1917, 7840, 9719, 9729, 9744, 10065, 10131, 10166, 10331, 10333, 10477, $10480,10696,10764,11015,11051,11109,11136,11290,11384,11436,11505,11597 \mathrm{Be}-$ fore the House Committee on Veterans' Affairs, 85th Cong., 2d Sess. (1958), are cited as 1958 House Hearings on Veterans' Affairs.

Hearings on Various Bills to Amend the Federal Housing Lazos, and Other Bills, Before A Subcommittee of the Senate Committee an Banking and Currency, 85th Cong., 1st Sess. (1957), are cited as 1957 Senate Hearings.

Hearings on the Housing Act of 1957 Before the Subcommittee on Housing of the House Committee on Banking and Currency, 85th Cong., 1st Sess. (1957), are cited as 1957 House Hearings.

Hearings on H.R. 21, 59, 60, 1263, 2236, 2560, 2581, 3074, 3807, 3857, 4556, 4602, 4605, 4606 Before the House Committee on Veterans' Affairs, 85th Cong., 1st Sess. (1957), are cited as 1957 House Hearings on Veterans' Affairs.

Hearings on Various Bills to Amend the Federal Housing Laws, and Other Bills Before a Subcommittee of the Senate Committee on Banking and Currency, 84th Cong,, 2d Sess. (1956), are cited as 1956 Sentate Hearings.

Hearings on H.R. 10157 Before the House Committee on Banking and Currency, 84th Cong., 2d Sess. (1956), are cited as 1956 House Hearings.

Hearings on S. 789, S. 1022, S. 1412, S. 1501, S. 1524, S. 1565, S. 1642, S. 1744, S. 1766, and $S .1800$ Before $A$ Subcommittee of the Senate Committee on Banking and Currency, 84th Cong., 1st Sess. (1955), are cited as 1955 Senate Hearings.

Hearings on H.R. 5827 (Superseded by S. 2126) Before the House Committce on Banking and Currency, 84th Cong., 1st Sess. (1955), are cited as 1955 House Hearings.

Hearings on S. 2889, S. 2938, and S. 2949 Before the Senate Committee on Banking and Currency, 83d Cong., 2d Sess. (1954), are cited as 1954 Sentate Hearings.

Hearings on H.R. 6618 and H.R. 6742 (Superseded by H.R. 7402) Before the House Committee on Banking and Currency, 81st Cong., 2d Sess. (1950), are cited as 1950 House Hearings.

Hearings on H.R. 5631 Before the House Committee on Banking and Currency, 81st Cong., 1st Sess. (1949), are cited as 1949 House Hearings.

Hearings on Perfecting Amendments to S. 866, Before the Senate Committee on Banking and Currency, 80th Cong., 2d Sess. (1948), are cited as 1948 Senate Hearings.

Hearings on S. 866 Before the House Committee on Banking and Currency, S0th Cong., 2d Sess. (1948), are cited as 1948 House Hearings.

N.Y. State Housing Comm'r, Report on Pension Funds and Housing Investment 
(March 15, 1956), reprinted in 1956 Senate Hearings 470, is cited as 1956 REPORT OF N.Y. Housing Comm'r.

National Housing Conference, National Ass'N of Housing and Redevelopment Offictals, \& Cooperative League of the U.S.A., Proceedings, First Nat'i Conference on Cooperative Housing (March 11-12, 1958), are cited as Proceedings, 1958 CooperaTIVE Housing CONFERENCE. 